\title{
Ян Сатуновский
}

\section{Рубленая проза}

\section{Собрание стихотворений}

\section{Verlag Otto Sagner München · Berlin - Washington D.C.}

Digitalisiert im Rahmen der Kooperation mit dem DFG-Projekt „Digi20“

der Bayerischen Staatsbibliothek, München. OCR-Bearbeitung und Erstellung des eBooks durch den Verlag Otto Sagner:

http://verlag.kubon-sagner.de

( ) bei Verlag Otto Sagner. Eine Verwertung oder Weitergabe der Texte und Abbildungen, insbesondere durch Vervielfältigung, ist ohne vorherige schriftliche Genehmigung des Verlages unzulässig. 


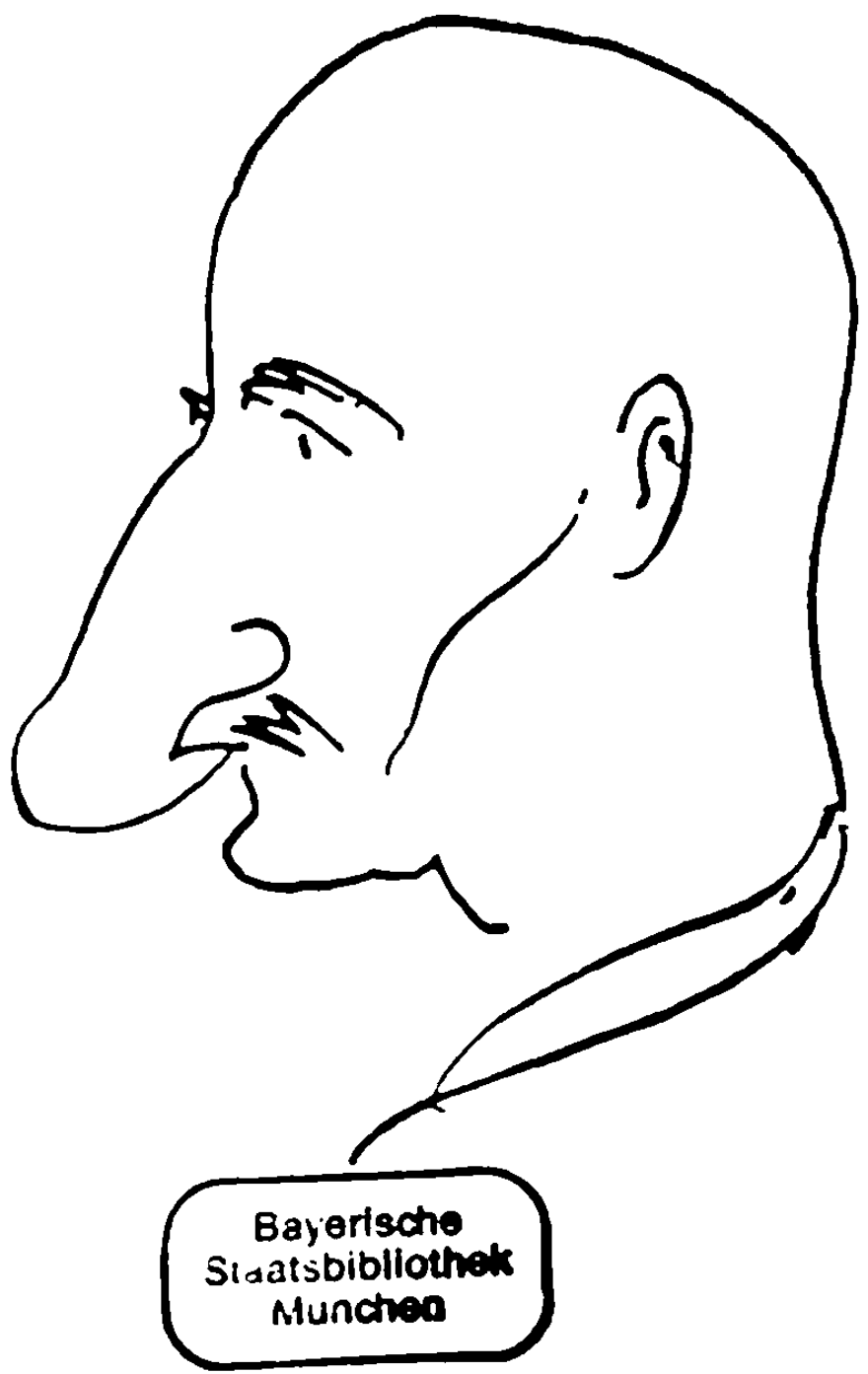

Ян Сатуновский.

Автошарж. 1966 год. 
ARBEITEN UND TEXTE ZUR SLAVISTIK · 58 HERAUSGEGEBEN VON WOLFGANG KASACK

\section{ЯН САТУНОВСКИЙ}

\section{РУБЛЕНАЯ ПРОЗА}

Собрание стихотворений

Составление, подготовка текста и предисловие Вольфганга Казака

Послесловие Геннадия Айги

\section{4}

München. Verlag Otto Sagner in Kommission 
Jan Satunovskij (1913-1982) ist einer der bedeutendsten Vertreter der russischen "Zweiten Kultur", jener Kultur, die in der Zeit der Herrschaft der Sowjetliteratur auf jede innere und äußere Anpassung an das von der Kommunistischen Partei Gewünschte verzichtete, ihr eigentliches Schaffen nicht publizieren konnte und nur in einem kleinen Kreis bekannt wurde. Diese Ausgabe erfaBt das dichterische Schaffen Satunovskijs so vollständig wie möglich. Sie wurde 1979 von Gennadij Ajgi und dem Autor angeregt, lieb sich aber erst 1993/94 mit Hilfe von Studenten der Universität zu Köln verwirklichen. 1993 stellte der Bruder des Autors weitere Texte zur Verfügung. Das Buch enthält eine vom Autor getippte dreibändige Samizdat Ausgabe und in chronologischer Reihenfolge alle handschriftlich und gedruckt erhaltenen Gedichte.

W.K.

Die Deutsche Bibliothek - CIP-Einheitsaufnahme

\author{
Satunovekij, Jan: \\ Rublenaja proza : sobranie stichotvorenij / Jan Satunovskij. \\ Sost., podgot. teksta i predisl. Vol'fganga Kazaka. Poslesl. \\ Gennadija Ajgi. - München : Sagner, 1994 \\ (Arbeiten und Texte zur Slavistik ; 58) \\ ISBN 3-87690-548-6 \\ NE: GT
}

Alle Rechte vorbehalten

ISSN 0173-2307

ISBN 3-87690-548-6

Gesamtherstellung Kleikamp Druck GmbH, Köln

Gedruckt auf chlorfrei gebleichtem Papier 


\section{Содержание}

Вольфганг Казак, „Стихи из неглавных слов“

Предисловие

Краткая автобиография 1979 г.

Избранное, составленное автором. Самиздат 1974

Первый том

Второй том

58

Третий том

„Стихи из нег лавных слов"

Геннадиһ Аһ̆ги, Летопись всеӐ нашеӐ хизни

О поэзин Яна Сатуновского. Послесловие

\section{Прилохения}

Библиография публикаций Сатуновского

Реестр первых строк по альфабиту

\section{Илльстрацин}
Автошарж
Фотография
Рухопись краткой автобиографии 1979 r.
Фотография
Рукопись стихотворений 


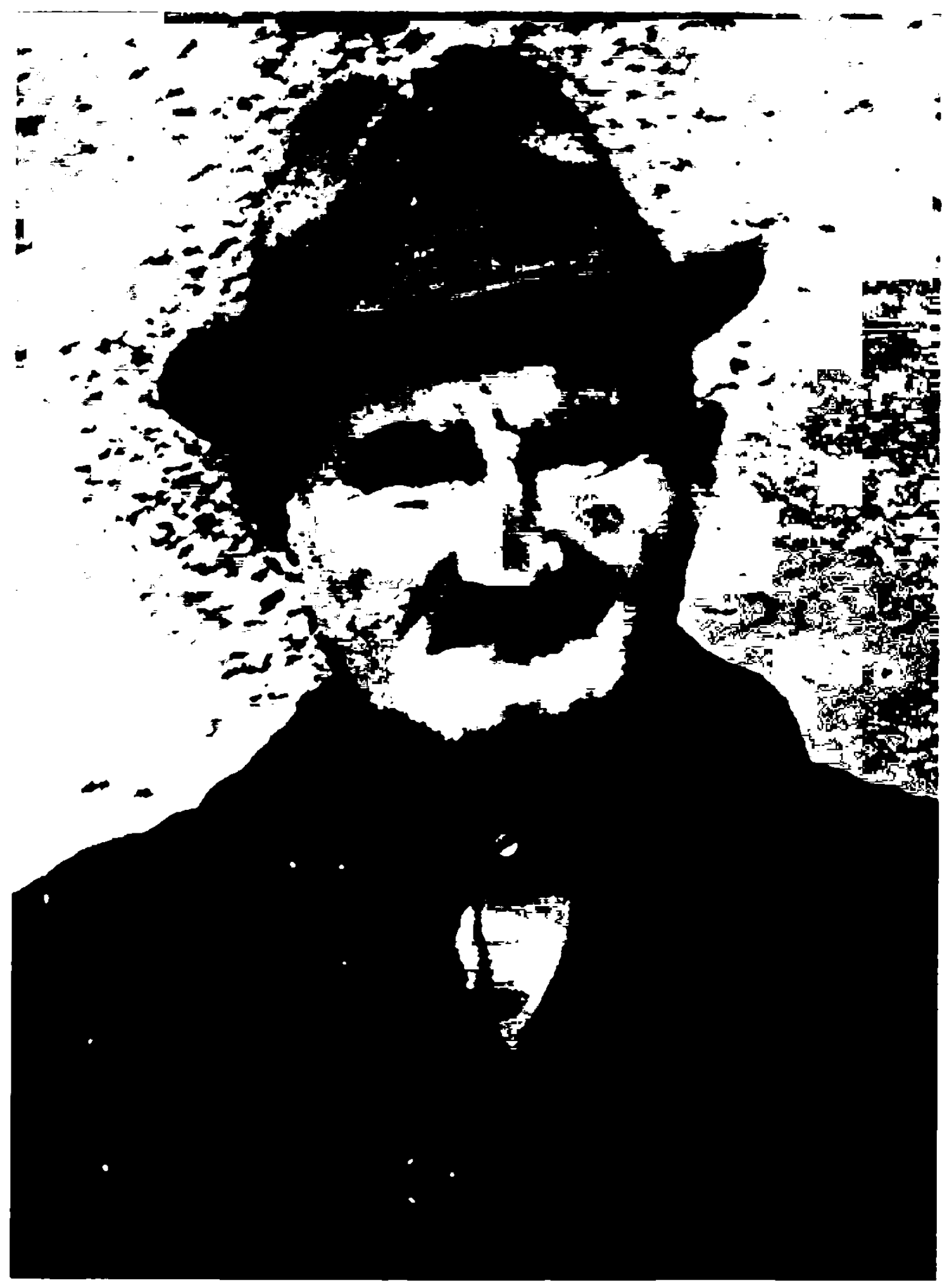




\section{- СТИХИ ИЗ НЕГЛАВНЫХ СЛОВ *}

\section{Предисловие}

Ян Сатуновский - автор русского самиздата. Он написал свои стихотворения, свою „рубленую прозу“, как он назвал их в одном из своих кратких и илотных текстов, или свои „стихи из пеглавных слов“ по одному из последних его стихотворений полностью сознавая, что о публикации под коммунис гами не может быть и речи. $K$ концу $70-x$ годов он надеялся, что на западе найдется такая возможность, но только несколько стихотворений было опубликовано в антолог'иях.

Ян Сатуновский был хорошо известеи в кругах „Второй культуры“. K его друзьям принадлежали Геннадий АйІ'и, который согласился написать послесловие, и Георгий Оболдуев. Вместе с Гсирихом Сапгиром, Всевололом Некрасовым, Эдуардом Лимоновым, Игорем Холиным и Владиславом Лёном он составил кратко просуществовавную группу „Конкрст“, упомянутую в Парижской антологии Михаила Шемякина .Аполлонь-77".

Ян (настоящее имя Яков) Сатуновский родился 23-го (10-го) февраля 1913 года в Екатеринбурге, учился в техникуме в Москве, вошел гам в контахт с конструктивистами и начал писать стихи. В 1931 r. он вернулся в родной город, учился в университете на химическом факультете и работал журналистом. Всю войну он служил офиісером, сначала на фронте, а после ранения, корреспондентом газеты „Патриот Родины“. После войны ои работал двадцать лет химиком в городе Электросталь под Москвой, а наряду с этим стал иисателем. С одной стороны он иисал свон, обнаруживаюиие огромную внутреннюю независимость, весьма краткие стихотворения, с лругой он написал детские книги (14 до своей смерти), которые он и мог опубликовать.

Прозаические стихотворения Сатуновского - отблеск духовных страданий русского интеллигента под советской властью. Это точно датированные и даже нумерованные записи внутрениих переживаний, связанных с внешними событиями. „С одной стороны, кажется, перед нами фрагменты случайных мыслей, бытовые фотоснимки, удачно (кем-то, когда-то) произнесенные фразы, - словом, повседневность в современном се понимании. Но, с другой стороны, мы постоянно видим, как растет, строится стих, видим графический или речевой ход, то есть замечаем условнос'ь текста и его многочисленные смысловые возможности. И объединяет эти две разности язык, такой заразительный. такой обманчиво простой и узнаваемый." (Б. Колымагин, ж. „Октябрь“ 1993.5, стр. 187.) Сатуновский жил своими стихами, только они дали ему возможность существования под искалечившей его жизнь диктатурой. Он умер 12-го августа $1982 \mathrm{r}$. в Москве.

Первые его стихотворения появились в 1977 r. в Париже и в Белграде в антологиях. В России стали печатать его только во время перестройки С 1987 г. Одновременно его брат Петр Сатуновский и я стали подготавливать издания сборников, не зная друг о друге. Московская книга „Хочу ли я посмертной славы“ вышла в $1992 \mathrm{r}$. Так как в основс моего издания лежит 
составленное самим автором в $1974 \%$.Избранное в трех томах“, выгущеннос им самиздатом в семи экземглярах, который мне по оказии переправил в Германию Геннадий Айли, я хотел сохранить его здесь полностью. Кроме того у меня в руках были подобный лобавочный авторский томнк от конца 70-х Іодов, собранные последние стихи начала 80-х, перепечатанные также самым Сатуновским и перешисанная автором лля меня от руки в 1979 г. ге'радь с краткой автобиографией и выборкой стихов. Пользуясь возникшсй с конца 80-х годов для меня возможностью нормального контакта с Россией я попросил брата иредоставить мне все, найденные им дополнитсльно к этому материалу стихотворения. Все это, включая Московскую книгу вошило в это изданис.

С целью экономии здесь, В отличие ог мациногисных оригиналов, Каждос стихотворение не напечатано на отдельном листе. В моей рукописной тетради антор, в огличие от перепечатанных им изданий. не писал типичными для него короткими (рублеными) строками, придаюцими им особый ритм, но подряд, только указывая абзацы и пробелы для выделения смысловых единиц. Все стихотворения, которые он не включил в три самиздатских книги 1974 г., напечатаны здесь по нумерации самого Сатуновского, т.е. хронологически. Стихотворения без номера включены 10 датам. Во избежание переносов отделыных стихогворений пришлось переместить несколько текстов, на что указано стрелкой внизу. (О других текстологических особенностях см. стр. 324.)

В приложении для научного пользования приводятся

1. Библиография публикаций в журналах и антологиях с указанием содержания

2. Реестр умпомянутых в стихах имен, прежде всего поэтов и писателей.

3. Реестр первых строк по алфавиту с указанием: а) перемещенных стихотворений, 6) стихотворений, включенных в Московское издание 1992 г. „Хочу ли я посмертной славы..." (Х.n.c.) и в) стихотворений, выбранных автором для рукописной тетради 1979 года (Ру).

Я выражаю благодарнос'ть Геннадию Айг'и и Петру Абрамовичу Сатуновскому за их помощь при возникновении книги, Обществу друзей Кёльнского университета за финансовую поддержку публикации, сотрудницам Института славистики Кёльнского университета Марианне Вибе и Беате Мейер и другим за перепечатание текстов и составление индексов, Марии Зоркой, Ирине Терегуловой и Наде Симон за чтение корректур.

Пусть эта книга послужит распространению знаний об этом удивитель ном и весьма важном для развития некоторых русских лириков поэте, служит его вкІючению в русскую литературу и подготовит сегодня пока еще не возможное издание большим тиражом в России.

Мух под Кёльном, весна 1994 г.

Вольфганг Казак 


\section{КРАТКАЯ АВТОБИОГРАФИЯ}

Родился накануне Первой Мировой войны - в 1913-ом. Мальчишкой пережил Гражданскую - махновџы, пикровцы, петлюровцы; наконещ, пришли наши - Красные.

Учился в семилетке, в техникуме, работал, потом поступил в Днепропетровский Госупиверси'гет. на химический факультет. Окончил, можно сказать, накануне Второй Мировой - в 1938-ом.

Войну Отечественную начал командиром взвода. А в 1942-ом, после ранения (у села Большие веснины) и лечения в Тульском и Саратовском госпиталях, был направлен в редакцию армейской газеты „Патриот Родины“. Балочки северней Сталинграда, Курско-Белгородская дуга, Украина, Польша, Дрезден, Прага - вот они, „этапы большого пути“ родной 5-ой Гв. Армии.

Победа. Дом разбомбило, пришлось переехать в подмосковную Электросталь, где предложили жить и работать. Дальше уже ничего не было „жил, работал, стал староват“ (Маяковский). „И жизнь прошла, успела промелькнуть, как ночь под стук обшарпанной пролётки" (Пастернак).

Много лет как автор на пенсии по старости. Вот, пока, и вся биография. Кроме того, что есть в стихах, писать почти что нечего.

1979

Ян Сатуновский 
00056818

40 rem innxyogrumi

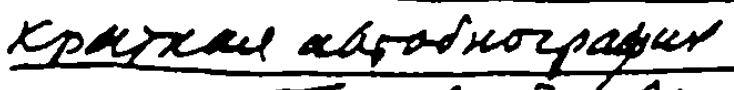

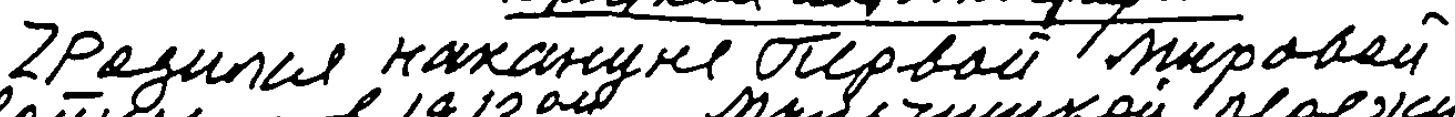

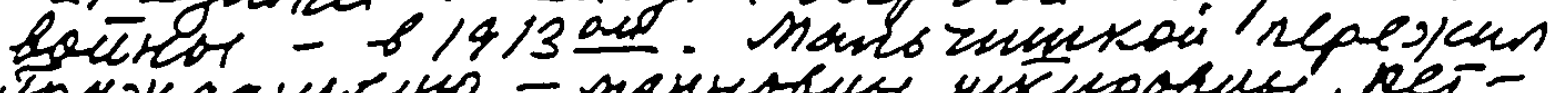

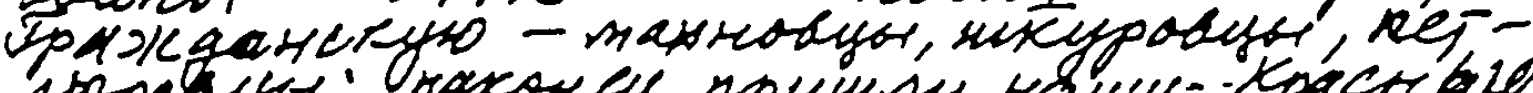

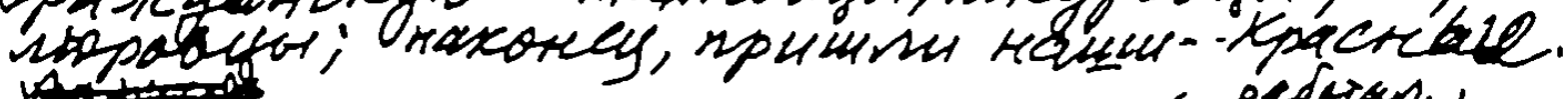
Dz pénan,

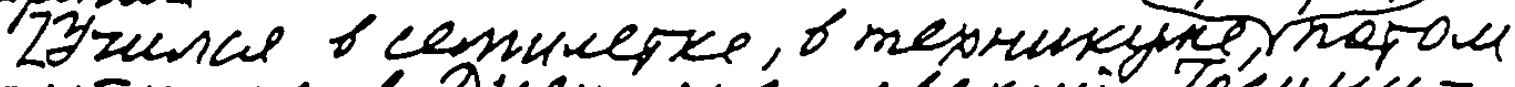
noceynun o Drenpone pobeni Jocytusepoure, tha xumureckui paryider: Okon.

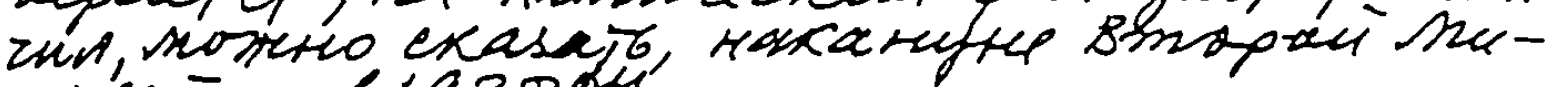
pobse- - 61938.4.

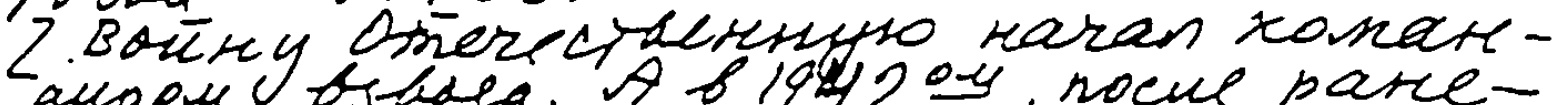
gupou bs hofa. A 81942 o-y, nocul pare-

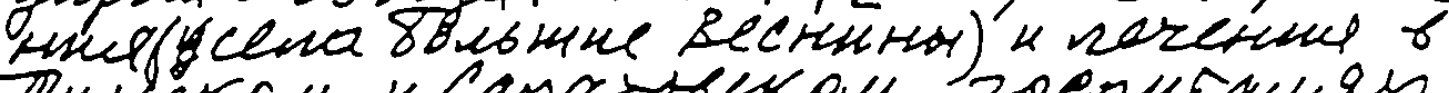

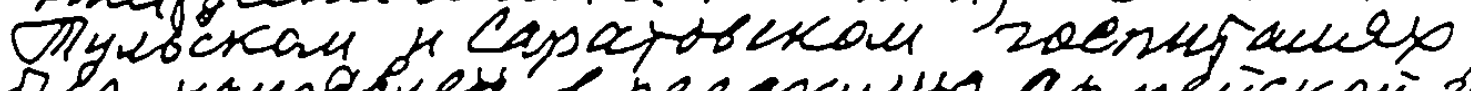
obs ransebren "sequxutto apmecickoi ra-

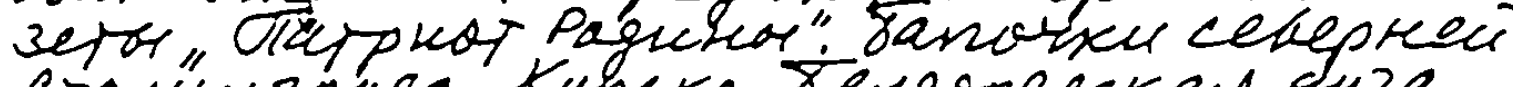

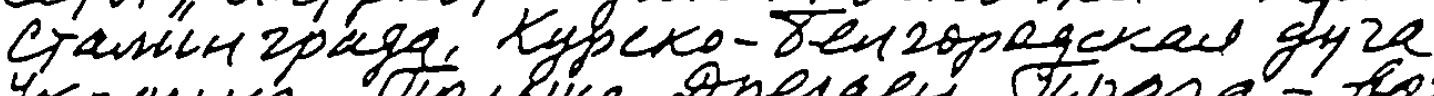

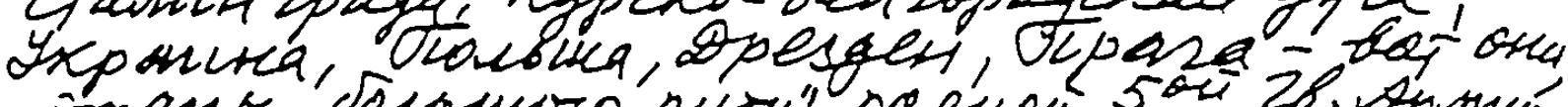

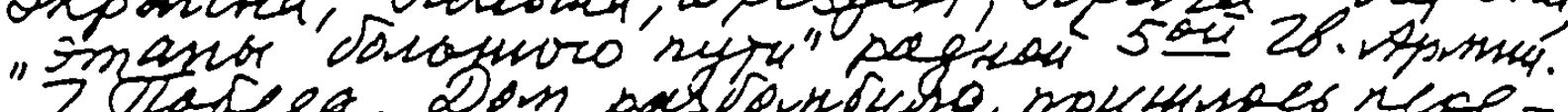
Sotaseg. Dom pas burbuso, mpusures nepe-

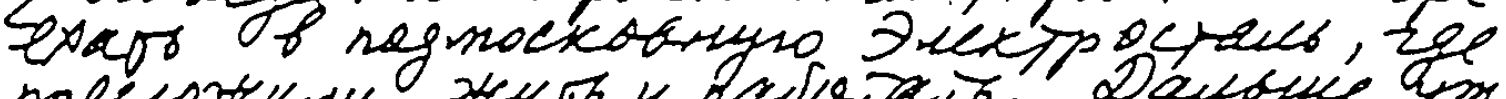

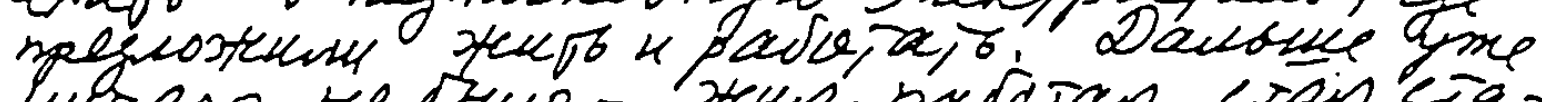
hureso re brwo - "Hun, patajan, cjain cja-

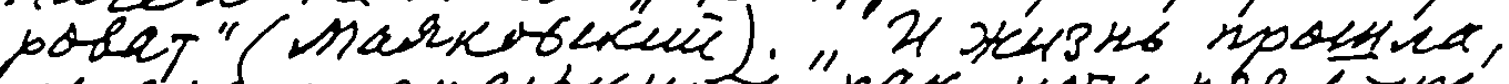
yenend mpompstery

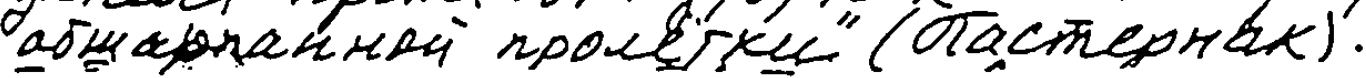

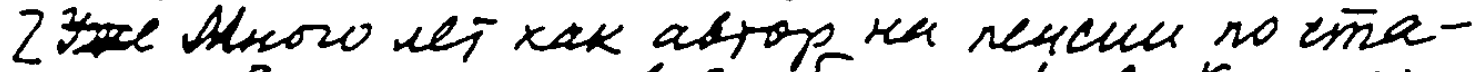

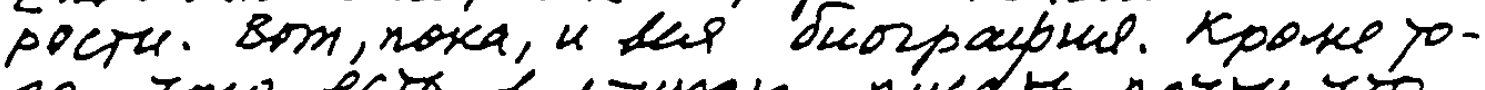

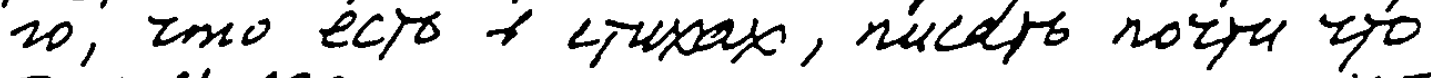
* rerezo.

1979

Из рукописи 1979 г.

Jan Satunovskij - 9783954795222

ia free access 


\section{Избранное в трех томах}

Тимур 1974 


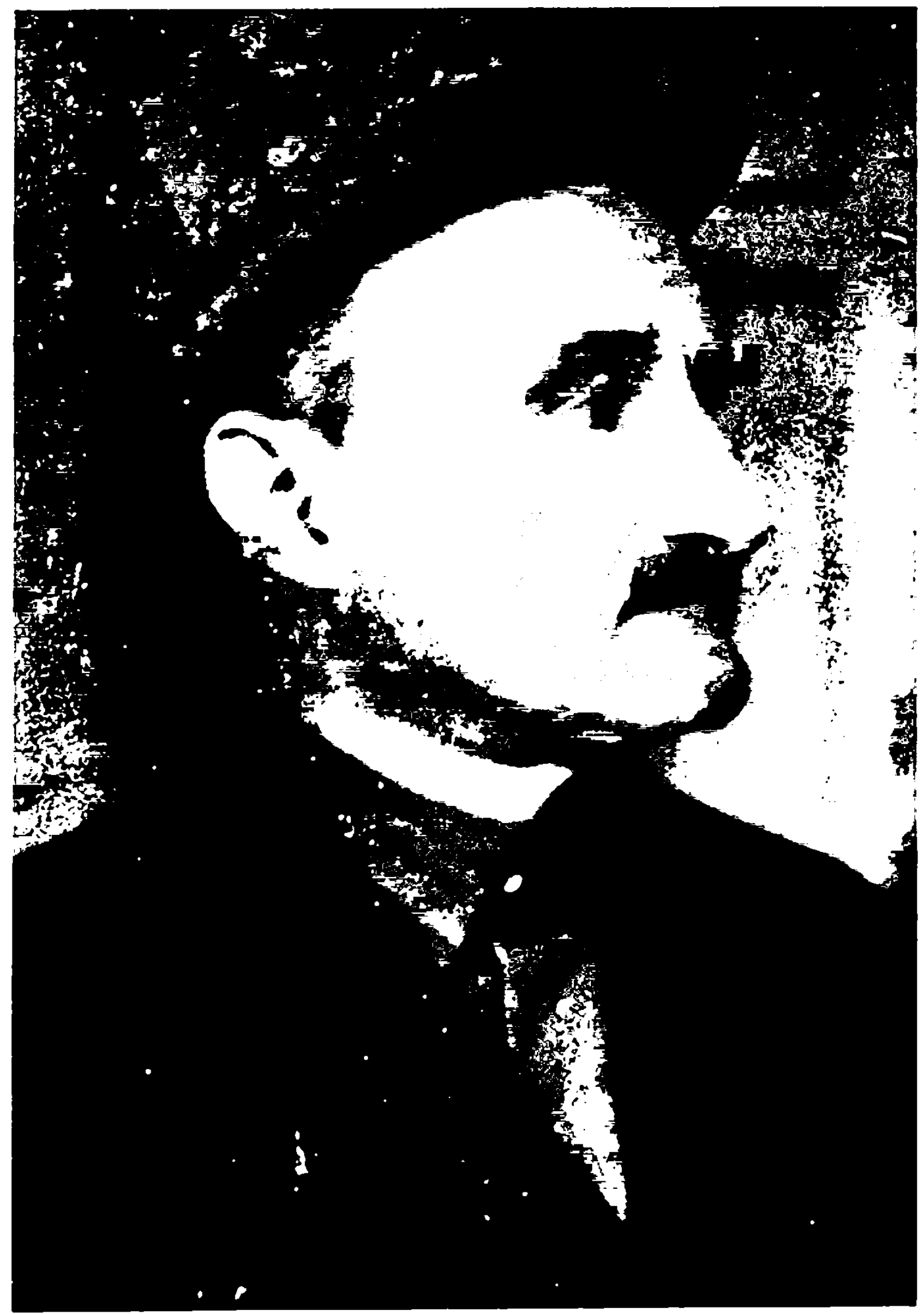




\section{ИЗБРАННОЕ 1974 г., ПЕРВЫЙ ТОМ}

187

Ох и славно до чего, до чего прежизнерадостно рано утром в минус двадцать градусов на работу бежать бегом.

А снежок под ногами похрустывает (вот как нравится мне этот звук!) и вокруг - всё такое русское, что - захватывает дух.

27 ноября 1959

188

Людка-Милка, мелкая завивка, трепаная юбка, Милка-Людка, даром, что ли, люди говорят, что у Милки-Людки золотые руки?

Я смотрю на них, на эти пятерни, грубые, в рубцах и ссадинах; вот какие - сильные и слабые, судьбе покорные - они.

8 апреля 1960

356

Весна, весна! - лопоча, заплетаясь, струясь, виясь, от Христа отрекаясь, вериги свергая, ломая кости, на дубе, на дыбе, на старом погосте, в Калуге, в овраге, в Клину и на Пресне, свергая вериги - воскресни! воскресни! из тлена, из плена, исподольда, в снегу по колено уходит вода из плена из тлена... 
Захлопнулась калитка:

в укрытие уинла

согливая улитка,

еврейская душа.

А Хаиму до гроба

не скрыться

от зверей.

or грома,

ol llor рома,

or окон,

от лверей.

28 декабря 1967

Шесть дней вкалывай.

седьмой -

выходной.

„Румяная, заспанная жена в халате и пшлепанцах“ • чистит картошку.

На кухне газ.

По радио передают „С лобрым утром“.

На мягком диване лениво щуригся кошка.

И

грезвая мысль:

а не сбегать ли

за поллитром?

Шесть дней вкалывай,

седьмой -

выходной.

13 ноября 1963

- Цитата из рассказа Казакевича 
Бей своих, чтоб чужие боялись! этот лозунг

мы слыним давно.

Били нас,

в тюрьмы сажали,

рыбами

спускали на дно

- Бей! в бога мать и в зубы.

с ходу,

во весь развворот.

- Бей!

Веселее будет русский народ.

9 инля 1961

93

Берегись поезда.

берегись трамвая,

берегись автомобиля.

берсгись пня,

берегись рва.

берегись завтраинсго дня -

всё равно не убережешься - нож в спину.

клык,

а то и безо всякого: „космополит!“

(в скобках - Месро́вич) -

„Безродный!“

„Антинародный!"

„Растлить его!"

Ну, хватит, не канючь:

как ра3

ликвидируют,

Kak KJacc. 
Две

дворничихи

посреди Второй Тверской-Ямской

стояли с вёдрами,

и, с подлинно материнской тегилотой

в голосе,

переговаривались.

Я проходил мимо.

Я шёл,

больной,

издёрганный,

в шляпе и воротнике.

Был март, ноль градусов.

По улицам к Москве-реке

стремилась

мутная и отвратительнейшая жижа.

Две женщины переговаривались.

Не слова -

слов я не сознавал -

a-

са́мые голоса,

са́mas

простоголосость их душевной щедрой сути ошеломила меня.

Я встал около них, смутных и ласковых.

Я выздоровел в этот миг.

И потом - целый день думал о русских людях.

1949

596

Это уже не кошки-мышки,

это уже скидавай да нишкнй,

все ухваты скандавались.

кочерга пошла плясать,

и шелепая задвига

навалилась на чердак.

$\rightarrow \quad 2$ сентября 1968 
И, как с похмелья,

cmaxy:

cтих

это смех со страху, -

o, рассмейтесь смехачи,

о, рассыпьтесь, страхачи смерти,

слухачи!

12 декабря 1967

622

Степной нечёсанный растрёпа...

Б. Пастернах

Растрёпанный неряха,

капустный бригадир,

он в гости к Пастернаку,

случалось, заходил;

зелёным самосадом

осыпанный до плеч,

с ауткой-прибауткой,

с затылком в пятерне,

бездельник, плут, трудяга,

явился нынче мне

от мыслимых ошибок

всерьез предостеречь.

11 января 1969

692

Поговорим с тобой

хак магнитофон с магнитофоном,

лихая душа,

Нехрасов Николаевкч Всеволод,

русский японец.

$\rightarrow \quad 17$ сентября и 7 ноября 1970 
Письма до востребования, письма невостребованные,

девочки беседуют

про моду иностранную,

а снежинки падают -

ценные,

бесценные,

тканые,

нетканые.

12 октября 1968

595

Посещение А.Е.Кручёных

Мы с тобой на кухне посндим...

Oc. $M$.

Беленький, серенькмй Дырбулщил:

- К Троцкому я не ходил,

к Сталину не ходил,

другие кадили...

Слабость, и задышка,

и рука-ледышка.

Товарищ гражданин,

присядем, посидим.

А потом из ручки Глоцера разборчиво:

Поэту Я.А.Сатуновскому

AKp-

16/XП

1967 r.

Mockвa

I сентября 1968 
Какая тишина, какая благодать!

Не надо тратить сил на мимику, все ясно,

и кажется, что душу оставляет, бередя, свобода выбраться из необходимости.

19 asrycta 1968

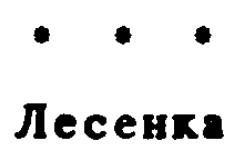

Розовый

Синий

платочек

чолку

пушу на

схромные

чело

блядские гла- азкн

чего же вам надо ещё?

Не зови

меня

Людмилой

Людой милой

не

30ви

назови меня

самой любимой

и в "Aparвy"

(повторить)

пригласи 
- Засыпьте как было, сказала мисс Хรббершем.

И вот прошло столько-то лет, и за двумя рядами стёкол,

В освещённых окнах он видел

мужчину с подтяжками, женцина за телевизором вязала;

а за стенами этой тихой, освещённой лампой команты ... о́вая

... вира

... не́вери ревела,

не приближаясь $\mathrm{K}$ полночи,

a волоча её за собой, не затем, чтобы швырнуть полночь

в крушение, но чтобы

изрыгнуть на них

останки крушения полночи

одним

хладнокровным

зақрывающим небо

зевком...

И ОН вСпомнил:

они все трое думали об этом, но никто ничего не сказал.

Tax

с букетом олеандров

и с коробкой постного сахара

на углу Провальной и Кирпичного...

... С ганстерами - о нравственности...

... с извергами - о Гинзбурге... 


\section{Шаламовское}

Гражданин начальник, тут какая-то ошибка, я не тот, которого надо убивать, я сам умею убивать.

\section{Бахилы,} Kopo6a, грабарки, фанерные бирки, чем ты болен, такой здоровый лоб? Обзовись!

8 февраля 1968

451

Поэзия - это то, что я себе позволяю.

Что я позволяю себе, и чего

не доз-во-ляю.

Всё в норме, всё, как говорится, в целости.

Откуда же этот комплекс неполноценности?

फнталн: Вазари.

Скулили: Челлини.

И- поделили:

Федыке - Татьяну.

Светлану - Степану.

А мне, малолетку -

Лeткy.

Не верьте!

Не верьте ни до и ни после смерти!

Поэзия - это то, что я себе позволяю.

Что я позволяю себе, и чего

не доз-во-ляю.

20 mоля 1966 
Осторожно, не оступись.

Осторожно, не споткнись.

Осторожно.

Tеперь направо.

Tеперь прямо.

Tеперь налево.

A, тебе пахнет!

А ты думал - за руль падло и чтоб не пахло.

Ну, ладно,

ложись.

Раздевается. Желток кожи.

Раздевается, чулки тоже.

Раздевается.

12 ноября 1964

307

Снег идёт.

Ложится,

мягок н легок

на задок,

на передок,

на шубку в обтяжккy,

на Машу-стиляжку,

Машу-дурочку.

Снег идёт.

A Maша-дурочка поёт:

„милый мой

ласков и жесток.

Больно хлещет

шёлховый шнурок“.

Снег идёт.

20 февраля 1964 
Позвонил соседу

и имел с ним беседу

при средних намолотах,

при высоком агрофоне,

10 а то и 15 ,

просо под вопросом,

оставайтесь с Гондурасом!

23 ноября 1968

685

Мужественно: утром пить водку натощак

(предпочитаю кофе).

Мухественно: состоять, по меньшей мере, референтом замминистра.

Вот так. Тик и так.

А я вхожу с авоськой, соль, мыло, лук.

На, пырни меня своими всевидящими, всененавидящими.

10 июля 1970

264

Рабин: бараки, сараи, казармы.

Два цвета временн:

серый

и желто-фонарный.

Воздух

железным занавесом

бьёт по глазам; по мозгам.

Спутница жизни - селёдка.

Зараза - примус.

Рабин: растивочно и на вынос.

Рабин: Лондон - Москва.

10 мюля 1963 
Был я на похоронах Мариенгофа.

Вот и окончен

„Роман без вранья“.

Первая рифма: „эпоха“.

Вторая рифма: „а я?“.

27 ноября 1963

292

Перечитываю снова и снова.

От шмона до шмона.

Тут тебе и маслице, и фуяслице, и Гопчик, и Кильгас.

Эx, глаз - ватерпас:

попки на вышках!

Значит, выпустили, не доканали

сочинителя-доходягу -

Солженицына!

3 декабря 1963

79

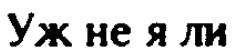

Василий Буслаевич,

что с живыми мыслями поигрываю,

что для красного - с кровцой - словца

не жалею мать с отцом?

Погляжу я на себя

в парикмахерской:

ой, да ты не гой еси,

не добрый молодец;

лысина на голове,

плюгавый род;

жёсткую сединку

брнтва не берет. 
Kax

я устал!

Устало сердие

кровью

умывать глаза.

Глаза -

глазеть

на путаницу этих улиц,

лиц

и сцен.

Устала

кровь

толкаться с шумом

В тесных жилах

вверх и вниз,

и вот -

уснула кровь.

1944 (в Германии)

57

О хак ты сдерживаешься, чтобы не закричать, не взвыть,

не выдать себя

ничем

посредн топота

спешащих жить, -

поскальзывающихся,

встающих,

оскаливающихся,

жующих,

сталкнвающихся

ло6 в ло6 -

толп, толп!

1946 
Ках будто всеми десятью пальцами

по стеклу,

Tak

душераздирающей своей фальшью

ты, музыка Москвы,

ты, мучающая слух музыка Москвы!

0 , скупка вещей от населения!

0 , литер $\mathrm{B}$ !

0 , отделение для обслуживания

беременных и кормящих матерей!

1946

24

Мне снилось: я еду на грузовике.

Ни

вспышки зелёных ракет,

Hห

зги.

И вдруг начинают стрелять.

И самая первая пуля,

визжа и сверля,

разнимает мне грудь

и застревает внутри.

И я просыпаюсь.

Я жив.

327

Кто во что, а я поэт.

Кто на что, а я на С.

Стою по ранжиру

между Слущким и Сапгиром.

Захат - зняющ

и клокат.

Не на закат смотрю -

B закат.

$\rightarrow \quad$ S oxтs6ps 1964 
Я не хочу всё знать.

Я ничего не хочу знать, не хочу знать, знать, знать, и всё ни для чего.

Лучше быть как дуб.

Лучше

cтать

дубом.

Дубу корни для того, чтобы врыться в землю.

Чтобы стать, и стоять, стоять.

И не думать ничего.

1946

64

Верю народу, во всём верю народу.

Что народ говорит, то-есть.

Брось, говорит народ, брось,

не думай

о доле народа,

о боли народа,

пей, говорит,

пей до дна,

пей, тоска пройдет.

Я бы и рад

"Топить в вине тоску-злодейку“,

мутный стакан

не расплескав, нести х губе, да не идет мне, видно,

BITPOK

московское зелье,

страшно похмелье,

тошно,

слабый я человек. 
Фальшь - гугуманизм,

и с ложью

схожи

слезы.

Все пелёнки,

все одежды

с кожей слезли.

Голый как язык,

я, может быть, один

над бездной

Bойㅂ

и бедствий, -

но, клянусь,

дышу надеждой,

что, преодолевши

блакь

и скудость мыслей,

блажь гугуманизма, робость,

уз30стb, -

y -

заговорю,

зайдусь, за весь свой

род-

измученный,

изувеченный,

3a-

чёрт с ним, -

за человеческий!

572

Поэзия гиблое дело,

дерьмо, и- какое мне дело?

В санбате, на прелой соломе

мы думали думу о доме.

Радисты морзят телеграммы,

а смерть отпускают на граммы.

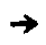

4 апреля 1968 
Судом История,

судьбами мира вершащей,

приговоренные

к высшей мере счастья, веря в Грядущее

или лицемеря,

отступы к Прошлому пристрелявши,

мы,

дети

атомного

коммунистического века,

всей протоплазмой,

всей плотью-в Настоящем;

не потому ли

и вознесены

сверх меры

судом Исторни?

664

Борис Пастернах

Любить - идти - не смолкнул

гром...

Пастернак

Слова, полуосвобожденные от смысла:

шоссе; сошествие Корчмы; как с маршем бресть с репьём на всём;

разлегшись, сгресть, клочьми,

и - дальше-больше -

начисто освобождённые от фальши.

1 апреля 1970

729

Память войны-ыыы:

под флагом луныыыы

проходные дворыыыы...

$\rightarrow \quad 7$ охтября 1971 
Ты говорншь:

он всё забыл,

он всё забыл,

он незлопамятный,

нет,

не злопамятный

а беспамятный,

не вспомнил,

значит, не любил,

ты говоришь,

xотя,

по правде говоря,

романсу 6 я не доверял.

16 января 1970

655

Романс

Ещё вращается Земля.

Ещё прощаются морозы.

А трулюлю как труляля.

И кукуруза как у розы.

Явись, душа моя, распнись!

Сноп

осыпается с ресниц.

20 декабря 1969

314

Заговаривал зубы девчонкам.

Твист танцевал.

В сухой траве

пещерной хаменной бабе бухтел о любви.

30 лет принудиловки брака, 33.

Нет. Ничего не хотел. Никого не любил.

20 aarycta 1964 
У тебя в груди передвигали шкаф.

Ты устал, не надо шевелиться, спи спокойно;

завтра утром, встав,

ты раздвннешь радугу в ресницах;

завтра утром в ставни дунет день

звёздами снежинок;

утром завтра

встань, умойся, шейный шарф надень

и на снег, на воздух, $\mathrm{x}$ соснам, за́ город,

завтра утром, встав на снег со сна...

Кровь из горла; оттепель; весна.

3

Отхаркнув, исследую мохро́ту.

Нет, хрови ещё нет,

Это ещё не чахотка. Это

не жизнь вываливается через рот.

Я видел гибнущего от чахотки.

Он был, как янчный белок.

На костяной скуле его

сухой и чёткий

торчал кровавый плевок.

558

\section{Платоновсхое}

Ках вспугнутая стая белых птиц,

как звук влекущегося ветра,

ках пробивающаяся сквозь прах трава,

ках несбывающаяся музыка

у расплетённого плетня,

В тесноте своей печали,

надев свой ватный

жёлто-тифозного цвета пндхах,

на рваной и рубленой шинели. 
Ты, вечно хныкающий о своём больном здоровье, ты, мнительный, ты, слабовольный, малокровный, остерегающийся - сырой воды, очередей, сигналов автомашин, случайных скандалов, уличных собак ты, как ты воевал, как?

Не знаю, ничего не знаю.

Ни зноя малинового, ни звона, ни сна и ни солнца, ничего;

а знаю - бьётся, бьётся сердце, бьётся не переставая, а с груди простреленной - льётся что-то, медленно натекает в сапоги.

728

В век сплошной электрификации всем Bcë до лампочки.

Так что даже левые поэты пишут правые стихи.

2 октября 1971

620

Подумаешь, тоже работа...

A. Aмматова

Пишу стихи без малейшей затраты сил.

Иwa4y,

партачу как сукин сын.

Подумаешь, тоже работа: валяй, чеши.

Ребята, вы слышите - он ещё пишет стихи.

9 января 1969 
Жлоб Муня ку́хает коло калитки.

Жлоб Муня збирит за профб́с.

Это не дикторская речь.

Не докторская.

Не инженерская.

Как вам это понравится - Жлоб Муня ?!

21 ноября 1971

739

\section{Романс}

Русская женщина только пригубит, только чуть-чуть отхлебнёт любит, не любит, тьфу, поцелует, $K$ сердцу и $\mathrm{K}$ чёрту пошлёт.

Ибо всякая русская женщина, даже из самых простых, это женщина Пушкина, Гоголя, Герцена, женщина Bcex Трех Толстых, женщина Пушкина, Гоголя, Герцена,

Всех всех Толстых

26 ноября 1971

Oтит, скарлатина, летит паутина, коклюшное небо, синьшное небо, клетухн в тифу, у деревьев желтуха, пришлн сентябрины на тощие глины.

$\rightarrow \quad 19$ сентября 1968 
Рецензия на поэмы Игоря Холина 1968 г.

Холин искал себя на Марсе, а нашел в Марьиной роще, когда хоронили Александра Давыдовича, отца Киры Сапгир.

Что значит - поэт нашел себя?

Когда-то Флобер сказал: Эмма - это я.

Поэту среднему достаточно, чтобы читатель узнавал: это Хфлин.

Большому поэту надо, чтобы читатель узнал: Холин это я.

Тогда стихи перестают быть предметом эстетической оценки, например, любования: „ах, как это здорово сделано“, или "каК это ново“, или „каК интересно“, а становятся религией после дних дней человечества.

8 января 1969

805

Oпять чего-то гомонят из-за границы какой-то Сахаров, какой-то Солженицын.

Пустые хлопоты, напрасные заботы, нам не до Сахарова, не до „Свободы“.

Ломаные мостовые, кривоулочки пустые, домики со ставнями наружу, вашей тишины я не нарушу.

9 сентября 1973, Днепропетровск

806

Как сказать: „су́дно“, или "судно́" понять нетруддно, не по́нять трудно́.

По набережной прохаживается русалка без хвоста.

До чего же, на самом-то деле, Россия хороша!

24 сентября 1973, Ялта 
„Свободу" надо раскавычить.

Россию можно закавычить.

2 октября 1973, дома

600

Моё тихоюбилейное - шестисотое стихотворение, написанное через 30 лет после первого

( „У часового я спросил...").

91

Что ж нам делать

с нашей мачехой,

сущей

сумасшедшей,

выколачивающей

из падчерицы

душу человечью?

Или нет души у Золушки?

Что вам делать

с вашей совестью?

583

\section{Глаза}

Светлые,

но с темным ободко́м;

предпочтительно светло-серые;

с чем сравнить вас:

с добрым о́блачком?

С бодрым утром?

с воскресеньем?

Так светите, несравнимые, ни реальные,

ни мнимые.

8 июля 1968 
Мне нравится эта высоколобая холодног лазая дама.

Мне нравится задумчивый овал ее лица.

Ее потухшие волосы, как листья Левитана,

( хотя, разумеется, возраст по ним установить нельзя ).

Оказывается, живёт ещё в душе нелепое чувство.

Мне стыдно сознаться: мне хочется позвать её, остановить, упасть перед ней на коленку, и левой перчатки коснуться, и чтобы в ушах - соловьи, соловьи, соловьи, соловьи...

18

Кто вы?

Pепатринрованные вдовы.

Так едко я хотел съязвить о них,

Ho

не поворачивается язык.

Устав от гитлеровских зверств, убийств, бомбёжек и насилий, они приходят в офицерский сквер, чтоб их не воспитывали, а любили.

Caparos

165

Ax, какой гул и треск,

гул и треск,

хруст,

38OH!

Что творится в печи?

Звон и смех,

пыл и стон!

Кто там мчнтся -

Вскачь

сквозь метель прямиком?

Кто там плачет?

Не плачь!

Хорошо, горячо! 
От Ерундин до Мерехлюндия 6 хилометров.

А от Мерехлюндия до Ерундия 9 километров.

В Ерундия растут на вербе груши, а в Мерехлюндия плодоносят туи.

В Ерундии живут ерундивисты, а в Мерехлюндии - мерехлюндеи.

Я лично побывал в обеих странах, смотрел метро, пил пиво в ресторанах, и вот я вам спою на злобу дня куплет из оперы „Мерехлю-мерехля“. 8 нюня 1965

410

Спасибо папе Павлу: он снял с евреев грех за то, что мы распяли Спасителя-Христа. А я с одной грузинкой спал года два назад. При чем тут папа-Йося. который был резняк?

И все-таки, по правде я чувствую вину 3а тех жндов, вопивших „распни Его, распни!"; но и за папу-Йосю есть на мне вина, хотя бы групла крови у нас и не одна.

15 декабря 1965 
Да, Вы пишете очень прелестно:

в вихре вальса трехсложных стихов

рнфмы выглядят, как невесты,

независимо от смысла слов.

8 января 1972

744

Коррупция, корпорация, - не говори!..

Два бита ценной информацин.

Нет, целых три.

И эта песенка дурацкая:

„го-ри, го-ри, го-ри!"

9 января 1972

746

- Добрый вечер,

щедрый вечер, -

и, минуту погодя,

- Квашня, говорит, старика месит

( это, верно, про меня!)

13 января 1972

476

Жили были два дуа́ -

Ромуа и Моруа.

Моруа строфил эссе,

а Ромуа кафил гляссе.

Ну, а нам-то на труа

Моруа и Ромуа?

На труа нам Моруа

и Ромуа нам на труа?

31 января 1967 


\section{Зацепился}

за декорацию

Гамлет,

мямлит:

- Так-то, друг Горацио... -

А нельзя ли

решить

большннством голосов

философ-ский вопрос -

быть, или не быть?

26 декабря 1968

76

Дёрнуло - вперёд, назад,

раз, другой,

и покатились

будка на колёсах,

луха,

огород,

глина,

глина,

cynecok,

суглинок,

и уже -

один

столбы

стучат в глаза.

$1948 ?$

740

Тихий голос, слышный всякому, покачался на цветке.

Он теперь несется в вакууме

К несозданной звезде,

тихий голос, слышный всякому.

6 января 1972 
Молодые дамы, Лоры и Ланы!

Потерялся черновик, мне теперь не сочинить даже двух-трёх четырёх строк.

6 января [1972]

742

Всё, что было - прошло;

Всё: любилось - не любилось -

всё - забылось;

затупилось и зубило;

помело

следы замело.

7 января 1972

674

... н каждый думал, и молчал

О чем-то...

М. Исаховский

По радио - военачальники.

A '

с молчанием

рифмую 9 ма́я, -

o TOM,

о чем не молчали.

9 мая 1970, Ялta 
Займусь-ка я мирмекологией.

Засуну палец в муравейник.

Исследую

влияние

физического скопления особей

на свойства скопившихся.

16 февраля 1968

540

Тах, ничего определённого;

Нечто неопределённое;

нечто туманное,

млечно-серое

на сумеречном фоне.

А сердце бьётся, сердие бьётся

все ревностей,

все обречённей;

Как будто вырвется сейчас изнутри

во все четыре измерекия.

3 декабря 1967

375

Миру мир

миру мир

миру мир

мир умер

$\rightarrow$ Hrons 1965 
Я как дурак в деревне.

В ономнясь, анадысь, намедни.

Я, как слепой, копаюсь в огороде,

ни В огурцах не разбираясь, ни в моркови.

Старорежимный, семижильный кочет, о чем надсаживается он, чего он хочет?

Я не пойму. И борозды и грядки

мне просто-таки как в линеечку тетрадки.

\section{1}

В молодости

я

слышал Лемешева-соловья.

Aх, как бьется сердие

зло и горько!

Тройка, тройка,

гай да птица тройка,

белый полог,

розовая зорька,

молодость

моя

и не моя...

И чего мне

не строчить романсы,

что я,

лучше

или хуже тех,

за которых

лично рассчитался

Маяковский,

чудо-человек.

30 декабря 1958 
В отвыкшей бить жидов стране

पTO

душу перевернуло мне?

Зарыты старые рубаки

из чёрной сотни - чёрный сон.

Еврей в ухраинской рубахе -

твой друг - медалью награждён,

да ты и сам женат на русской, -

чего $\approx$ тебе ещё, еврей?

0 чем вздыхаешь ты, еврей,

поскрипывая костью узкой?

Ках мне сказать стране моей, как объяснить ей, маме, маме,

какиоми

русскими словами -

о жути жить?

о боли быть в Берлине жалким юдэ - жид?

Днепропетровск 1939

35

Как я им должен быть отвратителен! С собачьими глазами.

Медли-ительно-предупредительно прохаживающийся по казарме.

Внимательнейший: - простите, я вас - не?..

- A, к матери, слоняются тут ках во сне.

Но я не сонный - я заторможённый.

Зато как на меня смотрят мальчики со скрипками, библейские мальчики со скритками, во все свои лампочки - лампеня -

во все свои - светят - чёрные и карие, во все свон - чёрт знает какие, такие, какие у меня. 
Читаю назидания Абая.

В дверь, то и дело, как из бани,

с мороза, отворачивая воротники,

Bступают

женщины,

подростки,

мужики.

Я наблюдаю

повадки их,

ужимки,

ухмылки, от которых дрожат поджилки.

- И вот страна, в которой я живу, - писал Абай.

- И вот народ, который я люблю.

33

Я их не не ненавидел,

пока я их не увндел.

Они все были как душевно-больные, „Фриц, а, Фриц, хочешь пить?" еле двигались и быстро что-то говорили, „скахи гитлер - капут“.

Не я, не я, а косомордый писарь „Ну, Фриц, сказал гитлер - капут?" постоял за углом и вынес полную флягу „на, враг, пей русский суп“.

Не я, не я, а ваши вшивые Фрицы „Жид, а, жид, хочешь пить?“обливаясь, долго глотали жёлтую влагу, „жнд, а, жнд, перекрестись“.

$\rightarrow$ (это - в войну, когда освобождали
Венгрню, 44-ый, долхно быть) 
Пусть стал я как мощи - ясен дух у меня.

Срослись мон кости, о мясе нечего и вспоминать.

И не вспомнится, и не приснится

черепичная заграница,

заграничная чечевица.

Все дороги ведут в Москву.

Все народы по ним пойдут.

Изнасилованные фрейлен Ильзе, ауфвидэрзэен в социализме.

21

Сейчас, не очень далеко от нас идёт такое дикое кровопролитие, что мы не смотрим друг другу в глаза.

У всех - геморрондальный цвет лица.

Глотают соду интенданты.

Трезвеют лейтенанты.

И все молчат.

Bcë

утро

било, а сейчас -

BCë

смолкло.

Молча,

разиня рот,

облившись потом,

молча

пошла пошла пошла пехота

пошла ролимая ...

$\rightarrow \quad 1944$ 
Как же это так случилось, как, скажи, что опять, как чирь, вскочило, и не сходит с языка народа слово - жид?

И за что мокх двояшек - суржичек моих называют сарочками и колотят за десятерых?

И зачем из института было выгонять Минкину и Гозенпуда, Лившида, Ванштейна, Розенгарта, Розенцвейга, называйте любую еврейскую фамилию, если не по пункту 5 ?

И стыдливо не потупит ни один из вас ваших серых, ваших синих, ваших светлых - слишком светлых глаз!

17

Чужие слюни, слёзы, сопли на наволоке не просохли.

Я сплю и слышу: „строить людей на уборку лошадей!“

Они все рвутся на фронт.

а я вижу - из всех рвёт.

Kогда кого-то

откомандировали на фронт они блевали.

Мы будем гнить.

а эти гниды будут жить.

Пустите меня, я пошутил, у меня уже больше нет сил, мне не надо ничего на свете, дайте час доспать до смерти. 
Но разве мыслили мы, чтобы Днепр о п т р в ск стал пустым местом?

Ни знакомых, ни родственников, никого, даже выпить не с кем, не примазываться же к иным, безусым, -

я, должно быть, кажусь им беженцем, переселенцем, выходцем с того света.

Здесь я прожил 27 лет.

Отсюда пошёл на немца.

9

Чёрт побери, насколько это лучше, чем погибать в каком-нибудь... Луцке!.. сидеть дома, радио включив, и думать: дули, дули вам - я жив; и зажигать свет в ватерклозете, и перечитывать сообщения в газете, и, задохнувшись счастьем, пронзнесть:

- Чтоб я так жил!

Ведь там люди есть!

368

Моё - не моё - небо.

Мои - не мон - звёзды.

Теперь они - реабилитированы бессмертные - посмертно.

Прими меня, блудного сына; целую, припав, твон ляжки, В рубашке из майской кашки, мать-мачеха, Украина!

$\rightarrow \quad 30$ мag 1965, в noeзде 
- Девушки

с золотыми глазами,

где вы

золото для глаз свонх

6рали?

- В церкви:

разбазарили

образа,

разобрали ризы

на глаза.

- Девушки - чернооки,

а вы где?

- В синагоге.

16 декабрл 1960

42

Уже час, по нашему два.

Кончай чаевать.

Они уже тоже, кажется, догадались, встают, составляют стулья, гутэннахт, старуха делает книксен: биттэ, ах, ауфвидерзэн;

слава Богу, выдворилась;

что же дальше?

Из кухнк, стеклянную дверь открыв, с эмалированной миской вкатывается Мари.

Ясно.

Я снимаю пояс,

и, ки́рзовые сапоги разув, моюсь в эмалированном тазу.

Молча моюсь.

Моюсь до тех пор, пока, нырнув в кровать и взбнвая лохмы на подушке,

Мари

начинает

тихо хохотать.

Угу, такая толстушка-хохотушка!

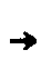


Им говорят, а они молчат.

- Ребята, - говорят.

-Герон, - говорят.

- Решительный час настал.

- Вперёд, - говорят, - назад.

Им говорят.

Ну, что ж ты молчишь?

Не молчи, мычи.

Вой, Иван.

Сейчас тебя на убой.

Я тоже, я с тобой.

Я рядом, кричу - вставай, кричу - давай,

кричу...

Кому-то надо кричать.

10

О чём мы думали?

„О6 жизни; и ещё 06 кой 06 чём:

о пушке на лесной опушке;

о воске детских щёк;

об оспе, н о кори;

о судорожном отпоре

их мам,

которых я смогу

насиловать, обутый в сапоги".

1940 
Нет, не то, чтоб из какой-нибудь надобности В этом деле надобности нет захотелось почитать поэта Нарбута, был ведь и такой поэт, были ведь на свете всякие, вот, откуда ни возьмись - Зор-ген-фрей! литературная шатия, братья писатели, кто вас помнит, кто вас знает теперь?

Это немыслимо, бессмысленно.

Это не вымысел, не мистика, не в прошлом веке, и не в будущем, это не "там уже", а тут ещё -

в Лобне,

в Купавне, вне мер и весов, за гранью, за мороком антимиров голос должно быть, Блока: любовь?

$$
4 \text { января } 1965
$$

\section{3}

Слова-то какие: кортеж, эскорт, такое не сразу и подберёшь.
А Никита Сергеевич курахится, а Микитка кочевряжится, дескать, знай наших, а ну, держись, расшибу весь мир, noжry Парих! 
Она была почти что шёлковая,

Когда я сбоху подошел $\mathrm{x}$ ней.

но беспощадно

и самоуверенно,

без тени сострадания $\mathrm{x}$ слабым,

она

всего меня

измерила

СвонМ

мгновенно-оценнвающим взглядом.

6 октября 1959

409

Мы были здесь осенью,

когда всё пламенело,

и всё знаменело.

Но для зимнего леса

нухны только ватман и тушь, только ватман и тушь...

27 декабря 1965

\section{Рецензия на стихи Эммы Мошховсхой}

У Эммы Эфраимовны весёлые заплақанные глаза. Большие мальчишпи не захотели играть с выряхенной соплнвой еврейской девчонхой, и теперь она пишет не об этом стихи.

Лучшие из них, думается, с професснональным интересом прочитал бы похоиный Зигмунд Фрейд (чего не схахешь о стихах других, благополучных, авторов).

Странность детского восприятия (термин Цветаевой) для всех нас - хнига за семью печатями. Эмма Мошковская, мо-жкет быть! - приоткроет перед нами эту книгу. 
Просматриваю девушек на свет; на свет, на свет, но если света нет; но если света нет, а есть - темно; а естество меняет существо; и я зову - откликнись, отзовись; я не садист, но и не мазохист; труба зовёт кого-то, но того, чьё существо меняет естество.

20 нюля 1966

652

Копейкин - калитан.

Лебядкин - капитан.

Товарищ Капитал из негрова Чикаго, кончается декабрь, последняя брнгада, последняя декада.

23 декабря 1969

589

Полюби меня, русская баба, раскабали меня, баба, красным, синим, из-за угла

полосни меня по глазам,

а то, что я ничер'та не помню, то, что я не могу двух слов связать, это не проформа, не стилизация, это - бессознательная сублимация.

Юные поэтессы, остепените гвалт, вы стремитесь ко мне, а я стремлюсь к вам. 
Бабка подымается бодрая, с давлением, с рвеннем

берётся за домашние дела, а намедни

важно поддала.

Вот и дед закашлялся с добрым утром.

Закури-ка, старче,

сигарету с фильтром.

5 декабря 1968

569

O Брехте,

о Мультатули,

о триппере, об архитектуре,

о кризисе

Квантовой физики,

O TOM,

что глуха́ порода

долдонят

враги народа -

жиды

и шизики.

31 мapta 1968

571

Обижайтесь не обижайтесь,

я уже привык, что люди лают на пруду

и радуются плёнке от канализацин,

что для пользы дела

свищут до обеда и трещат после обеда,

что касамо власти,

обожают чин, и ряд, и хрящик

не ина́че -

куры наши, а яйца не наши.

29 мapra 1968 
Посолонйда,

прожура́вьнна посолонида,

посолонида свев,

посолонида смнв.

Смерть,

све́рбни на пручь,

завербни в пучь,

посолони́, врад, в руд

посолониду, -

посолонидУ свев,

посолониду смив.

3 мая 1966, Ялта

5

У часового я стросил:

скажите, можно ходить по плотине?

- Идить! - ответил часовой

и сплюнул за перила.

Сняв шляпу, я прошёл

по плотине, овеянной славой,

с левого берега

на правый

и статью из Конституция прочёл.

Так вот он, Днепрострой!

Я вижу

символ овеществлённого труда,

а подо мной стоит вода

с одной стороны выше,

с другой стороны ниже.

Сентябрь 1938, 3апорохье 
Аэрария, дендрарии, Ривьера, Рица,

а у моря негде приземлиться.

Убивался недавно один земляк-человек:

- Моря в Сочи - навалом.

Фиг-навалом.

Солнца - навалом.

А у нас ничего нет.

7 охтября 1966

434

Надпись на спичеqной коробке

В Ясной Поляне могила Толстого.

В могиле его скелет.

Но Льва Николаевича Толстого

В Ясной Поляне нет.

Бросив усадьбу, двор, конюшню

писатель бежал от жены.

Остались

В неясной Ясной Поляне

опушки, шорохи, сны.

Но юных читателей

в библиотеках

встречают, помилуй Бог, и граф Толстой,

и А.П. Чехов,

и Хлебников,

и Мариенгоф.

7 апреля 1966

Вот хабы да не водка бы...

И всё ж таки -

наш кадр алкаш...

$\rightarrow \quad$ Июль 1972 
Пью

полной грудью

воспоминания о той, тайной и явной,

бывшей мне

другом и сестрой,

стройной,

ибо что на земле

стройней

строя.

возвысившего струны

души твоей, песня?

Каким мне именем назвать

самые тёмные,

самые светлые в любви глаза?

1951

197

И ни в сказке сказать

и ни в песне спеть.

Нелегко нам далась ты, казахская степь.

я

до дней своих донца

забыть не смогу,

как багровое солнце

остужали в снегу.

20 января 1961

198

Я верю только в труд.

Всё прочее - надстройка.

Я не смеюсь - нисколько.

Мир - дело наших рук.

Я верю, что весной,

освободясь от снега,

основа всех основ -

земля- ждёт сева.

26 января 1961 
И как она не щерится,

как ни ярится, -

сдаёт Зима Кощеевна,

сдаёт позиции.

Запарилась, осунулась;

уже под ударом

за улицей улица,

квартал за кварталом.

И хоть в снегу Черёмушки

и сам в снегу $я$,

гляжу на солнышко

и в ус не дую!

4 апреля 1962

756

Приснились

двоюродные дядьки - дядя Леопольд и дядя Мулле

(оба с маминой стороны); онн варнли мыло

из ничего, - дивное было время!..

В будущем клубе швейников ещё функционировала хоральная синагога

но мы не верили в Бога, -

мы, дети Карла Либкнехта и Розы Люксембург, верили в Красную кавалерию и мировую Революцию.

Дядю Мулле

я знал только по фотокарточке, но дядя Леопольд погиб ещё не скоро...

22 мapтa 1972

757

Нáu кадр, - anкаш...

5 апреля 1972 


\section{ИЗБРАННОЕ $1974 r .$, ВТОРОЙ ТОМ}

\section{3}

O, море, море,

мареме́йское море.

о, как ты гло́чешь,

божемя́.

караморя, -

- Привет, моллюски,

привет, креветки, -

хвалёной ку́здре

вогреки, и навеки.

. января 1968

594

Kaко́е крестьянство?!

Кака́ я интеллигенция?!

Како́й рабочий класс?!

Eщё вчера по-чешски:

- Pozor! Pozor!

Сегодня по-русски...

Когда же я буду жить?

Мне уже за тридыать.

Я ошибся!

Мне уже под шестьдесят!

21 aвrycra 1968

Мне говорят:

какая бедность словаря!

Да, бедность, бедность;

низость, гнилость бараков;

серость,

сырость смертная;

и вечный страх: а ну как...

да, бедность, так. 
Кахая мне разница по́хороны или похоро́ны?

Отвезите меня в крематорий,

озолите;

а золу́

- или зо́лу -

высыпьте в мýcópónpóвóд.

I июля 1967

\section{7}

Метисы от евреев очень хороши:

колёсики волос

над круглым барамбуком, тюбики,

бубики, суржики, мурзики,

беличьи, заячьи,

Иван-Израйлевичи.

1.3 декабря 1967

Дык... Тык, пык, мык.-

и некуда, и неоткуда,

и нечего возразить.

Убийственная логика развития

ведёт к развязке жизни и события,

и как бы там ни развозить,

а, рано или поздно, неизбежно следует концовка:

а там, гляди, и „не было“.

$$
\text { "был и нет"; }
$$


Мой язык славяıский - русский. мой народ смоленский, Курский, тульский, пензенский, великолуцкий.

Руки скрутя'т за́ спину. повалят навзничь, поллитровкой голову провалят ничего другого я не жду от своего народа.

II ноября 196.3

679

Если думать только о себе, можно стать доцентом, можно и профессором, можно, наконеll, совсем свихнуться, если только; слава Богу, поэзия, прости Господи, должна быть глуповата (Пугшкин).

2.3 мая 1970, Днепропетровск

Преступление и наказание?

всё в порядке! - лейтенант, повторите ириказание:

- есть, приказано расстрелять;

ни толстовццины,

ни достоевщины,

освежила душу война-военциина:

наградные листы, пооцрения

(крест у них, у нас звезда);

Мне отмщение

и Аз воздам. 
В этой

ничьей деревне

нищие тряпки на частоколах

казались ничьими.

Г. Айги

Протягиваю руку

никому.

Тянусь, но не пойму.

как крынка выползла за тын,

как стало рыхлым и родным

рядно.

4 aвгуста 1970

223

Стукачи.

сикофанты,

сексоты,

Рябов,

Кочетов,

Tимаusук,

я ког да-нибудь всё напинуу

я сведу с вами счёты.

проститутки

и стихоплёты.

Корнейчук,

где твой брат Пол ицук?

Не прощу.

28 декабря 1961

551

И. Холину

Bсего ничего.

А девицы из ВТО

ничевей всего.

$\rightarrow \quad 28$ декабря 1967 
Всё надоело, всё остонадоело. Пустая жизнь, пустой причал, пустое небо. И только глаза завидущие попробуй им, запрети,за каждой девкой худущей срываются, как с цепи.

279

Живу по старинке, читаю Аксакова, малюю картинки конкретно-абстрактные, хочу забыть.

что на свете делается, учу себя ни на что не надеяться.

А на свете зима, и в домах зажгли разноцветные окна, и такие мохнатые по углам фонари, что смотреть щекотно.

27 ноября 1963

691

Солнце - открылось, солнце - закрылось, рассмеялось сквозь палыlы - просыпайтесь! и мы проснулись.

$\rightarrow \quad 5$ aвrycta 1970 
Как дали по мистической суцности мессианства, и вот вам результат:

ни

нейтралитету,

ни

суверенитету,

ни фига нету!

10 октября 1969

758

Увидел ча́ечек, обрадовался:

Евпатория не за горами!

24 апреля 1972

759

После побелки забор как у Янкилевского.

Стена - электролампой - включена.

Кажется, единым махом

нет - и тень -

художник - одухотворил.

21 апреля [1972], Евгатория

760

0 , трепет юности , впервые посаженной на мотоцикл!

О, сдвиги тро́гателя!

26 апреля [1972], Евпатория 
Мы сидели у Айги.

Вы сказали мне: „уйди“.

А Рубина говорила, намекала на Мемеку -

„- почему не погадать хорошему человеку?

надо только угадать хоройего человека;

надо, надо, надо ждать... хоропему человеку.

15 мapтa 1973

782

... маленькая І олова.

как у бедной дебютангки,

той, чья мумия жива...

17 мapra $[1973]$

783

... ну процай покедова, лет через 10 встретимся

на углу Бродского

и Невского...

25 Mapra [1973]

689
... словно снящнйся
другому сну...
Г. Айги

Орудия человеколюбия,

человека лечат,

калечат - подборками,

подпорками цитат:

усни, -

и сны спят.

cחяT

В ночь с пятого на четвёртое. 
В некотором царстве.

В некотором государстве,

в белокаменной Москве краснопролетарской

тридцать лет и три года

жили-проживали

старичок со старуикой в полуподвале.

А на тридцать четвёртый год случилось чудо:

в переулке,

где ютилась их лачуга,

точно вынутые из улья восковые соты,

от лесов освободился дом высотный,

И теперь старичок со старушкой.

проживаюцце в полуподвале,

за окоиком видят Герб Союзный,

за который мы воевали.

Верлибр это рубленая проза.

Строчка-рубль.

А нам не платят ни копейки

ни за прозу,

ни за верлибр.

И рифмы тут ни при чём.

Как слышно?

Перехожу на приём.

10 апреля 1968

У Истории

свон

знаки препинания.

Вся История - на и:

вся - иносказанье.

$\rightarrow \quad 15$ сентября 1968 
Я людей не перевариваю.

Я брожу

как Демон

хмурый.

Только с морем разговариваю.

С морем

и с деви́цей Нюрой.

Третий годик

этой де́вице.

У неё глаза - синицы.

Две мышиные косицы.

И порок сердца.

Mope, море,

море бурное.

Не балуйся, замолчи.

И больное сердще нюрино,

если можно, полечи.

4 мая 1961, Нижн. Кастрополь

769

Товарищ,, а, товарищ,

ты веришь?

А ты -

веришь?

24 октября 1972

770

Ребёнок рисунка:

вроде как машинально, почти по ошибке

художник

нанёс

на холст

смертельный намёк.

2 ноября [1972] 
... а впрочем.

не всё ли нам равно - писать - свободным

или каким-нибудь ещё-стихом

в концентрационом лагере...

3 ноября [1972]

109

Ох и наломило,

намело́

chéra,

навело́ на стёклах ёлки,

насугробило -

и вот - тепло.

Вот и мне тепло,

в моей шинёлке

стёганой.

Зиме - капут.

Скоро-скоро лето переспорит зиму.

Скоро с крыш на землю струйки потекут.

Скоро я свою шинёлку скину.

1957

123

Эх, Мандельштам не увидел

голубей на московском асфальте,

не услышал

шелеста

и стука.

доносящегося снизу,

не взял в руки

сизую птицу,

не подул ей, дудочке, в клювик,

гули - гули, голубица, гули - гули,

умер Осип Эмильевич, умер.

$1953 ?$

(когда ввели голубей в Москве) 
На помидорах - телесные меты.

Дома хозяйка?

С Воздвиженья нету.

День на исходе,

и ночь

на исходе.

Месяц

то всходит,

то заходит.

Kak no уставу,

за старой пущей

с места снимаются

стойла

и сучья.

Крыни кудахчут:

куда бы податься?

Шаnkи

готовы К мягкой посадке.

28 июля 1967

590

Великий Зоченко, как сказал великий Козловский, когда вдымину пьяный бессловесный бас, лопаясb

и ухмыляясь

и подмигивая телезригелям

распространялся за экраном.

Великий Зощенко, великий Хлестаков, великий Козловский,

а бас ухмылялся, хмы, хмы, а бас ухмылялся,

а Юрий Алексеевич приземлялся.

а Иван Семёныч,

а Михал Михалыч,

а бас ещё был пьян да умён.

6 aвrycta 1968 
Серо-зелёное зло

подползло;

проволокло гальку;

стекло хрустнуло;

блеснуло боками:

уснуло.

Трубы дымят - завод.

Трубы гремят - парад.

Ад

или Рай ?

Выбирай

из двух зол меньшее.

Как это просто! -

а мы и не знали

ни о нейтрино,

ни о мирном уране, -

жили,

и умирали,

жили,

и умирали,

жилк...

21 декабря 1967

586

Гром среди ясного неба,

голодному хлеб,

свет слепому,-

Tak

Господа Бога

голос

по беспроволочному телефону,

и пусть это только хохма,

хо-хо, только рифма,-

я гитлеру сто грехов простил:

со мной Бог пошутил!

$\rightarrow \quad 23$ июля 1968 
Хочется написать стихотворение не по замыслам старого времени, a попикассистей, посовременнее,

хочетея

В ямб или хорей

вставить

вечернее огнеоконие, хочется

пабануть

симфамфонию

в сопровождении фонарей.

HO,

уважаемая публика,

поэзия - каверзная музыка;

носится в воздухе,

а в руки не даётся.

\title{
20 ноября 196.3
}

631

Кричи не кричи,

Карачарово ни при чём, оно мне ни к чему:

барачный поэт

Игорь Сергеевич Холин

не тю-тю,

а гу-гу,

то-бишь

ОБМЕН СОСТОЯЛСЯ !

\author{
А я помню \\ этого Холина \\ ещё не Сергеевичем, \\ а Вячеславовичем, \\ и не Игорем, \\ а Петром. \\ Eго фамилия была Чуриканов. \\ $\rightarrow \quad 28$ января и 9 ноября 1969
}


Увоялли бо би́гули карчуна́, и кам чур мазу́рли,

и кам чур

музо́рли,

и гло́кая ку́здра,

и бре́згна, и хна,

ба ка́рчум,

ба ка́рчум,

ба та́рчум -

увояли бо бигули карчуна!

Хаве́й ристапо́рой,

разб́рой сиве́гой

вы га́жите ха́вy

и гажите хе́ву;

зару́ката хо́ма.

да я то и сам -

ба ха́рчум,

ба та́рчум -

и чмо́хан, и чхан,

ба карчум, ба тарчум.

16 апреля 1966

Шёл, нашёл золотник. Первая мысль: мал, да дорог. Вторая: дорог да мал.

Вот так. И у стен есть уши, заткни их.

$\rightarrow$

Безимянный, безымянный палец! На кой ты безымянный нужен?

А из меня кровь для анализа берут.

$\rightarrow$ 
Всё шутки шіучу, никак не вышучусь, nollyчy ещё чуток. хоть чутушечку, чуть дыну, a почутушіу́...

$\rightarrow \quad 17$ июня 1968

Я умираю.

В конце явился Генрих, который бонтся смерти ещё больше, чем я боюсь (моей смерти, моей!)

- Ян, ну как дела? -

и дыllaл

в платок

и в угол.

И Холин, для которого я (как и вы) не существую.

И Кира, для которого я, кажется, мог бы осушествиться, если бы -

- Ян, не умирайте, Maııа вас любит, И Нина Тимофеевна, - совершенно железно! -. умираю, снявши зубы,

и думая,

что я улыбаюсь

вам. 
На похороны приехали

Шурик Черников,

Шурик Компанеец.

Лёвушка,

Бобик,-

три доктора,

один единствснный кандидат.

говорят

- Марике Губергрице.

которого забаллотировали

В Эстонскую Академию наук.

а Петька плачет.

Плачет.

Никог да не плакал.

А ну, у кого там ещё

защемило

B носу?

Сморкайтесь, пора.

Под окном

реактивно взревели

призывные трубы,

и испуганный лось

отозвался

в сосновом лесу,

и мохнатые снежные хлопья

сорва́лись с деревьев,

с зелёных деревьев.

Уже приступают.

Выносят.

Hecyt.

На лестницс

не развернуться.

Толпитесь,

толкайтесь,

спускайтесь живее, живые.

Друзья, у кого там уже защипало в носу?

Сморкайтесь,

сморкайтесь,

на то и даны вам

платки носовые. 
Ну, вот.

А на будушую весну

из-под земли полезет всякая зелень.

Илюиг,

пошевели мне траву,

пошевели траву,

Илюша...

24 января 1965 и 21 апреля 1968

658

Антисоветизм иропекинской клики,

kлевать,

клервеи.

клеветни́ки,

кавычки.

ква́ртал

ковырять,

картавить,

в горвоенкомат.

24 февраля 1970

Встретил Остапа Бендера: он теперь вылитый Паниковский, Да, умершие сравнительно молодыми Иля Ильф и Женя Петров вряд ли могли предвидеть такой конеџ дилогии.

2 июня 1969

625

Вера - в терапию,

вернее - в фармакопию,

вера

не в то,

что дважды два,

и опять же пятью пять,

a,

так ckaзaтb,

в идею!

16 января 1969 
Капитан Чернов

был убит наповал.

От взрывной волны

я свалился в подвал,

и лежу.

и кричу

из подвала:

не хочу, не хочу,

чтобы всех убивало.

И сказал мне

Господь Бог:

- Ну, вот,

вот я и сделал всё, что мог,

а катюши

и танки с водородной бомбой

стройте сами -

по образу и подобию.

7 декабря 1968

645

Все мы смертны, господа следователи преследователи, Сто́я в гробу - что ж я могу

во имя сушестветельное,

прилагательное,

глагол?

Извините, что я старый.

10 ноября 1969

465

И красный не красный.

и празднуй, не празднуй,

и всё оттого что,

всё потому что,

с микитой тошно,

с косыгой - скучно;

и страшно.

9 ноября 1966 
И та же чертовня из-за забора, и та, или не та, коза, или корова, и тёткин говорок (таё-моё); но лейтенант - не тот; тот был майор.

6 апреля 1971

714

Думаете - своабодиый стих свободней несвободного? До этого надо ещё дорасти,спросите у Самойлова.

$$
9 \text { алреля } 1971
$$

Всё реже пью, и всё меньше; курить почти перес'тал; а что касается женщин, то здесь я чнст, как кристалл.

Поговорим о кристаллах.

Бывают кристаллы - Изольды и Тристаны.

Лоллобриджиды, Мэрилин Монро.

Кристалл дерево и кристалл вино.

У нас в университете кристаллографию преподавал профессор Микей, Александр Яковлевич. Его посадили в 37-ом.

Когда его выпустили, он нет не могу.

А вы говорите Лоллобриджида.

15 нюля 1963 
Не говорите мне, не врите, не в ритме дело,

и не в рифме.

а в TOM,

чTO

втравленное с детства

в мозг и кровь

ребёнка:

Партия,

Народ,

Закон -

всё обернулось русской правдой - кривдой!

446

Пришёл рыбак, попробовал удочкой воду.

И сразу со всех сторон налетели чайки.

Десятки, сотни чаек мечутся между морем и небом, как муравьи и муравейнике.

Друг мой, железный ослик, мирно ржавеет на базе.

В воздухе есть ядовитая соль хлористый натрий.

Бог ли её сотворил, или чисто случайно соль появилась на свет - никто не знает. Может быть, Сталин знал.

Ведь не зря, говорят, у Берии были компрометирующие материалы на Карла Маркса.

6 мая 1966, Ялта 
Братіы, что вы обо мне знаете?

Что под носом усы вися'r?

И что я не вашей нации?

И что лет мне под пятьдесят?

Мало,

мало вы обо мне знаете.

А ведь, кажется, чего бы легче бы:

поднимите только ве́ки вечные.

За века́ми.

за ве́ками вашими

cกят

онежские светы зелёные.

братцы мон,

братіы Иванушіки, сестрицы Алёнушки...

21 декабря 1961

\section{8}

Сиена жжёная. ивет ожога.

Налей стаканчик, гамарджоба!

Спасибо девочкам

в цветастых ситцах,

они глазам моим дают напиться.

Мне света солнечная палитра

нужна, как пьянице поллитра.

Спасибо листьям

и траве спасибо

3а то, что-

зелено и красиво!

14 февраля 1962 
Здесь, на плоцади?

При всём салюте?

Слушай,

ты сошёл с ума -

кругом

Москва,

люди,

лошади...

А что нам - люди?

Захотим и будем

сами.

Сам.

Сама.

$\rightarrow$

272 a

Завод, завод, ибо зовётся...

Гудит, как улей, родной завод.

а нам то.........

(Песня)

1

Bcë это

трижды про...

и четырежды пере...

а сколько за это

крови пролито?

Каждое утро

бежишь, торопясь туда,

где, дырку в небе заткнув,

торчит труба.

И каждый вечер,

домой бредя.

чувствуешь: плечи.

А за плечами - труба.

24 сентября 1963 
Здесь,

бельма выкатив,

шиурует План.

Здесь вечный двигатель -

пердячий пар.

Здесь

девки-малолетки

тудой-сюдой

толкают вагонетки

С свинцовой рудой.

Шарашікина фабрика,

трави рабочий класс!

Здесь два христова праздника получка

и аванс.

27 сентября 196.3

274

3

Рано пошабанили.

дома ции не смажены,

курочка в гнезде.

а янчко где?

где бог? нет его,

и винить некого,

сами замесили,

сами

тесто квасили,

сами раскусили:

рано пошабашияли.

I охтября 1963

699

Летите, голуби, летите,

глушите, сволочи...

3 января 1971 
... наука - сука...

13 января 1971

701

... в то утро,

в которос "Балчуг"

звучал, как...

... Шаболовка,

Гомулка...

26 января 1971

702

Далёкое - близкое.

Высокое, низкое.

Широкое, узкое.

Да, русское, русское.

29 января 1971

556

Зыки да рыки.

Рыки да зэки.

Рабочие руки.

Рабсила.

И всё как по маслу.

И всё как по $\mathrm{M}$

no 3

$\rightarrow \quad 19$ марта 1968 
Не Шостакович, так Хачатурян.

Не Ариимович, так Амбариумян.

И с одушеблённым лицом

перед важным - подставным - лицом

проносится Трижды герой труда

академик Андрей Дмитреевич Сахаров.

7 декабря 1970

559

Двуединый двигатель спаренного механизма.

Двузначный, двучленный, сердечные клапаны-ну!

А теперь асинхронно.

теперь асинхронно.

Да,

теперь асинхронно.

$\rightarrow \quad 8$ февраля 1968

60

А ну, толкни меня -

я так толкну, пожалуй,

костей не соберёијь.

Те времена,

когда меня любая гнида обижала,

а я молчал, - те времена прошли.

прошли давным-давно,

что было-всё прошло.

я

женщинам

не уступаю места

в трамвае.

Постоят.

Я сам устал как пёс.

Я хамом стал.

Так, спрашивается, о чём тут хныкать?

Смейся! 
Друзья мои, я отоварился!

Я выбил в кассе жир и сахар!

Я выскочил, как будто выиграл

сто тысяч.

Mre

вышибла мозги

Mосква.

Теперь я знаю, как э'го делается;

берётся человек:

разделывается под орех;

весь в кровоподтеках, весь.

Он мечется между колоннами метро

и карточными бюро.

Он-меченый;

от него отворачиваются товарици.

Но он ещё не вецц -

Он это он.

тогда ему суют талон

и -

я не я, я отоварился.

1946

665

... что в вех таких теней

Высокая одна болезнь

Ещё зовется- песнь.

Б. Пастернак

Де́бет - кре́дит - оборот,

а можно и наоброт,

с прйкупа, -

игра

в самокритику:

мартобря́ на партсобра́

(я вйдел это по телевйзору).

$\rightarrow \quad 15$ апреля 1970 
Xopollo в Mockвe:

у гром

дворники

снег

сграбастали и сгребли.

Под Москвой зима,

а в самой Москве

cher

на грузовиках свезли.

Скоро вовсе отменят карточки.

скоро ландыши булут,

скоро - ласточки,

скоро птичкам ne'rb.

ckоро IIочек не счесть.

только ты, моя душа,

додыши

до поры,

довремени́

до весны.

1946

722

Думал ли я,

что Дриз умирает?

Думал ли Дриз,

что он умирает?

Думал ли он, что Др и 3 умирает?

9 aвгуста 1971

723

ПIОСТОТА СТИХА

была обманчива.

Она была

XУЖЕ ВОРОВСТВА.

14 a8rycta 1971 
726 a

Bсе пицут болышие поэмы.

Только мы с Севой.

30 сентября 1971

726

Некрасов, а, Некрасов!

Некрасов в 3-м классе "B“.

Некрасов

вне классов.

Некрасов, вызови Никитина!

30 сентября 1971

725

Исследуйте меня как космонавта провода шланги

частота строк ин'ервидение завинтить бы голову в скафандр.

17 asiуста 1471

Аполинэру, Холину

Чудаки! - зачем вам дразнить их отсутствием знаков препинания? ставьте после каждой строчки запятую, а после строфы Tочky, и пусть их напlустят туман:

тут обман!

тут антиобман!

20 ноября 1969 
Моя последняя любовь - две свинки.

Одна постарше, другая, хрю-хрю, послаще.

$\rightarrow$

6 aөrycta 1971

608

памяти А. Даньшинна

В день моего племянника,

из глубины души,

мигнули и ушли,

не дотянув до сознания,

два слога молчания:

А накануне,

15 октября прошлого года,

я с ним говорил

по телефону; отличная была слышимость!

19 алреля 1970

653

.Завернувши в карту мира жена мужа хоронила":

русская народная песня.

цена рубль тридцать копеек.

13 января 1970

82

Люблю толпиться в катакомбах нашего метро, где днём и ночью от электричества светло,

где пыль в глаза, но не простая, а золотая,

где - прилетают, улетают, прилетают, улетают,

где можно женцциной роскошной подышать, потрогать женский мех,

и хвостик подержать,

и где, среди живых существ любой породы

случаются и генерал-майоры.

$\rightarrow$ 
656

„... законный вопрос; а не допустил ли Тютчев метрических погрешностей, не „обсчнтался“" ли?"

С6. АН СССР „Теория стиха“

1968 г., стр. 1.37

Тютчев...

обсчитался!?

- ударный, безударный ударный, безударный, слог, слог, слог...

Слава Богу, академик Колмогоров внёс ясность, да и, само собой, Леонид Иваныч помог.

22 января 1970

693

Никак не запомню что я старик

( старик - такое амІллуа ) - никак никак не заломню.

6 октябя 1970

517

Коробка скоростей.

Коробка скоростей.

Барабанные перепонки гусиных лапок

фиксируют:

- короткое!.

- короткое!.

- курцшлюсс !

Водитель водит носом по стеклу.

Кузнечик в кузов пуза уложил

окоченевшие конечности караульного начальника.

Карнач! Карнач! Карнач! 
Снабженцу, исполняюाјему обя:занности литератора Льву Абелевичу Влевицкому

думается

(вы себе представляете - ему - лумается!): если слова не такие, каким Лев Абелевич лично обучён, значит. они случайные.

Желудочный спазм

не позволяст мне касаться долее

Льва Абелевича, со Львом Абелевичем, обо Льве Абелевиче.

9 апреля 1968

425

Пересвоилась

с вер60ха на глюсгарь

глОкая кУздра

гор6Окая кУздра.

ЛЫцет и Яıит. за кИрды и хухря, 6Окра за 6Окром, а то и бокрят. А понадъЁрхом, увЕрой покрЫ, глУкают 6Окры магЕры и гры

\author{
Вариант \\ А понадьЁрхом, \\ увЕрой покрЫ, \\ жлЮкают 6Окры \\ мажЕры \\ и жры.
}

29 апреля 1966, Ялта

730

Ваньке дали 8 лет!

Ивану 8 лег? - за что?

За то что якобы Иван Андрейч...

Но это ведь за в д домо е !

22 октября 1971 
Который год

- помилуй бог! -

как ныне сбирается вецций Oлег,

и Спящая Красавица

спит не проспится...

24 октября 1971

681

Дорогой Матусовский!

Дорогой Хелемский!

Дорогой Юикин, Вак Флегетонович!

Это было недавно,

это было давно...

Все встают.

Bce nоют.

12 июня 1970

677

И Мошкин.

Национальность - нацмен.

Нюхая розу поцаралал нос шипом.

И теперь бережёт себя для чего-то более, для чего-то менее.

21 мая 1970, Днепропетровск

651

Поэзия - не пророчество, а предчувствие.

Осонанные предчувствия

НЕДЕЙСТВИТЕЛЬНЫ.

21 декабря 1969 
Уничтожаю.

Этого не жаль.

И того не жаль.

Ничего не жаль

cвoero.

И не почему-нибудь,

а нипочему.

11 февраля 1971

705

А покамест работа мысли

дос'гавляет эстетическое удовольствие, давайте прикинем: что́, е́сли обратиться К области совести?

/1 февраля 1971

644

Как я познахомился с АЯ̆г в музее Маяховского летом этого года

Девять двенадцать - везде-ежедневно-успею.

привет от Бурича!

Бодрый, еще не горбящийся старичок,

я пришёл,

присел;

Айги,

помоги,

помилуй Бог,

бриковед,

дай перевод.

вуд вуд,

по-товарищески,

по-чувашски.

Так п познахомился с АЯ̆и в музее Маяковского летом этого года. 
Коль скоро,

прежде чем, поскольку, не так чтоб, именно, 3aтo, как будто, вследствие, и только, тем более, что ни за что, но лишь, ввиду того что, и6о, едва-едва, и либо-либо,добро бы, ежели кабы, равно как, нежели, дабы!

1958

230

Кончается наша нация.

Доела дискриминация.

Все Хаимы

стали Ефимами,

а Срулики -

Серафимами.

Не слышно и полулегального галдения

синагогального.

Нет Маркиша.

Нет Михоэлса.

И мне что-то нездоровится.

$\rightarrow \quad 8$ марта 1962 
Tак что же - стать советским Фетом

и наслаждаться светом, цветом неба?

Но, во-первых, человек

сейчас на это и не смотрит,

а смотрит в землю.

Во-вторых,

Фет, как-никак, был крепостник,

а я, я? - чем я обеспечен? Чем?

Я был из тех - московских

вьюніов, с младенческих почти что лет

усвоквших, что в мире есть один поэт,

и это Владим Владимыч; что Маяковский -

единственный, непостижимый, равных - нет

и не было;

всё прочеe - тьфу, Фет.

242

Вы ошибаетесь,

они

не антисемиты:

все эти -

Кочетов,

Кречетов,

Марков A.,

Марков Г.,

бодряк Софронов

и тэдэ,-

всё это

члены союза советских писателей,

члены гильдия,

инженеры человеческих душ.

А вот за Эйхманна не поручусь.

Эйхманн не из нашей организации.

$\rightarrow \quad 15$ декабря 1961 
Ну, ладно, семь бед-один ответ.

Мне было 7 лет,

ког да Гумилёва в заневском застенке

поставили к стенке,

пустили в расход.

и были декреты,

и не было хлеба,

кровавое небо,

багровый восход!

19 февраля 1962

241 a

Вместо сока из томата

льётся мат

из автомата.

- „Славься, славься,

русский народ",

$-, y, 6$

ё $\quad$ в por".

20 мapta 1962

647

Вечер был,

сверкали звёзды,

рано было,

или поздно,

не полёг,

не полёг

зимостойкий дриз,

улетай же, мотылёк

мальчик, застучись...

Октябрь 1969 
Уважаемые дамы и господа.

братья и сёстры,

то-есть вот когда приспичило,

видать, прищучило,

чо насцы в глаза - всё божья роса,

что и Ючкин Вак Флегетонович

И. о. Виссарионович.

2 нюля 1970

612

14 апреля

Маяковский

покончил жизнь самоубийством.

А жить

становилось лучше,

жить

становилось веселей,

поэтому

смерть поэта

устраивала генсека.

26 ноября 1968

608

Я чужой тебе,

и ты чужая.

Часто думаю,

соображаю:

может,

где-нибудь у Миссисили

я бы жил с тобой

как мотоцикл.

2 ноября 1968 


$$
\text { И. Холину }
$$

Дом мод: моддо́м.

С дудьём.

с мамадьём.

с били́биным пинига́сом,

и с дрёсом,

и С тра́сом (во чтó?

Моддо́м.

в пиридо́н-перево́д!)

Дом мод

Іле́мени ка́ждый ва́жный.

$$
2 \text { мая 1966, Ялта }
$$

626

Пришёл ко мне товарищ Страхтенберг.

Какой он старый, просто смех и грех.

товарищ Страхтенберг, товарищ Мандраже, садитесь; - не садится; я уже...

15 января 1969

6

Вчера, опаздывая на работу, я встретил женщину, ползавшую по льду́, и поднял её, а потом подумал: - Дyрак, а вдруг она враг народа?

Вдруг!- а вдруг наоборот?

Вдруг она друг? Или, как сказать, обыватель?

Обыхновенная старуха на вате, шут её разберёт. 
Всё законы, всё занюоры, огорожи, забобоны, то и это под запретом, шёл я с братом, и заплакал.

15 декабря 1968

За 20 лет, пересверкнувших молниями окна, как изменился свет! Нет Мопра, и нет Догіра, нет Вцика, и Лиги Наций тоже нет:

и лаже „ЦКК грядущих светлых лет“непостижимы, аки обры.

13 апреля 1950

526

Что это значит?

А ничего не значи'.

Абже, да как же?

Всё также, манюня, всё также.

Так же, как раньше?

Да, мамочка, так же как раньше:

может быть, Макбет,

a, может быть,

aбжe,

да бабже.

$\rightarrow \quad 25$ июля 1967 
Слушай сказку, детка.

Сказка

опыт жизни

обобщает

и обогащает.

Посадил дед репку.

Выросла - большая пребольшая.

Дальше слушай.

Посадили дедку за репку.

Посадили бабку за дедку.

Посадили папку за бабкой.

Посадили мамку за пагккой.

Посадили Софью Сергеевну.

Посадили Александру Матвеевну.

Посадили Павла Васильевича.

Посадили Всеволод Эмильевича.

Посадили Исаак Эмануиловича.

Тянут - потянут.

Когда уже они перестанут?

660

Не шапируйте их, не провоцируйте:

каждое напоминание

о нашем существовании

это уже ноль целых пять тысячных

подготовки погрома.

15 марта 1970

574

Лёгкие на помине,

а в поминании нас нет,

В святиах нет, на афишах, на обложках нет.

Мы-неупоминаемые.

24 апреля 1968 
Говорит Москва,

Новости медицины,

яйца реабилитированы,

виноват caxap,

он не наш кадр.

сказал Я.К.,

кто против,

кто воздержался.

принято единогласно.

25 ноября 1968

603

Огни над окнами

в едином лозунге.

Знамёна подняты.

Знамёна в воздухе!

И их количество

переходит в качество,

как электричество

в очковтирательство.

12 октября 1968

646

Ни малейшего человеческого оттенка

в словах.

Безаппеляционно

и безынтонационно.

Даже если это правда

это ложь.

Ложь взад! - как писал великий Зощенко.

10 нюня 1969

682

Бурные, долгие годы не смолкающие аплодисменты. 
663

\section{Христианин}

Отдам азя́м ю́ду.

А сам?

Сам уйду в чём Бог дал -

в бечёвочках.

28 мapra 1970

662

Ну, вот и доро́га.

A по доро́ге шиба́рики.

А под воро́тней муры́

А в недалёком городе Костроме пустырь мастерови́т: крив да гараж.

28 марта 1970

174

Всё, что кажется так важно

и навек, навек, -

всё неважно,

всё бумажно,

Bcë

сойдёт на нет.

12 января 1960

175

Я хорошо, я плохо жил, и мне подумалось сегодня, что, может, я и заслужил

благословение господне. 
Просыпаешься среди ночи

с сердцем, бъюцимся изо всей мочи

и с единой мыслью:

свершилось!

Вдох:

свершилось!

Выдох:

свершилось!

Вопль:

свершилось!

- Да что с тобой?

४ro ты?

Что случилось?

- Забыл... приснилось...

13 февраля 1959

560

Одна поэтесса сказала:

были бы мысли, а рифмы найдутся.

С этим я никак не могу согласиться.

Я говорю:

были бы рифмы, а мысли найдутся.

Вот это другое дело."

У февраля 1968

- ничего подобного: это одно и то же.

524

Жил в Ростове человек - мальчик Юрочка.

Он от солнышка

до подсолнушка

всё на свете превзошёл,

всё до зернышка.

Я хотел бы стать таким же, как Юрочка. 
Хочу ли я посмертной славы?

$\mathrm{Xa}$,

а какой же мне ецё хотеть?

Люблю ли я доступные забавы?

Скорее нет, но может быть, навряд.

Брожу ли я вдоль улиц шумных?

Брожу

почему не побродить?

Сижу ли меж юношей безумных?

Сижу,

но предпочитаю не сидеть.

20 июля 1967

469

В апреле

земля преет,

баня парит,

баня и правит.

Tak вяжи

гужи

пока свежи!

Да не бей

Фому

за Ерёмину вину,

нынче хривда

только за морем кричит,

а у нас в Москве

В лапти звонят:

пожалел затылок,

хлобыстнул в висок.

11 декабря 1966

Этот стих весь составлен из русских пословиц 
Интенсивно

и формулированно

думаю 1/2 часа в день:

когда утром бегу на работу.

Содержание

может быть бессознательным.

Сознательной

должна быть форма.

Да,

но как же тогда

обезьяны (которые малюют)?

Ответ:

Tak жe,

как соловьи (которые поют).

Поэзия,

опрозаквайся!

Проза,

докажи, что ты не верлибр.

9 aвrycta 1964

581

Скуда взято, что водка сладка?

Сладко красное вино, да больно дорого оно, да привезли врачам больного из Ростова - Таганрога, те всё пишут, пишут, пишут, а больной уже не дышит я в столовой заказал жареную ры-бу, благодарность написал

В жалобную кни-

гу, гу, ни гугу, запрягу телегу, в Америку поеду.

$\rightarrow \quad 27$ июня 1968 
Сколько ушло, отшумело, отпело, полвека, век?

Прошлого нет.

Но и - непрошлого нет.

Было - даёшь!

стало - давай-давай.

Было - долой!

стало навеки веков.

25 марта 1968

643

Недавно тили-лили - дудная (чудная) Галя Гладкова говорила обо мне с новым главным редактором "Малыша" вроде бы так:

- Знаете, товарицц Главный, он очень русский человек, Яковин Абрамчик. Такой русский, что уже даже почти украинский.

5 ноября 1969

661

Один известный поэт (угадайте кто) сказал другому известному поэту:

- Если стихи осознаны как проза, они много теряют в монх ушах.

15 марта 1970

429

Вчера я опять написал животрепещущий стих, который оправдал мою жизнь за последние два или три года. Во имя отца и сына и святого духа оживела летошняя муха, не летает ещё, только ползает полозом по газетным полосам, по колхозам, по соцсоревнованию, по Всемирному Сосуществованию. 
Я теперь работаю в Главке -

Глав-

$$
\text { ynp- }
$$

kyp-

лапки.

Главное дело-дело есть:

для дальнейшего

подъёма

куроводства

обеспечить

оборачиваемость

оборотных средств

Іроизводства

средств производства.

27 октября 1966

\section{9}

Все думают одно и то же. и говорят одно и то же, но говорят одно, а думают другое.

$$
16 \text { октября } 1964
$$

Рыбы дышат жабрами, а автомашины электрическими лампочками.

Aeryct 1964 
Тах быстро,

так быстро бегут облака,

так быстро,

так пусто вокруг,

a закат

так низко...

14 июля 1968

154

Какой-то закат - особенный, всё небо располосовано,

все краски соінли с ума,

всё - атомная война - всё -

но не надо вслух;

опасен даже звук;

фу-фу - и свет потух,

и след простыл...

Сентябрь 1958

247

Схлестнулись с лириками физики.

взывают:

- Шизики, изыдите!

Повыздохли в Россия мамонты, телевизоры кругом,

и граждане все стали грамотными, все знают "фидер" и "трамблёр“.

I ноября 1959 
Савва, помню, Голованевский

с Нэськой дружил,

с балагулиной Нэськой.

Это была такая Джина Лолобриджида,

такая Джина,

такая Мария Маг далина,

Такие

библейские волосы были у Нэськи,

были... Вы понимаете по-немецки?

20 aвгуста 1973, Днепропетровск

799

... комендант наук...

20 aвrycra [1973]

800

... а укра́инцы, оказывается, укра́инцы...

20 aвгуста [1973] 


\section{ИЗБРАННОЕ 1974 Г., ТРЕТИЙ ТОМ}

408

В воскресенье

каплет с крыш,

каплет с крыш;

а во вторник

так и брыж,

так и брыжжет во вторник.

Только это не весна:

до весны ещё

весьма

и весьма.

27 декабря 1965

287

Вот он, тот дом,

где мы жили,

и не жили,

спать ложились

и вставали,

и валялись на диване,

и

„неоднократно

выпивали",

тот самый дом,

те же окна,

даже

штукатурка та же,

тот же за окном

приёмник.

Дом, дом, дом!

Дом

Hac

не помнит.

25 ноября 1963 
Гena

усыновил своего сына,

установив в сыне

свои гены.

Октябрь 1969

Знаменитый Сказочник

бороду носил.

Встретил его

Ванечка,

встретил и спросил:

- Знаменитый Сказочник.

хотя и молодой,

что у тебя

нового

за старой бородой?

Октябрь 1969

649

Выскажу вам

мысль-

на всю

Хватит

жизнь:

глупо стесняться

если

глупости снятся.

$\rightarrow \quad 24$ ноября 1969

790

... гиперболы, метафоры, литоты, вторичные половые признаки Поэзия...

5 июня 1973 
Вот и вышла

новая книжка.

Книжка вышла,

хотя и не вышла.

18 июля [197.3)

792

Муха влетела в окно.

Во кино!

По комнате летает муха.

Она садится на конверт.

Увы - обратный адрес неразборчив

и горьковат на вкус.

Как жаль! Так жаль!

31 июля [1973]

623

Чудной денёк!

Пришёл

и - лёr.

Toго коснусь,

к другому сунусь,

ленюсь,

бранюсь -

впадаю в юность.

13 января 1969

716

A всё-таки

крупная женщина

это вам не мелкая женщина.

$24 \mathrm{MaA} 1971$ 
С трудом

сілюнул.

Потом

долго

смотрел в урну.

О чём он думал?

3 июня (1971). Днепропетровск

718

Каменные бабы, каменные прапрабабы,

брюхатые, с обвислыми усами;

вот одна кирная баба

припустилась на базар

и, скажн, чего ей надо,-

телевизор чи сервант!

7 июня 1971. Днепропетровск

\section{4}

В Париже скончался некто Цадкин, Цадкин, никто иной.

А сколько статуй на Новом Арбате, где СЭВ и видеотелефон!

$\rightarrow \quad 8$ декабря 1967

694

Худолних Володя Яковлев

То есть, до чего

поразительно:

вместо приблизительной точности

точная приблизительность.

8 ноября 1970 
В полночь

на Пресне

переменились масти:

светлые - погасли;

тёмные - воскресли;

что ж ты,

товарищ,

в душу мне фары пялишь?

6 ноября 1963

582

Сегодня 17-ое июня.

Никто не родился и не умер.

По этому поводу

скажите мне, кто-нибудь,

живут ли ещё в нашем городе

еврейские дамы

с большымы полямы

и русские горькие мамы?

1 июля 1968

219

\section{Предыстория III}

Bot

и месяц прошёл.

Месяц, ках мы опустили в яму

маленькую старушонку.

Чужую.

С поджатыми губами.

Которая

в жизни была совсем другая.

Которая была

наша мама.

$\rightarrow \quad 10$ ноября 1961 
Луна сегодня подрумяненная, напоминает Северянина.

Ведь есть же, я читал, есть девочки в четырнадцать, пятнадцать лет.

Я всё надеюсь на что-то лучшее, на дело случая, на март-апрель.

10 января 1960

635

Мы уже были за Саном.

В соседней газете

был такой литсотрудник - некто Смульсон.

- Не смульсоньте мне газету!орал в телефон Лев Захарович Мехлис.

До Победы

оставалось ещё километров 700.

21 января 1969

489

\section{Илюшке три дня}

Полетели письма, тю-тю.

Их уже теперь не воротишь.

Зря ты, парень, меня торопишь;

захотю - и сам улетю.

Мама,

мне ещё и годиха нет.

"Через месяц мне будет пятнадцать".

Вот я, братцы, и дед.

Начинается

дедство.

и бабство. 
Нет, Марцинковский не тот человек.

И Вервинский не тот человек.

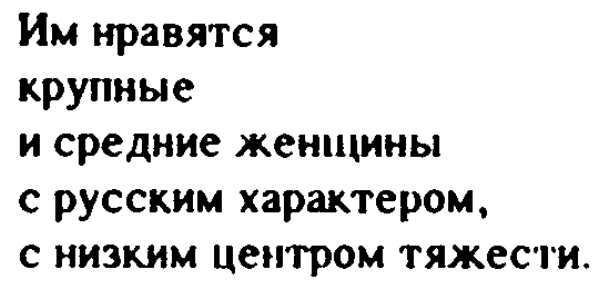

Им нравятся

крупные

и средние женццины

с русским характером,

с низким центром тяжести.

А, вы думаете, Ли́писиц - тот человек?

1 декабря 1969

366

Захотелось всякой всячины:

чец из крапивы;

пива - чешского пива! -

сладкой гусятинки...

Я 6

лучку покрошил

во всю эту

страву...

Я 6 слезами подсолил...

10 июня 1965

382

Я рифмую дождь и плащ.

А моя жена

срифмовала

плащ

и зонтик.

Что ж? - может быть она

права.

9 aвrycta 1965 
В Рязани

пироги с глазами,

их едят,

а они глядят.

Не хочу пирогов с глазами,

не хочу в Рязань,

хочу в Саратов.

У меня в саратовской

курной избе,

в зыбке-корыте,

девочка моя,

веточка моя,

моя эвакувыранная.

У моей у дочки - глаза-кружева́.

Круглыми глазами

провожала меня.

Не хочу пирогов с глазами,

Не хочу Рязань,

хочу Саратов.

1942

427

Ёжки - миёжки, пиёмные фуёжки!

Ай, Как a-я-ой, ая-ей, нияя-ей, как пияккет, как мия́кнет, и выхо́дит:

$$
\begin{gathered}
\text { Дy-га-дей! } \\
\text { (Гага, 2га) } \\
\rightarrow \quad 3 \text { мая 1966, Ялта }
\end{gathered}
$$

๑Произносится 


\section{День рохдения}

А на улице весна.

Играет в цурки пацанва.

И направо, и налево -

и, какие девочки.

Девочки, подвиньтесь,

Veni, vidi, vici!•

Я Иван капитан

всех девиц повоевал.

Фиг, фиг, фига с два,

ты, Иван капитан,

низенького росту -

метр девяносто!

А на улице весна, тротуар высох.

Скоро выбрызнет листва изо всех сисек.

- пришёл, увидел, победил (лат.)

\section{7}

Как оживляешься, ког да вспоминаешь (и через столько лет!) румынок, или там, славянок. А вспомни-ка Смоленск!

Как ты лежишь в кювете, и при каждом

взрыве

вздрагиваешь с головы до пят, а м03r срабатывает безотказно:

„не в этот,

в следующий раз..."

„не в этот, в следующий раз..."

„не в этот, в следующий раз..." 
Крячная, мрачная мымра

отмочила хохму,

и мир - ахнул:

- нимфетка! нефертитка!

Но чацце бывает наоборот.

$$
2 \text { asrycta } 1968
$$

У всех знакомых

Есть семья.

У насехомых

Есть семья.

У Стрекозы,

У Муравья -

2 Я.

3 Я,

4 月.

Один Паук

Живёт 1,

Хозяин

Этих паутин.

618

Человек-человеку-внук

каблучками туп-туп,

сапожками рып-рып.

Не сердись на него, старнк.

Внук говорит: бию́к.

Говорит: сабаба.

А дед ему читает Сапгира и Гирсапа,

Пускай ребенок спит.

Пускай ему приснится

жар-птица или рыба-кит.

2 января 1969 
Все в капроновых болоньях

- поголовно! поголовно!

Я согласен быть голодным, но в капроне, но в болонье,

я согласен быть голодным, не иметь автомобиля, но в болонье, но в болонье!

В крайнем случае - в Севилье!

21 апреля 1966

66

Всё начальнички, всё инженеры, техники об рабочем беспокоются. помочь стараются, чтобы лишний грош не заработал зазря, чтоб не выкарабкался бы из нужды.

Всё разумнички, всё научные работнички. счетоводки, милая, да секретаря над народом разоряются, медалями тешатся.

а и пуще всего - жиды.

599

Мама

улыбнулась на ребёнка;

а Иван-Мефодий-Карл Аронович:

- Слушьте, да это же неграмотно,и пойдёот нудить грамматику!

17 сентября 1968 
601

Все мы люди,

все мы человеки, у того желудок,

у той кишечник,

все мы

сисю хочем,

хохочем,

и плачем,

а чего мы значим,

промежду прочим?

1 октября 1968

249

Я сегодня - только вышел из вокзала, только было вынул пачку закурить,

а голуби как маханут,

и вот, пожалуйста,

обос... меня какой-то паразит,

на плечо и сзади

весь пиджак изгадил.

Ладно,

это будет, чёрт возьми, наука,

я ещё не так их, гадов, шугану.

C....нy ka

я

на Нородома Сианука,

на Уну, Насера и Неру с...ну!

19 сентября 1961

766

Кто за Фишера?

Всякая шушера.

А мы за русского. за Васю Спасcкоro.

II abrycta 1972 
Как странно, что все они поэты -

и Злотников, и Передреев, и Горбовский,

и Туманский, и Подолинский, и куда,

куда вы удалились, этот, ках его, Иосиф

Бродский.

II сентября 1972

768

Бывает стих говорной.

Бывает напевный.

Покойный Митя

писал

писклявым стихом.

24 сентября 1972

730 a

Ваньке дали двадцать лет!

Ивану двадцать лет! За что?

За то что, якобы, Иван Израйлевич...

Asrycr 1972

765

... Потерявши невинность

на грядке укропа

няня поступила на работу

в Пункт сдачи стеклотары,

а рядом -

попал в перетяжку -

трепал деревяжку

Kapn Рябов...

Без вести пропавший...

Человек-сын-божий...

Ваня Пулькин, еснуй

посмертно...

23 мюля 1972 
Ilaрень, тюха-матюха. неземные глаза.

помниіньь, парень. Makyxy, жмых, nо-русски сказать?

- На дворе тихо-тихо, месяц, словно слеза. Я болел вшивым тифом, я забыл все слова...

\section{7 ноября 1961}

669

В чём

смысл Поэзия, если не в том, чтоб жить не залеживаясь (часóв в чác стó!)

Опять же, промежду прочим. как Двушккин сказал заправят горючим и прысь - в засол!

21 апреля 1970, Ялта

Все цитаты - и верные, и перевранные - из П.А.

735

...и-ложечкой- с о в е т ский чай, атосалфетку почитай на сон гряду иий, четырехстопный ходасевич... 
Владька,

Володька,

Владимир приходь, композитор,

рвани́ пофигнее:

без кpacoK

набросок

не бросок.

19 апреля 1971

128

И чем плотней набивается В уши, чем невыносимей дерёт по коже, тем лучше, говорю я, тем хуже, тем, я вас уверяю, больше похоже на жизнь, в которой трепет любовный сменяется скрежетом зубовным, а ритм лирического стихотворения не криком, так скрипом сопротивления. хрипом...

545

Благословенно злополучие. избравшее нас между народами земли.

На улищы! На улицы!

Станцуемте!

Споёмте!

Восстанемте из мёртвых!

Гит Йонтыф!॰

Гит Йонтыф!

Гит Йонтыф!

- С праздником! 
Чем дальше к старости и к смерти (алаверды, алаверды), тем ближе плач в Генисарете и волили Синей Бороды:

$$
\begin{aligned}
& \text { - жили не мы - } \\
& \text { - мы не жйли - } \\
& \text { - нас женили - } \\
& \text { - нежели вы - }
\end{aligned}
$$

$$
19 \text { мapra } 1968
$$

80

Не замазывайте мне глаза мглистыми туманностями. Захочу - завьюсь за облака. Захочу - к млечным звёздам улечу. Захочу - ничего не захочу.

Ибо мысль - мысль арестовать нельзя. милостивые товарици.

462

Помню ЛЦК - литературный центр конструктивистов. Констромол - конструктивистский молодняк.

Помню стих: „в походной сумке Тихонов, Сельвинский, Пастернак“".

Зэк был констрнком, но с новолефовским уклоном.

Как никак, а без Маяковского никак.

Зэк был зэк, и по естественным законам зэка кончили в колымских лагерях.

Помню ЛЦК - литературный центр конструктивистов.

Констромол - конструктивистский молодняк.

Помню стих: „в походной сумке Тихонов, Сельвинский, Пастернах".

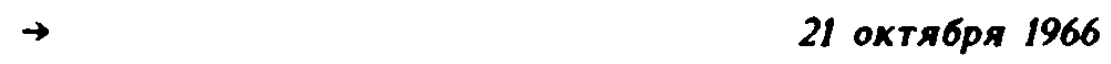


Стихи! Стихи!

Среди трухи - стихи!

Те самые - те, знамые-незнамые,

$\mathrm{Te}$, на ухо названиваемые,

откуль-докуль не спрошенные -

воскресшие!

проросшие из прочилого!

13 января 1966

95

Один идейный товарищ

жаловался мне на другого:

„Подумать, бе́з году неделя в гильдии, и уже такая про́блядь, такая пробблядь!"

На что

беспартийная сволочь,

живущая смирно впроголодь,

я только пожал плечами.

0, совесть

нашей эпохи,

будь оно проклято!

72

Ишь, щучье веко,

ишь, чванное идолище,

весь свет ненавидящее

чучело века,

4y-4y,

рассыпься,

сгинь с глаз навсегда.

Товарищи,

гра́хданечки,

господа,

ищу человеку! 
В закрытой лаборатории

сижу

за секретным отчетом.

И глупые мысли - одна за другой -

тревожат о чём-то.

Bot

вёрткая птичка,

головкой направо,

головкой налево,

то сверху глазок, то снизу,

прилетела, опять улетела.

И-дикая мысль-нет, это не птица:

японский биолог

ирисел

ознакомиться с грифом „секретно“

на подоконник.

Присел, профессорский хвостик почистил, налево, нанраво.

Tеперь всё высмотрит, сфотографирует

n-

к себе, в Иокогаму!

90

Ха, ты еще не умер. товарищ Юмор?

Курилка, как ты перенёс Нарым?

Не помнишь? Всё, что было, всё забыл!

Тебя философы трясли как грушу, следователи вынимали душу:

„Врёшь, не уйдёшь от Берин, сгннёшь в тюрьме..."

Да ты и верно ведь, ненадёжный элемент.

И вот - живой!

Весь в шрамах, ссадинах и синяках,

то Дон-Кихотом оборачиваешься,

то Санчо-Пансой,

и в эпоху позднего реабилитанса

читаешь

свежие постановления ЦК. 
И хоть слушаещь их вполслу́ха. рапортичек этих слова, от Великой Показухи засупонивается голова, Tak, что сам начинаешь верить, что до цели - подать рукой. Так веди нас, товарищ Зверев (чем он хуже, чем любой другой!)

376

А кому - на, на, а кому - ні, ні, а Миколу Хвильового розстріляли, чи ні?

А кому та́торы, а кому л́́торы, А Бориса Пильняка К ёхсиной матери?..

2 июля 1965

86

Сяду, радио выключу. За день - выколочу сердце; сердце, помолчи; а в мозгу точь-в-точь морзянка:

$3 y-3 y$, резолюции, реорганизации, репарации, промкооперации, Боже, какого говна только полна голова! 
Я завёл себе забаву - от скуки.

Я теперь не оставляю окурки под столом.

a -

собираю их, сортирую, скЈадываю на подоконник.

Вечером - часам к девяти - десяти К моему окну подкрадывается фриц из лагеря военнопленных.

Минут пять или шесть он стоит навытяжку - отдаёт честь. Я делаю вид, что ничего не вижу. Ничего не вижу, ничего не слыш...

A!

так вот вы какой. господин Мышь! Господин Фихте! Господин Ницше!

Мгновение останавливается.

Мы смотрим: он на меня; я на него.

Потом я отворачиваюсь.

Больше ничего.

1944, в Германии

68.3

Представь себе - в доме ВХУТЕИНа, где Фёкла Борисовна и тень Давида,

такой гаму́ля-тышлере́вич Куперман, такой миле́ля, не просто травящий, а кислотой медь, напомнил мне, что всё непоправимо. 


\section{Иннокентия̆ Анненския}

Мелко, мелко, как из сита, $B$ тарантас...

\section{И. Анненский}

Что-то знакомое... только забытое словно дождь косой плетень

(Боже! тень с косой...

пле... сло...

день не дожит...)

и сладок Анненскому запретный глод.

15 апреля 1970

\section{6}

Давайте, братцы, поннтеллигентнее.

Давайте обмениваться комплиментами. Давайте обманываться.

Иван Израилевич, вот э'го номер, нивроку. здравствуйте, взял и помер, большое несчастье для Розы, такой мочевой пузырь - это козырь. Давайте забудемте. Давайте будемте.

9 октября 1964

380

Я любил одну единственную женщину. Любил как тучку быстротечную. Я любил её за узенькие брови и за груди-фунтики, такую худенькую. За глаза на букву Б: бнрюзовые.

8 мколя 1965 
Я ие люблю всезнаюцих,

В знании погрязщих.

Предпочитаю

иіцущих

(,ищучие - обрящут“),

- ицучикх,

а пе блешучиих

званиями и степенями

в обществе по распространению

всяческих знаний.

Я,

хоть и сам в этом

обицестве

числюсь

и мыслюсь,

предпочитаю

ищуцих

Иицущие да отыцут!

250

Чьё-то дыханье

у самой щеки,

волосы ластятся,

льются.

Сниться

проклятые стали стихи,

а наяву

не даются

в руки,

истаивает синева,

перестилавшая стих мой,

и обессмысливаются

слова,

бывшие

ритмом

и рифмой.

II сентября 1962 


\section{Поэзия}

Я вам говорю: чудес не бывает.

Меня

ветрянкой называют.

А я не ветрянка,

a Чёрная Оспа.

Когда вы поймёте, будет поздно.

13 января 1969

564

\section{Платоновское}

Не слышно ржущих голосов

родных обобществлённых лошадей.

Захрыв глаза, чтобы видеть Бога, о чём поёт душа

травосея

и хлебороба?

0 ннх,

о них,

о ржущих голосах

родных обобществлённых лошадей!

26 марта 1968

Незаменимых нет.

О да, незаменимых нет.

Незаменимых нет:

есть заменители.

Заме́ним Бабеля?

Заме́ним.

А Зощенко?

И Зощенко.

17 апреля 1968 
„Ник. Котенко“ - ник-то:

литрецензент у покойного Поповкина.

За исключением - естественно - гонорара

исключительно любознательно

проявляет законный интерес

$\mathrm{K}$ вашей национальности.

Зеленоватый.

Вышмыгнул из носоглотки.

9 апреля 1968

563

Разучившись мыслить

(в силу прогрессивных актов)

в силу фактов

(объективных,

субъективных

и декларативных)

веря и не веря

(принципы революционера)

я хотел бы

вскрикнуть,

но не в силах даже пикнуть.

25 марта 1968

579

Орган слуха

и орган нюха

ведают

расположением духа,

а для брюха - краюха,

жуй. да поживай,

кого следует, уважай.

$\rightarrow \quad 22$ июня 1968 
Кто помнил,

того зарыли,

a Mbl,

а мы забыли

о Тайне

открытых процессов,

когда не доцент,

не профессор,

не вырванный с мясом

крестьянин,

a

К аменев,

Р ЫKOB,

Б ухарин,

кто помнил,

того зарыли,

а кто забыл-

в Нарыме.

7 декабря 1967

605

В магазине канцелярских принадлежностей, завязав платочек узелком,

с подобающим усердием,

с прилежностью

заправляюсь

канцелярским языком.

Ловко колют, ловко шьют

скоросшиватели,

шьют, и шьют, и шьют дела.

На боку Портфеля-кожемякина

промокашка

промокашку родила. 
Мне надо забыть,

понимаете,

мне надо собраться с силами,

чтоб вспоонить,

чтоб вызвать в памяти

BKyc

К монументальной живописи.

О как они иенавистны мне

все эти

золотохмурыс

ломброзорожие висельники, лишённые чувства юмора!

1955

591

Для меня, для горожанина, для, тем более, южанина,и ромашки-аромашки, и фиалки-фимиамки, и акация - Божья Мати.

Христолюбивое воннство. распика́сссившее наши душии, иизкий тебе, земной поклон от Самиздацких поэтов, наруиителей прав. потрошителей слов.

$$
10 \text { aвrycta } 1968
$$

667

Памяти

Сутйн я, или Су́тин, не меняет сути, но я живу в Париже и слышу то, что вижу.

$\rightarrow \quad 15$ апреля 1970 
606

Bc. Некрасову

Кончились морозы.

Лужи

лижут снег.

И, кряхтя, колхозы

затевают сев.

- Сева.

Сева,

Сева.

не смотри

на север,

на юr

посмотри, -

снуют снегири.

31 октября 1968

34

Деревьями не интересуюсь.

Наверное, как вы

на их

стволы и листья -

я смотрн на вас самих.

Удачно. То есть, до того удачно -

пе́редано движенье мынц.

Лицо как бы одухотворённое.

И даже

просвечнвает какая-то мысль.

Смотрите - он скручивает сигарету.

Oro, oro,

облизывает языком.

Что-то рыгыгы, облокотясь, соседу.

Затягивается. Выпускает дым.

То есть, у него и дырочки в носу есть.

Он почти как человек. Почти.

Как дерево. Деревьями не интересуюсь.

Наверное, как вы

на их

стволы и листья

я смотрю на вас самих.

$\rightarrow$ 
Неохота мне больше ишачить.

Ноги пухнут, грудь боли'т.

Я возьму себе месячный отпуск

и махну из столицы на юг.

Много есть привлекательных женцин.

я в одну из них влюблюсь.

Безотказная девушка Люба,

ты не прячь свои белые груди, свои мягкие спелые груди.

Ты раздвинь их своими руками, чтобы мне утонуть бы, как камень, чтобы мне утолить все печали.

139

Полюбил я последнее время убаюкиваюиций ритм;

вечер. серенький, серенький вечер. даже рифмы не все зажглись, вечер. серенький, серенький вечер. Мать явилась с гостем, с майором, а девчонка не спит и не спит. Ревматизм ей лижет суставы и кроватка скрипит и скрипит, полюбил я последнее время убаюкиваюицй ритм.

Алрель 1958 
Остосвинел язык

новозаветных книжиц.

Азы, азы.

Когда дойдем до ижиц?

Ког да откликнется аукнувшееся в начале?

Когда научимся сводить концы с концами?

Любимая русская река Москва, набей мне мускулами рукава, очисть мои легкне от слизи, верни мне зрение жизни,

Mосква-река!

70

\section{Г.Оболауеву}

Я тоже думал.

что это стихи,

чTO это

$\mathrm{xa}-\mathrm{xa}$

да хи-хи,

a это

не хи,

и не ха,

и не хо,

и мне не до смеха,

и не до стихов,

и весь ваш Фет - пустяки.

\section{5}

Олицетворённая

женская слабость,

точёная шейка,

нежнейшая грудь,

не женщина - умирающий лебедь;

она те6я

так

обведёт и объедет,

и так тебя, простофилю, обставит,

что ты не успеешь и глазом моргнуть.

3 февраля 1962 
...И счастье улыбнулось! Кто бы

поверил - итурман, подцелив хворобу.

из части убыл; чёрт возьми,

везёт же людям! Слава Богу,

что ноги уволок с войны!

С утра всплакнув, моя Тамара

слегла. Но к ужину она

уже с героем нового романа

жила, как мужняя жена;

и Пушкин, шляпа, разбираетесь ли Вы

в вопросах, так сказать, любви?

65

Всё выговаривается в стих:

жизнь выговаривается.

и страх

смерти,

и стыд.

и смех.

Жаль, что единым жив человек

хлебом;

и что единой жив

верой: не в храм, так в хлев.

118

Реальное яблочко изобразить,

Tak,

чтоб захотелось в руки взять его,

понюхать его,

поцеловать, укусить -

для этого вовсе необязательно

держать на блюдечке самый плод;

достаточно, идя со службы,

подумать о нём, и свернуть

в сад слов:

их смыслов

и их слухов. 
Чем болыше ты меня ипыняешь,

чем болыне

бъёuыb,

гем я становлюсь сильнее,

тем злее.

Я научился переходить

гремящую ходынку в часы пик

под носом у засвиставішихся милиционеров,

Я выдрессировал на улице нервы

такие,

что, врё̈lь, не оступлюсь,

не грохнусь вниз головой под топот

голпы,

a, захочу, так сам остановлюсь,

cam

встану

на пути

notoka.

1946

309

Я теперь стал регулярно бри'ться,

меняю носки

и носовые платки.

Это за гранищей самоубийства,

а от нас какой-нибудь час

до Москвы.

Ночью падал снег

чернее копоти.

Шёл и ишёл до самого утра́.

Плотники потрогали -

а он ещё тёпленький.

Плотники на это мастера.

$\rightarrow$

26 мapta 1964 
Hawa берёт!

Германии

нет и не надо.

Огонь

жрёт

здания.

Розенберг,

Ширемберг,

Крейцбург -

чёрт разберёт.

С грохотом падает свод.

Взвивается знамя.

Orororo!

Город горит.

Город орёт.

Взвооод,

слушай мою команду:

Одер за нами.

Взвод, вперёд!

Взвод на запад!

Взвод, наша берёт!

4

Ты стал сатира и умора. живёшь, и радуешься тому, что можно жизнь прожить без горя и не молиться никому.

А сколько горя есть на свете! От скарлатины умирают дети.

Старуха моет унитаз.

Войну зовёт противогаз. ВОЙНУ ЗОВЁТ ПРОТИВОГАЗ.

1939, Днепронетровск 


\section{Андрећ Платонов}

Даже ночью светились цветы.

Мужик с жёлтыми глазами, прибежавший откуда-то из полевой страны.

Как заочно живущий, наравне с забвенной травой,сон ведь тоже вроде зарплаты считается, а люди нынче до́роги, наравне с матерьялом.

Останови́те этот звук!

Дайте мне ответить на него!

Возчик, смазчик, желтоглазый мужик, видишь, как теперь всё стало ничто?

10 февраля 1968

49

По-чешски „жизнь“ - жажда.

Жажда 6 ыт т

так же естественна,

как, скажем, „пить“.

Пей, только без дешёвых афоризмов;

ведь, если на то пошло́,

так даже „спать" -

это тоже жажда - жажда вспять,

в смерть;

а ты говорил - поговорим о жизни.

Надо исходить из жизни, Взять пример:

жил и умер; чехи говорят „земжел“.

Взял, допустим, и земжел;

и фйг с ним. 
Бессмыслица, двусмыслица, считалка, начну сначала, чтобы зациипало в горле как от ангины, загану загадку, которую разгадывать не надо, которую нельзя не угадать поэзию...

10 февраля 1969

365

Одеяло с пододеяльником

- Поскорей укрыться с головой.

Не будите меня - я маленький, я с работы, и едва живой.

Я свернусь калачиком

на краеiuке

у гремяцей, как тоска, реки.

Старики, откуда вы всё знаете?

Что вы знаете. старики?

12 июня 1965

680

Юность

убедительна.

Старость

непростительна.

Bcë вкривь и в кровь, и посему надо быть готовым ко всему.

3 мюня 1970, Днепропетровск 
Мирной жизни радуюсь вдвойне, сравнивая, то ли дело на войне.

На войне бывало забежиныь в санбат погреться скинеіи веlцмеllок, отпустишіь ремеllок, понемногу

ослабнет мынца сердиа,славно в медсанбатс. Tихо, хороіlio,

уходить неохота, да и сил нет;

и сидиніьь, и прислушиваешьься в тишия. как

свистит керосиновая лампа:

с вистнет, и стихнег;

Kak

идут

часы.

808

Утром солнце как шарахнет по верхотурам аж затрясёшься: вот это, брат, малевич!

12 октября 1973

809

Paccka3:

- Анна Войцык - никто никогда не сказал бы кахой она нация.

Если бы только не наші молоткастый, не нашІ, понимаешь, серпастый...

15 октября 197.3 
Люблю стихи Бориса Слуцконо толковые суждения

Ірямо1 'о харьковского хлопиа, как говорит Овсей;

веские доказательства недоказуемого.

22 октября 1973

811

... знакомая фамилия... ГІоляни... физическая химия...

22 октября 1973

324

Архангелы-евреи, говорит Сапгир.

Архангел Гавриил.

Архангел Даниил.

Tonop 33 поясом

и крылья на весу.

С архангельской лонцадью

в архангельском лесу

архангел Иосиф Бродский.

А Бог на иконе,

Бог в законе.

Бог, кақ осина, завяз в тумане.

руками сучит и ногами,

Бог в загоне,

а показания дают сексоты,

а председательствует сука,

и это - Суд над Тунеядцем Бродским,

где верой-чибирячкой был поэт Прокофьев. 
... что не в Стравинских, не в Кандинских, а в нас самих

космический эффект несоответствия;

да, птакова жизнь".

29 марта 1971

710

Стою перед дверью,

стучу, кричу на всю лестничную клетку

- Овсей!-

Он был старше меня на пятилетку.

30 мapra 1971

648

Ёлки-палки, считалки-заменки, кто последний за манкой-перловкой?

За манкой-перловкой отсель недалече, ты первый, я первый до белого корня...

20 ноября 1969

641

Меньше всего я хочу загадывать загадки.

Но я хочу говорить

To,

что я хочу говорить:

oxánы вать пóxма.

обти́сывать гри́мсы, двумерный, а то и бдно.

как признак отзовизма.

30 октября 1969 
Гришка Беркович... и Зёзька Беркович...

Гришка учился со мной, а Зёзька был младшче.

Оба похожи на зайщев.

Я, вроде бы, видел

Грицику - в последний раз - на каком-то плацдарме.

Зёзька тоже воевал, но мало:

он был в плену.

в фаниистском плену.

Как он выжил,

как он остался в живых -

непостижимо уму!

Точно одно:

Зёзька Беркович, типично-еврейский

зайчик,

вернулся,

шагнул на отцовский порог

(отец умер до революции),

чтобы,

отбыв положенный срок,

поселиться

навечно

в Норильске.

21 января 1969

\section{1}

Я Мойша 3 Бердичева.

Я Мбйзбер.

А. может быть, Райзман.

Гинцбург, может быть.

Я плюнул в лицо

оккупантским гадинам.

Меня закопали в глину заживо.

Я Вайнберг.

Я Вайнберг из Пятихатки.

Я Вайнберг.

За что меня расстреляли?

Я жид пархатый дерьмом напхатый.

Мне памятник стоит в Роттердаме. 
Один ревизионист написал на стене уборной:

„Товарищ, сделай два шага вперёд,

три назад".

И теперь согласно данным хунвэйбинских дацзыбао

по его вине

пол-КНР в говне.

25 января 1970

\section{Эпитафия}

Я,

всё-таки,

выне среднего.

Bыше

Хрущёва и Б

Я жив ещё, к вашему сведению.

Пишите мне:

Кремль.

до востребования.

15 декабря 1968

638

Одна баба сказала: А - Б.

Алёнка Басилова.

сексуально пассивная,

социально опасная,

хотелось бы с ней поеднаться.

Снится сон: мы грызём огурцы с Алёною.

Я в них души не чаю,

а девчонка мне: чао, чао,

мол, старый еврей.

не стой над плюсной,

у меня на тебя Дрезна не струит.

II aвrycta 1969 
... заниили как футбольный мяч...

27 августа 1973, Днепропетровск

803

Вроде бы на днях - давным давно.

Узнаю дома́.

Не узнаю домов.

Мостовой - и той узнать нельзя.

Нет, не менышее из двух зол- чужая зола.

А конечная остановка -

І1ятиконечная звезда,-

Хоть мон одногодки -

с'гарики в нодворотне -

ждут

от Бога здоровья...

.30 августа [1973], Днепропетровск

804

Оказывается, наша школа - икола имени Ильнча с'гоит себе, как стояла, из красного киріича.

Гоняют под лестницей шайбу ребята из нашего класса

Сапожников, Люсин, Залыцман...

Должно быть я обознался.

II сентября / 1973/, Днепропетровск

753

$$
\text { P. ню. }
$$

На всё удивляются.

Нихого ничему не учат.

Ну, какие же они старички?

15 февраля 1972 


\section{4}

Интеллигентный человек

выписывает „Новый мир“ и „Иностранную Литературу“.

15 февраля 1972

755

Роди́лся на чужбине.

Женился на чужбине.

В 59 лет

выгнали на родину.

14 марта 1972

761

Улитка, улитка,

ховай свою душу,

не высовывай ро́жки,

держи язык за зубами...

5 мая 1972, Евпатория

762

Кровью блевал, кровь проливал,

выстроил Храм-на-Крови́,

лысиной

Солнце ловил...

7 мая / 1972 ], Евпатория

763

Сколько погибло цветов! - проснёшься - и нет их...

13 мая [1972], Eвпатормя 
Любовь...

Предаю по буквам: Эль, Ю, Бэ, О.

$$
16 \text { мая / } 1972 \text { /, Ялгіа }
$$

775

Стихотворение называется: выдумка, граничащая с клеветой.

Писатель Игорь Холин известный хулиган.

Пришёл к моим знакомым, всю спальню обоспал.

5 декабря 1972

776

\section{Из поэмы}

Вы при часиках, при сумочке высынаете на перрон, маросейские трясучки, не описываемые пером и до сей поры отсутствовавшие; я вас вывел в третьем действии. а не в нервом и втором В память Хармса и Введенского.

$$
6 \text { декабря } 1972
$$

573

\section{Пришвинсхое}

Мартовские недоделки, с одобрения апрсльского света и майских цветов, как, всё равно, зяблики в лесу,их нет, но я-то их помню, и всё только кажется. 
Здесь -

пчёлки, вечные труженицы,

козявки всякие,

гусеннцы.

Мы жили на улице Чехова.

Потом,

через год или два,

мы

взяли и переехали

туда.

где песок, и трава

28 нюля 1967

12

Дома всё в порядке.

Я уже

п о к у ш л, лежу, курю на кушетке.

KoT

у моего лица

умывается.

Скоро придёт отец с работы,

сядет за стол.

придвинет счёты.

Мама

что-то шьёт в соседней комнате.

Я лежу на кушетке,

спокойный,

вытянув ноги.

KoT

у моего лица

умывается.

1939, Днепропетровск 
Мама, мама,

когда мы будем дома?

Ког да мы увидим

наш дорогой плебейский двор

и услышим

соседей напиих разговор:

- Боже, мы так боялись,

мы так бежали,

а вы?

- А мы жили в Андижане,

а вы?

- А мы были в Сибири.

а вы?

- А нас убили.

Мама,

гак хочется уже быть дома, чтоб всё, что было, прошло, и чтоб всё было хороіюо.

1941

695

\section{Леночке Рок}

Как твоя фамилия?

Нежно деформирую тебя, Леночка, дурочка.

Роккк. Через три к.

7 ноября 1970

697

Нет, не смешно,

как сказал молодому Каверину

молодой ШКловский.

Kто́ это?

- А я кто такой?

$\rightarrow \quad 21$ ноября 1970 
Главное - это, что в чём-то она права́.

В чём-то, не важно в чём. В чём-то самом

важном, наисущественном.

В том, что она сама

вряд ли учитывает.

В существования пра́ва

на существование.

И в том, что она - сама -

не в состоянии.

В том, что она - семья.

Как-то всё не так.

$$
\text { KaK-To - Bcë - }
$$

съехало,

стало врозь,

вКривь и вКОсь

с мест:

рельсы-с рельс.

Колёса - с колёс.

302

Вот уже

В шестьдесят четвёртом году

я иду

по снежной Остоженке.

Вот уже

в шестьдесят четвёртом году

я стою

у стоянки автобуса.

И чего я

raюcb?

И чего я

ждy

вот уже - в шестьдесят четвёртом году?

$\rightarrow \quad 2$ января 1964 
Похожа на Лёльку Шувалову.

Какая Лёлька Шувалова?

Лёльки Шуваловой можбыть уже на свете нет.

Лёльке Шуваловой сто лет в обед.

Старик, ты опять за своё? Опять шэтучки-дрючки?

У тебя-хвороба,

у дочки подружка,

сидят, разговаривают.

Вылумал: Лёлька Шувалова, Лёлька Шувалова.

8 января 1969

48

У меня-отличное здоровье, никакого мальокровия, ничер'га, врут все врачи, желудок варнт как часы, вчера, в час дня, Bce

женпцины смотрели на меня.

659

Вот как - Плучек еврей!

И Плисецкая!

Но, конечно, бо́льший интерес

представляют те, кого здесь нет, чем те, кто есть.

5 мapra 1970 
»Стихи из неглавных слов«

\author{
Стихотворения 1941-1982 гr.,
}

не вошедшие в Избранное 1974 r. 
00056818

420. Umo \& suxy? Bury - Paì. Kax offrsubaer, 0, 80xe,

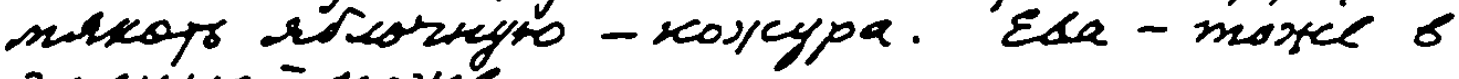

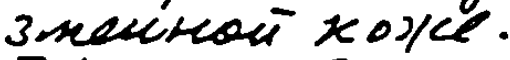

$Z$ kmo Tor? Kyxodka? Uли susurka? Hego pa-

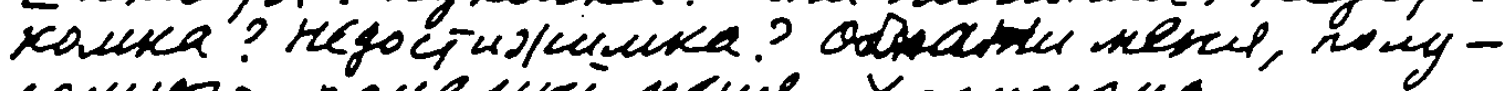
concozo, noyeryi neme, X ponscona.

1966

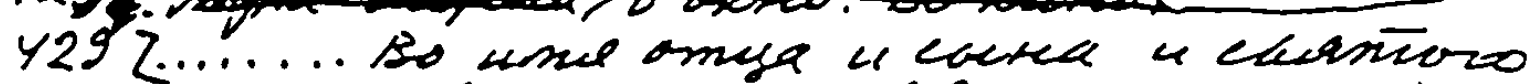

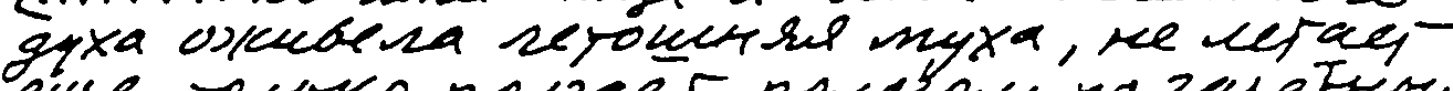
effe, pacosco nouscer nocos buy no zasefreme

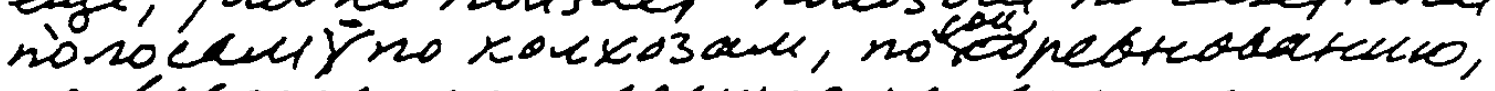
no becosuproncy cocyufecrasoraturso.

1966

425. Tepecibunacb - c bepdasa ra nusbriapb

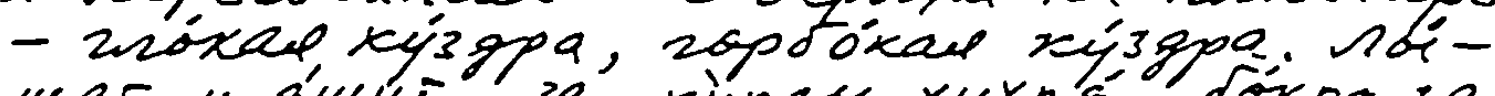

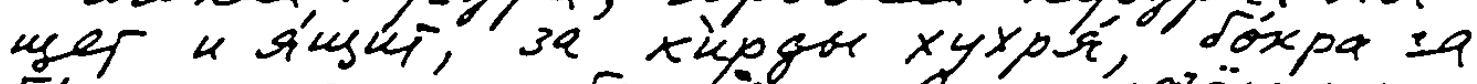
do'kpou, a jo u soxp ir. A noriagiepxou, ybepai noxpor, zxýxacor soxpor sanepor u zpor.

supuare: : noragbëрxom, ydèpoí noxp ò,

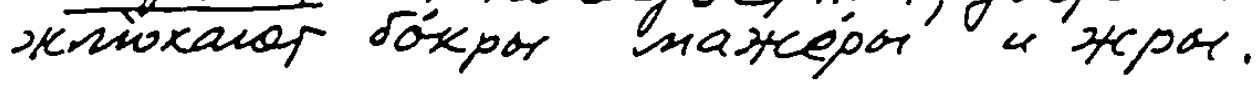

427. Ёкки - пиёжеки, пиёиюе фуёлки!!

1966

$Z$ sì, xax a-s-è, as-ei, nuss-eì, xak пиікнеі, как пиiкмег, $и$ bospugus: $2 y-2 a-g e \bar{u} !$

х) ороминесuras.

(2àra, $\left.22 \dot{a}^{x}\right)$

1966.

428.

Doul nog: noggàu. Cgygseu, e manag bëн, - ousivurum nunutalow, 4 c griears, $4 e$

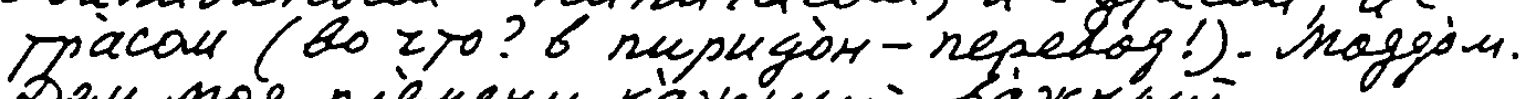

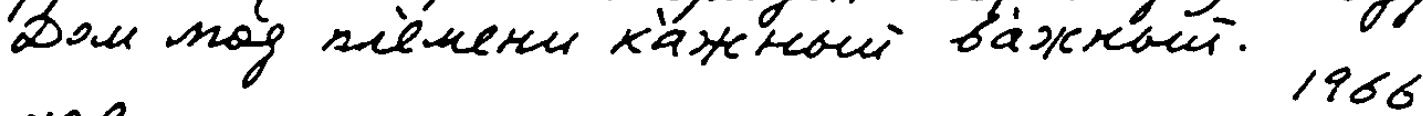
429.

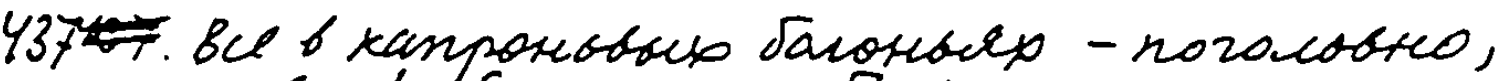

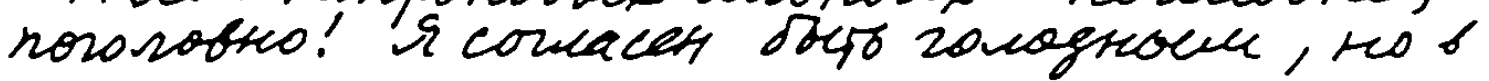

Из рукописи 1979 г.

Jan Satunovskij - 9783954795222

03:20:37AM 
Один сказал:

- Не больше и не меньше, как начался раздел Польши.

Второй

страстно захохотал,

а третий головою помотал.

Четвертый,

за, за, заккаясь, преподнёс:

- Раздел. Красотку. И в постель унёс.

Так мы учились говорить о смерти.

1940

13

У нас был примус.

Бывало, только вспомницы - он шумит.

TaM

мама возится с кастрюлями

и в спешке крышіками гремит,

и разговаривает сама с собой

о дороговизне и о себе самой.

У нас был примус.

У нас был примус, чайник, кран.

У нас был свет.

Teneps у нас ничего нет.

Вы эвакуированные.

1941

15

Кто там? Aх, это ты, заходи, заходи!

Заходи, снимай пальто, у нас тепло, у нас сегодня рай - светло, и чай заваривается, - садись, пей чай.

1945-1947? 
Отвяжись, не вой, на, вот моя жизнь, возьми её. война.

Спасибо за довольствие

и за иредоставленное удовольствие

повндать родных, покомандывать людьми, Іорассуждать

о мужестве

о любви.

Проццайте, кадровые командиры.

мы вместе в столовую ходили, обсуждали, кто такой герой, а зав кормил нас игогой.

Прощайте, фельдшерицы и офнциантки, драчливые, ках обезьянки, ох и неохота подыхать, пожить бы ещё, подышать. Хотя бы всюду уже, что ли, советская настала власть, чтобы люди стали меньше слёз натрасно проливать.

\section{Лето 1942, Запасноі полк}

Как я их всех люблю

(и всех убьют).

Bcex -

командиров рот:

"Pó-тá, вперёд, за Рó-о..."

(одеревенеет рот).

Этих. В земле.

„Слышь, Ванька, живой?"

\section{"Замлел."}

Bсе мы смертники.

„3а мной, жнвей, е́!"

Bcem

артіодеотовка в 6 , смерть в 7. 
У сердечников дурная память, что не надо, вспоминаешь.

Снег, да снег, да пó chery воробушки, байковые, точь в точь баушкины варежки.

Воробушки -варежки, да снег, да ночь, баюшки, да ох, не вернтся: хочешь вспомннть детство, вспомнишь: БЕГСТВО!

Стой, ни с места!

Месяц пахнет местью, смертью пахнет.

Хочешь вспомнить детство, вдруг, как ахнет: сердце!

Ох и пополито нашей кровушки, пополито...

На снегах смоленских навзничь, смертью...

Я уеду, как приехал, тихий, строгий, неспокойный.

Мама спросит через месяц:

- Он уехал, твой знахомый?

Maмa, он уже давным-давно уехал, и не пишет писем.

Говорят ещё, что немцы хаждый день бомбят Камышкн.

Осень 1942, Дy6овка 
Ox, и пополито нашей кровушки, пополито...

На снегах смоленских

навзничь,

смертью...

1942

29

Писем нету (и не будет). Поздно.

(На стене - без рассуждений - без пяти;

врут наверно); боже, почему так долго- полдень?

(окна, ласточки); пойти пройтись;

пусть мне кто ннбудь тебя напомнит.

Весна 1945, Кладно

30

Я. Hoвaxy

Хочу в город.

TaM

окна и стены.

Там женцины в буднячных платьях,

как будто на сцене:

в скрещенин лестниц;

в подъезде;

в огнях и в звонках перекрестий -

ках будто на сцене.

Там женщины

в будничных платьях

жгут письма,

Ждут Сводок,

и плачут, кақ будто на сцене.

Хочу в город. 
Брату и Марху Пратусевичу

Приезжаем в Харьков.

Слезаем с машины.

Возле памятника Шевченко

смех и слёзы жизни.

Масса вольных женщин

гуляет по саду,

подсаживается на скамейку,

заводит беседу:

один просвет, два просвета.

Скажите, а неужели

Bcex

евреев убили?

0 , мы уже и забыли

когда они были.

Масса, масса вольных женщин

любуется нами,

как будто "за боевые

никог да не видали.

32

Ходит слесарь по ремонту, заходнт в наш барак.

Лелька Фирсова, подруга жизни, огневая голова!

Измята

рябенькая блузка,

измена в волосах,

слюдянистые

глаза-стрекозы

взлетают - не взлетят.

Плачут, плачут все девчонки, слесарь слезы льёт.

Прополаскивает кровью сердце распроклятая любовь. 
Начало я проспал.

Рёв, вогли, взрывы матерцины.

По улице, задрав столы, оглобли, выварки, узлы (тыль!!) -

в затылок движутся автомашины.

Девятый час.

Дивизия снялась.

Связисты сматывают связь.

Прощай же, Штрелен.

где я „стоял“ и „был обстрелян“, где я двое суток протосковал, а на третьи землячку отыскал,

прощай, привал.

Дивизия снялась, связисты сматывают связь.

1944

47

Четыре года земля качалась В войне; Всё кончилось;

и всё сначала:

$\mathrm{ABB \Gamma}$;

БВГД:

на столько-то миллионов

меньше

мужчин;

зато как-будто больше женщин;

и есть друзья;

и есть враги;

и есть на свете дураки.

$\rightarrow$ 
В подлом, бессовестном бою:

- Сдаёшься? - не сдаюсь!

- сдаёшься? - не сдаюсь! -

Не охнув,

со дна встаю.

А, так не сдаёшься? Так -

тák? Со дна встаёшь? С одра -

встаёшь?

И хрясь, и два,

не в хрящ, так в грязь.

Оглохнув, со дна встаю.

- Пб́ уху его, в висок, под вздох;

под вздбшинкку. Ну, что, готов?

Испёкся?

Со дна встаю.

Сдаёшься? Не сдаюсь.

Сдаёшься? Не сдаюсь.

Задохшись,

со дна встаю.

Солдат. В строю.

81

Наверное, оттого, что нет у меня семьи, и нет земли, которую бы я назвал своею, все люди, и все зверн на земле весь мир стал мне семьёю.

Не думали ли вы хогда нибудь о том, что значит Дом?

Я думал об этом в старом венском парке, где женшины котировались на марки и шиллинги, а Осень, в виде дистрофических старух, подкрадывалась $\mathrm{x}$ сердцу моему... 
Налево от меня - сам Гныч.

Налраво - породистая фрау.

Мари и Аннамари - за винами, визави.

Гныч что-то доказывает, а я - яволь, я, я.

Я - пью и не пьянею.

Из гула - я - выуживаю полузнакомые слова:

шмекен - это кушать,

тринкен - выпивать.

Становится всё шумнее.

Уже у фрау Гныч раздваиваются глаза.

То придвигая бюст, то отодвигая,

она мне говорит, что, собственно говоря, ей этот старый хрыч...

И тут я замечаю, что я замечательно

понимаю по-немецки.

Бравый Гныч, захлебываясь, провозглашает спич

В честь многоуважаемого русского солдата.

Мари поднимает розовый стакан

и, поднеся $\mathrm{K}$ губам, пьёт,

и закусывает булочкой и салатом.

46

Как я живу?

Жнву наяву.

Давным-давно

было мне тяхело.

А сейчас всё равно.

Всё равно, ничего. 
Жить! - Не для стариков.

Им всё равно: a! скоро в гроб

самим.

И не потому, что СТРАШНО

помирать:

а жить, что, слаще?

Но как вы узна́ете, когда я умру, всё, что я думаю, и никому не говорю, никому?

И что и не думаю, а в себе имею?

„В давно прошедшие времена, ког да ещё на свете не было меня, когда, как в морге иодоформом, воздух пах юдофобством, В это время в Екатерннославе жил еврей. Еврей, еврею, под евреем, на еврее..."

Сашка Попов, перед самой войной окончивший Госуниверситет и как раз 22 июня зарегистрировавшийся с Люсей Лалидус о ком же еще мне вспоминать, как не о тебе? Стою ли я - возле нашего общежития представляю то, прежнее время. В парк захожу - сколько раз мы бывали с тобой на Днепре!

Еду на Чечелевку и вижу -

в толпе обреченных евреев об руху с Люськой - -

ты, русскии! -

идешь на расстрел.

Сашка Попов... 
Всегда со мной беда, всегда.

Куда бы я нк шел, туда

она войным-война;

сверну налево, а беда

за мной. Тогда круго́м бего́м

направо. А беда - „куда?“

Бедой ведбм, бегу.

89

Как у нас в соцгороде

с Карла Маркса и до Гоголевской

ходят

девушки, девушки, девушки,

в лёгких туфельках,

в кофтах,

в кудерьках.

Я бы

с каждой из них

нашёл общий язык.

$\rightarrow$

А у вас - кока-кола

и ку-клукс-клан,

а у вас комсомол,

а у вас кислый квас,

а у вас астронавты,

а у нас космонавты,

а у вас культ личности,

а у вас суд Линча,

а У нас кино:

куба си, янки нбоо!

$\rightarrow \quad 7$ сентября 1954 
Bo всех анкетах

на первой странице

Bompoc:

бывали ли вы за границей?

Ответ:

Я не был за границей.

Я был

в Ной Лимбурге, Фрейбурге,

Винер-Нейштадте,

проездом в Дрездене и, кстати,

где то в Румыния, забыл.

Ной Лимбург - отличное село в Силезин.

Ни единого фрица,

ни фрау,

ни киндера.

Черепица

осыпалась.

А кирха и вовсе без верха -

снесло.

Я жил в магазине „Рудольф Шток“, ход с главной улицы, через витрины, за кассой.

Уж-жасно негостеприимный Хозяин

все двери замкнул

и утёк

$$
\text { на Запад. }
$$

Но я-то ведь прибыл не в гости.

Я занял стойку,

убрал весы,

снял Гитлера

и перевёл часы

на час вперёд: по московски. 
Однажды ко мне пристала корова.

Я был тогда прикомандирован

К дивизия. Рано утром, тишком, нишком, добираюсь до передового пункта и слышу:

Кто-то за мной идёт

и дышит, как больной:

оборачиваюсь - корова;

рябая, двурогая; особых примет - нет.

Mañ 1946

104

Ночной фналкой тянет с луга

Спят

в мирном пламени зарниц

холхозных изб темносиреневые срубы.

В избе-читальне два окна зажглись.

Да,

вот такие краски,

вот такие

крыши,

тахой

край неба,

что как гладью вышит,

и холм вдали,

и реденькне деревца -

такими самыми

мы себе и представляли

TaM,

на каких-нибудь

подступах к Бреслау,

ког да закат нам кровью обливал сердца.

$\rightarrow$ 
Потянуло апрелем, землей, водой.

Солнце светит и греет, тепло, и светло,

и на щёчках у моей девочки

показался цвет

первой свежести.

105

Не оттого ли нынче день хорош, что светлым кроном листья тронул дождь. что воздух свеж, что пыль прибита, что в поле жеребёнок, ошалев от полной воли, вскачь пошёл, и вверx метнул два спаренных копыта, что песню прадедов напарник мой, нацмен, запел, что мне понятен смысл без перевода, что поспевает рожь, за ней пойдёт ячмень, затем овёс, не оттого ли

день хорош, что спорится работа! 


\section{На смерть Фадеева}

Обложнвшись подушками, свой неудобный, свой добрый наган, тот, с насечкой от Губельмана... -

значит, ты его помнил, должно быть, чистил, смазывал;

значит, ты не совсем ещё, парень;

а я-то, а я полагал -

всё истыкано ржавчиной,

всё насквозь проржавело;

давно ведь

дело было: Пожар Революции!

Пламенный бой

за Коммуну! -

Остывший, седой, тигроватый,

ты плывёшь - на Целинные земли;

а над тобой

проплывает продукщия фабрики Гигровата.

1956

108

Толкнула меня грудью,

и прошла.

Ох, да и не толкнула ведь, а только

глянула;

бровью не повела;

лебедью проследовала мимо столика;

зовы с поволоками отвела.

Нравится, ох, нравится

русская - как бы - красавица. 
Кто скажет, где, когда, давно, или недавно, тот берег,

и та вода,

что пела мне: „пан мой, Ян мой“ -

теперь их - даже во сне -

и то - не покажут мне.

Но можно - среди бела дня, волне попутной вверясь, увидеть, как ты бледна,

и как ты

мягко стелишь...

115

Хорошенькая официанточка,

смеясь,

каблучками стуча,

на завтрах

без всяких карточек

нам вынесла

cyn

и чай.

Насупывшись, но не отчаявшись, мы вышлк.

На дворе привязывалась гаубица

Но город- ещё не горел.

Он был ещё

K этому времни

Becb

B окнax,

Becb

В хрышах домов,

Becb

В полном умиротворения,

что длительным счастьем дано. 
Человек, которого я обидел,

был убит на фронте в рот навылет.

Не взвалили, не выволокли с поля, растворился в калужской земле осколок.

Я живучий. Я пережил войну. Я живой.

Я живу с женой. Я живу.

Что он помнит, этот человек, обо мне?

Что он смотрит из-под козырька бровей?

126

Tаких, как ты, на свете много:

худых, скуластых, легконогих.

Вот - обернулась.

Из под удивленных

бровей -

я्रко-синнй сверк.

Плечо, вскинутое вверх.

И сосок как у лимона.

127

Румяная, рослая, русая, она расшалилась за столиком:

- Нет, я себя толстой не чувствую, а чувствую тоненькой-тоненькой!

От ветра, должно быть, опухшие, я поднял с трудом свои веки

и понял -

как мало, в сущности, мы знаем о человеке!

Должно быть, от лени заросшие, как у легендарного Вия...

В то утро, моя хорошая, я видел тебя впервые. 
Битых

20 лет подряд

по этим коридорам,

преклоняясь, открещиваясь

$$
\begin{aligned}
& \text { и гугня́ } \\
& \text { на ходу - }
\end{aligned}
$$

о скорости разложения

окислов углерода -

бегал

взад-вперёд

профессор активированного угля,

а вчера

шёл летний дождик

с громом, брызгался,

пускал пузыри по мостовой, и сверкали

пятки

босоногих пацанов

перед медленно плывущим гробом.

Maй 1957

Памяти Б.А.Васьковского - зам. директора института в Электростали, где я работал после войны (до пенсии).

141

Ox, какой мужик прездоровый, рост-то, рост сорокавосьмивершковый; грудь распахнута по-флотски, а в зубах глазок папироски.

Он стонт ках дуб посередь дороги, выпростав навыпуск волосья; девки так перед ним и елозят, во какой мужик прездоровый 
Волны вальса, шопот, шорох южных Хвой всё слилось;

осталось только соль;

только берег, берег, опалённый добела, где хлебнул я полной мерой горя с морем пополам.

Июоль 1968

145

Секс-бомба Мэри, высший класс, по-голливудски - „вырви глаз“, феноменально! экстра-люкс!

Схожу в кино -

$$
\text { и - застрелюсь!.. }
$$

... От наших девушек, вплоть до девчонок, смекнувших, что $\mathrm{x}$ чему и для чего, от наших простеньких и скромных джиокондок, спасибо тебе, итальянское кино!

6 моля 1958

152

Люди приготовились к зиме, напилили, накололи дров.

Люди тянутся $\mathrm{K}$ теплу, $\mathrm{K}$ семье.

ТЫ ОДин ни бэ ни мэ, шапку в зубы, и будь здоров,

ты один, и я одна, муж и жена...

$\rightarrow \quad$ Сентября 1958 
На старости лет

расхотелось

слоняться

вдоль книжных полок,

и, вынырнув на свет в переулок, Mы

щуримся на незнакомок,

а осень

а поздняя осень

посвечивает из за ветвей

рассеянно и ще дроточь-в-точь как ранней весной

Aпрель 1958

153

На пыльных улицах, устав от дум, которые наш мозг переутомили, вдруг встретить брызжущий сквозь шум и дым фонтан, как в Крымской области на Укранне,

h,

тpeneщa

(нет, весь я не умру!)

взвесь капелек

пить

бронхами сухими, пить впопыхах, взахлёб,

без рук,

без губ;

фонтан - лекарство

от гилертонии

и стенокардии. 
Противна мне твоя Америка,

мой славный малый, Джонни, Джонни;

a, помню, я махал ей с берега,

мол, браво, Джонни, здравствуй Джонни.

Американцы, немцы, русские...

Так выпьем с горя, выпьем, что ли, закусим по такому случаю

московским чёрным хлебом с солью.

Американцы тоже русые и рослые, как наши парни.

Так выпьем, зачехлив орудия.

в честь встречи двух союзных армий.

Америка махала с берега два берега у Эльбы, Джонни;

и я не знал, не знал, Америка,

что значит брат мой - враГ мой, Джонни.

Я не был на „встрече" с частями американской армии, помню, мне о ней рассказывал друг мой Ян Новак, сослуживец по армейской газете.

17 сентября 1974

155

Часто ли я изменяю жене, или не часто, но всякий раз это луч света в тёмном царстве.

Явилась - светятся все жилки.

В слезах: зажмурься и прижмись!

Свежинка моя, живинка, Свяжись со мной на всю жизнь!

Несчастье ты несёшь мне, или счастье, но всякий раз это луч света в тёмном царстве.

ABryct 1958 
Я живу на старом месте

и, как встарь, бодрюсь и хорохорюсь, лишь порой - ножом по сердщу -

ну, а если, слышишь, а если; чья тогда возьмёт-переборит сила боли

или

слабость воли?

28 ноября 1958

164

Мхи и пальмы, рыбы и звери

самой звездной из феерий,

распустивши хвосты павлиньи, стёкла доверху заслюдя, жадным взорам мокм явились фосфорические джунгли льда, плюс и минус, север и юг, Африка и Полярный круг.

$1958 ?$

166

Я не хочу воевать

и никог да и нигде

я не смогу убивать

грязных вонючих людей,

жалких - коленки дрожат,

слезы стекают со щёк,

страшных, с кинжалом в зубах

братьев моих и сестёр

я не могу убивать.

$\rightarrow \quad 6$ января 1959 
Спросите их, спросите инвалидов, тех, для кого навеки кончилась война, как долог мирный день, Как ночь длинна, и как является в проемах туч, в разрывах пикирующая луна.

Вы бродите по берегу; солнце уже зашло, но небо не померкло и море - светлым светло. Я знаю - наука не может схватить и выявить связь свечения неба и моря с свеченьем Ваших глаз. Всесильные логарифмы на сей раз, увы, слабы: не вымерить и не выверить длину волны любви.

5 января 1959

169

Город играет на гитаре.

Прекрасно.

Как, это женщины? У, твари. Пикассо.

И дело не в том, что с годами

в клише

слились

в навидавшейся видов душе

витражи

Леже и Брака,

а в том, что они ког да-то

мне жадную черень глаз обожгли

и в кровь, как железо и кальций, вошти.

12 января 1959 и 28 июля 1974 
Не умею по-тарабарски

тары-бары растабарывать.

Чешский, польский, сербохорватский

словари мои, словарики,

вы стоите кладкой тесной,

с вами мне легко и родственно.

A 4то "пасека" -

по чешски "просека" -

это даже интересно.

4 января 1959

173

Не спит, до поздней ночи

прислушивается мать.

Являться стала дочка

в час, в два, а то и в пять.

Из-под длинной чёлки

сияют льдинки глаз.

А стыд? А чувство долга?

Всё это - чушь

и-блажь!

10 января 1959

177

Прости Господи, и распроэтакая красота пропадает! Просто даром, дуриком, без рассудка; правду молвить простота хуже воровства;

да хоть за жулика, за пьянчужку - лучше бы...

И который год

убивается не наубивается;

грудью мается;

а ткни в титьку - потекёт...

1 декабря 1959 
Ни кустов, ни травы, полон двор детворы, тут и Хаям, и Срулик, тут и Темников Шурик, мое детство и юность, тут и Карп Соловейчик, тут и Бенчик-Шменчик, дальше мал мала меньше.

12 мая 1959

179

Осень-то, ёхсина мать, как говаривал Ваня Батищев, младший сержант, родом из глухомани сибирской,

павший в бою за свободу Чехословакии.

Осень то, ю́-маю́, все деревья в жёлтой иллюминации.

1959

181

На войне как на войне, и тае́, и не таé, плащпалатка хорошая вещь, но от смерти защиты нет. Нет, от смерти защиты нет.

Что $ж$, солдат, на то война, пей до дна, пей до дна, и, накннув брезе́нтовый плащ, стой как штык за советскую власть. 
182

Снег с утра

сине́е неба,

всё вокруг

синё от снега.

В жёлтых окнах

дом напротив.

Тени, тени

в жёлтых окнах.

Свежесть зимняя, грозя им, светит

синими глазами.

17 сентября 1974

Начало этого стишка я вставил потом в детскую песенку, напечатанную в моей книжке "У медведя во бору“" (кзд. Ф и С, М., 1974)

183

И дело не в том,

что с годами - в клише слились -

В навидавшейся видов душе

витражи Леже и Брака,

а в том, что они ког да-то

мне жадную черень глаз обожгли

и в кровь, как железо и кальций, вошли.

И как от угля, в темноте горящего, мне глаз не отвести никак

от этого на первый взгляд невзрачного, от зряшного, на первый взгляд, цветка.

II января 1959

Мальчики,

не поддавайтесь девочкам,

с ними толковать буквально не о чем,

это существа из антимира,

наше сосуществованье с ними -

мнимо.

$\rightarrow$ 
Неправда, она не меняется:

на старости лет, как и встарь,

волнуется и влюбляется душа,

которая - пар, которую Пушкин выдумал! -

зато уж - вынь да положь -

её не пугает ни Библия,

ни финский, тем более, нож.

Единою мерой меряю, как в молодости, так и теперь, душевное доверие;

иных не надобно вер!

1960

186

Oтстал

в пути,

устал, мне не дойти;

на плечи снег напа́дал,

ни охнуть, ни вздохнуть;

ни засветить лампаду,

ни этот

сон

стряхнуть.

1 декабря 1959

190

Ленин был великий, Сталин дорогой, а теперь Никита,

да здравствует, долой.

Господи, помилуй мёртвых и живых, мы едем на "победе",

Америка, держись.

Подайте копеечку Иван-царевичу.

$$
17 \text { сентября } 1974
$$

Иван-царевич был наш злектростальский нищий. Я спрятался за него тогда. 
Случилось непонятное:

посередине апреля

весна

пошла

напопятную,

оставив поле сражения.

Едва

объявили по радио

об этих передрягах,

как в город

ворвались

каратели

в башлыках

и nanaxax.

Со свистом,

во всю ивановскую

рванулись врассыпную.

всех встречных

нагайками

хлеща

и полосуя.

Но жители

нашего города

держали себя гордо:

хлещите,

стегайте, сволочи,

теперь вам уже недолго!

18 апреля 1962

212

Какой он ветреный, март, какой он

крученый-ве́рченый;

снег так и хлещет,

но $\mathrm{K}$ вечеру

ещё разведрится, факт!

$$
\rightarrow \quad 10 \text { марта }
$$


Казённые вещи - законные вещи:

бушлат, плащпалатка, шинель.

Мы в шапках-ушанках и в ватных фуфайках

бездельничаем целый день, садимся на снег, крутим козью ножку, пьём вязкий трофейный коньяк.

Мы двинем на поиск поздно ночью, закутавшись в маскхалат.

1960

205

Нашей улицей ветер овладел, наша улица

в ветре и воде,

и такая

студёная

весной вода,

и такая синева, и светлота,

что запомнится, знать, навсегда.

27 февраля 1961

207

Ax, как пахнет, как пахнет сирень!

Ну и пусть ее, знаешь, Бог с ней.

Ведь такое -

только затронешь

и опять заведёшься,

и вспомнишь

город,

вспомнишь Потёмкинский сад, как ты в дом наш - букет принесла мокрый,

в каплях,

Со звоном, со стоном...

Хватит!

Дальше - запретная зона.

6 мая 1961, Н.Кастрополь 
Я рядом с Ялтой, в Кастро́nоле.

Природа здесь великолепная.

Шум моря, и птичье щёлканье - Чивитта, Чивитта Веккья!

Здесь море сладко-солёное, то тёмное, то бледно-зелёное, утёсы и скалы рогатые с ног до головы окатывает.

Хожу, кипарисы трогаю, их хвоя мягкая, терпкая, и так мне здесь любо-здорово - Чивитта, Чнвитта Веккья! 18 мая 1961, Н. Кастрополь

209

Старый город немцы взорвали.

Пошатнулась, покатилась мостовая.

Я бежал по дымным развалинам.

Я бегу до сих пор не переставая, я бегу...

Тихо-тихо, понуря голову, прохожу я по новому городу.

Он и выше на этаж, и краше.

Не хочу его видеть даже, не могу...

21 мая 1961, Днепропетровск

227

Главный инженер.

Физиономия

а-ля Джек Лондон.

В стальных глазах

отразился чернильный прнбор.

Дюже импонирует

диплом

с апломбом

слабым женщинам на передок.

$\rightarrow \quad 13$ февраля 1962 
Мальчишкой я подхалтуривал

в области политической карикатуры.

Чемберлен, Бриан, Желтый Интернационал.

Бывало, не хуже Ефимова

Кромсал их до единого.

Kak бor черепаху.

уродовал врагов народа:

Бухарина, Радека, Сокольникова, Пятакова.

Халтурный художник,

поэт халтурный,

я не был бездарный,

Я был бездумный.

4 декабря 1961

217

До чего мне нравятся озорные девки, что прилюдно драются в речке возле церкви, так что поп

с молитвою

путает „едриттвою“.

До чего мне нравится здешняя природа,

и сыны, и дочери здешнего народа -

Монино,

Железнодорожная,

Перово.

6 сентября 1961

Перед глазами стена (с окнами, дело не в том; дело не в том, что - дом, и что соседи в нём, вёдра, помои, переберут, перемоют, мол, он, да она, муж, да жена - одна сатана; дело не в том. Стена). 
Борис Абрамович Слуцкий, товарищ эксполитрук, случился такой случай, что мне без Вас, как без рук (случился - такой - случай!)

Что мне не Фет, не Тютчев, не Бунин-Сологуб и не Случевский, a

Слуцкий, Ваш стих, раздражающий слух, понадобился вдруг.

Сознательное стихотворение, снаряженное как на войну, понадобится в наше время не мне одному.

5 декабря 1961

233

Чужая, чужая, чужая

пробралась обманом в мой сон, и мучит, и точит,

и жалит,

и жизнь мою

ставит вверх дном.

Бесстыдница, руки мне лижет, теперь присосалась к груди.

Уйди, я теперь ненавижу.

Куда же ты? Не уходи.

$\rightarrow \quad 26$ марта 1962 
Назыму Хикмету

щит

на вратах Царьграда

висел, а- зря.

Нам - этого - не надо,

ни града, ни царя.

Цари - вещали:

„Иду на вы“

Я Вам, товарищ,

скажу на ты.

Хикмет, мне дорог

твой - без особых рнфм -

сухой, как порох, революционный стих.

И есть театр Сатиры, -

спасибо за театр!

И, главное, спасибо,

что ты - „не дипломат!“

Не знаю, кто твой пращур -

Сим, Хам ли, Иафет, товарищ турок,

ты - правильный человек!

24 декабря 1961

Свонм потайным фонариком

иной раз всю ночь до рассвета,

знай, шаришь,

светя,

по словарикам,

nо закромам,

no сусекам.

- в котором-нибудь да отыщется-

то слово,

что правду скажет.

А сами стихн не пишутся.

Их пишут, как землю пашут. 
Пустые стоят коровники. о которых Есенину пелось. На лицах у колхозников молочно-восковая спелость.

А жить-то ведь каждому хочется, а не жмыхать газетное сено. Heт, не скоро, видать, ОКончится кровопольная эта система!

13 марта 1962

Приснилась мне обманцица, притворщица, изменщица, беременная женщина, а - девочка по внешности, В милиции заявленная, любовником отравленная. Бессильная, безвольная, ничейная, погибшая, приснилась мне любовь моя единственная бывшая.

26 марта 1962

Рассказать вам про случай из жизни, как недавно один человек день, другой не явился в цех и чего из этого вышло?

А сегодня выходной, проживем и без проходной, и без цеха, и без шпиндельного станка, и без ОТК, и без ВТЭКа.

Захочу - пропью 100 рублей в чайной. Захочу - схожу на хоккей с шайбой. 
Ни на русого, ни на чернявого не науськивай меня, не натравливай, и падучего бить, лежащего не научивай, не подначивай.

Я люблю

Шевченко

и Гоголя.

Жаль,

что оба они

юдофобы были.

10 января 1962

246

Гривенник уронишь - та́к обидно.

Шаришь, чертыхаясь, в три погибели.

Небольшие, вроде, деньги:

ну, подумаешь, пройдусь пешком.

А ведь тут не белую копейку совесть потерял, - и хоть бы что.

8 июня 1962

248

Женщина, сытая любовью

мужа

и друга дома,

и изменяющая тому и другому

с первым проходимцем: „ай лов ю“;

переимевшая

разных и всяких

по форме и по сути, -

чем заглушить ей

тревожный запах

сытости, смерти, скуки?

17 мюня 1962 
Если нет

ни ада,

ни рая,

так куда же

все умирают?

Соглашаюсь

на вечные муки,

не философ я,

и не сектант,

отрубите мне

ноги

и руки,

не хочу умирать навсег да!

12 сентября 1962

252

Я завидую Вам,

Окуджава,

Вы

„совсем ведь ещё молодой“,

и одышка

не страшна Вам,

и не нужен валидол,

и неважно, что, вот, не печатают,

(„золотистый, золотой“)

по ночам Вас читают девчата,

(не качайте головой,

Окуджава...)

16 сентября 1962

Если в стихотвореник отсутствует пафос, значит у поэта пониженный тонус.

А если у поэта пониженный тонус, это, безусловно, не плюс, а минус. 
Достану томик своего учителя.

Давно я Хлебникова не перечитывал, не поднимался на валы Саянские,

В слова славянские

не окунался.

Исполненная детской мудрости

струится речь, двоится, пристальная, расчесывая кудри водорослям,

людские судьбы перелистывая.

1962

\section{1}

Говорят,

и капли не пила.

Говорят, поллитра выпила.

Говорят,

с парнишкой поглыла, наградила, сука, триппером.

Говорят, на острове

кусты

дикой акации.

Ночью

светятся

истлевшие кресты.

Тихое кладбище.

Между этих

древних могил

свежая могила есть.

Говорят,

цыган утопил.

Говорят,

сама кинулась.

$\rightarrow \quad 6$ сентября 1963, Днепропетровск 
Затмись, светило, свети вполсилы"; болтун, разиня, не суйся в драку отрекут от Россин;

а меня, читаку, оплетут, околпачат, оглушат, проведут на мякине, на могильной глине.

26 мая 1963

\footnotetext{
'В более ранней редакции вместо третьей строки было:

„Вознесенский Анарюеша, треугольная груша, чудак, разиня

(примечание составителей книги: Я.С., Хочу ли я...)
}

Может быть,

в каком-нибудь Энске, может, в Гомеле, может, в Козельске

старый нищий

вроде меня

ходит,

ищет

„вчерашнего дня".

Может, где-то в селе сибирском

у распластанного плетня

Кто-то дальний

и Кто-то близкий

вспоминает кого-то - меня.

21 aвгуста 1963, Днепропетровск 
Здесь были поля полосаты, как талес.

Здесь

даже кладбищ не осталось.

Здесь

женщины

любят,

чтобы их разглядывали,

раздевали глазами.

Здесь женщины лгут:

- а мы вас згадувалы.

Згадувалы - значить, ждали.

Здесь я - часами - бродил по улицам, твердя как в бреду беспрестанно:

о хоть бы одна из них

обернулась

и мой приезд оправдала!

30 августа 1963, Днепропетровск

280

Далеко от Днепропетровска, на невзятых подступах к Москве между Фейгиной и Островской наша мама лежит в песке.

Мы ей мертвой

глаза закрыли, сколотили гроб

из досок, на веревках спустили, зарыли

В этот серый сырой песок, и поставили черный камень, черный камень, на глазу бельмо, и живем теперь сами, без мамы, курим, ленимся, пьём вино.

6 октября 1963 
Забываю, куда пошёл. забываю, зачем пришёл, жизнь -

была -

или не была.

забелило,

заволокло,

очереди за молоком,

очереди за хлебом,

прозеваю очередь за хлебом,

вспоминаю,

кого не следовало,

а кого любил,

Tex -

давно забыл.

$\rightarrow \quad 4$ декабря 1963

267

Красок нет.

Иссякли все запасы, источились кладовые, опустели

склады.

Ho

не прекращаю

запись

преходящих ощущений -

угольями из печи погасшей

набросаю тему;

буквами обозначу:

"умбра",

„киноварь“,

"краплак",

"сиена".

18 сентября 1963 
Я не против реализма в живописи.

Жизнь

важнее видимости.

Обманув

доверчивое зрение,

окуну

глаза

в пейзаж Марке,

поплыву

на акварельном поплавке

В три доступных взору измерения.

$\rightarrow \quad 15$ сентября 1963

273

Море - и небо.

Mope - и берег.

Море - и пена, всасывающаяся в песок.

Море - материя и энергия.

Морс - время.

Mope - всё и ничто.

Иди, умойся морем.

Mope моет.

Море успокоит.

Умри у моря.

3 октября 1963

278

Зинке Саввиной не дали бюллетень.

И Натаuпке Бариновой не дали бюллетень.

Вы 6 послушали, как они обсуживают

медицинское наше бесплатное обслуживание.

И начальник цеха тоже жмот, у него кормилок полон рот, у него график.

ну его на-фиг. 
Вышли трое

В костюмах правительственного покроя,

три сфинкса,

три дворника,

три кубышки,

опиджаченныс по вссм правилам портняжного кубизма,

с цитатами на устах

и с шляпами в руках!

18 ноября 1963

299

Хорошая баба:

высокая, рослая.

Смотрит строго, а, ничего, оборачивается.

И эта, криворотая фря с наглыми гляделками.

И та, и та. И эта, мамочка, восковая, вкрадчивая, мочеполовая.

Любуюсь женщинами.

Думаю о женщинах, доступных моим глазам.

24 декабря 1963

306

Живу в подмосковной

деревне.

Снимаю мызу

у деда Мазая.

Из города

ходит автобус.

B автобусе тряска.

В автобусе жарко.

В автобусе давка.

А красная девка

ликует:

„Жми туже, не будет хуже!"

Живу в подмосковной деревне:

Купавна.

23 марта 1964 
Признак, известный в медицине:

с приближением старости

мужчине хочется любить всех женцин,

а молодых - в особенности.

Каждый раз, когда, распалясь,

я нацелюсь на какую нибудь фифу, меня неукоснительно заносит вкось

с тротуара на мостовую.

Нарушается координация движений.

Нарушаются функции.

Признак, известный в медицине:

старость.

15 марта 1964

311

Вспомнил, на кого ты похожа.

В дождь, на сеновале.

Со слезами.

С синяками под глазами.

И со светляками -

в полутёмном,

полусветлом кинозале,

оживая каждый сеанс

на московском плоском экране

$\rightarrow \quad 29$ июля 1964

313

Eва, цивилизованная еврейка, любительница -

конкретной камерной музыки

и абстрактной живописи,

поэтесса из мебельного института,

только тебя нехватало в моей жизни, Ева, только тебя... 
Пора, пора писать без рассуждений.

с первого взгляда, на зелёной развилке, B poce,

пока не побило морозом.

Pe-жe!

Прибавить шаг!

Шире шаг!

Военный рожок.

Полевая почта.

Походная кухня.

Медсанбат.

Я, должно быть, слышал и видел это в кино.

\author{
Сквозные \\ проникающие \\ сукровицей \\ истекающие \\ в кузове \\ шинели \\ навалом \\ залубенели.
}

Я не ранен. Не лежу навзничь, в яме, промежду убитыми.

Я летатлин.

Лечу,

куда хочу,

крылышкуя

между сталактитами

и сталагмитами.

27 мюля 1964 
Я, ты, он,

Филька Иванов,

Иван Израялевич, на минуточку пьяный,

Велимир Хлебников,

Владимир Татлин,

и даже

Мэрилин Монро -

Bce

мы

умрем.

Только на днях

подморгнул было

солнышіку,

вывернувшемуся из-за туч, и уже -

дни проходят,

и лето проходит,

проходит розовоносая красавица, проходят

мальчинки.

Один мальчишка говорит:

nОт ритма и аритмия

родится антиритм.“

Другой говорит:

„В эту фройляйн

магнит, должно быть, встроен."

А третий и вовсе -

Иван Израилевич в перевернутую трубу.

Боялся одного,

а умер от другого.

II abrycta 1964

321

Думаю об Америке. Бойсь, Америка.

То-ли рок-н-ролл, то-ли твист,

то-ли руки вверх, то-ли вниз,

то-ли сволочь и фарисей,

то-ли свой в доску парень из ЮЭСЭЙ-

поди, разберись в Америке. 
Брючки

В дудочку,

жилетку

в клетку,

HOC

В чернильницу,

pot

на крючок, -

'

мой бледноликий,

и мой красновекий

брат -

Великий наоборот.

Вот он вылез из трамвая, чумчарара́,

у него в одной руке авоська,

а в другой записная книжка.

Лист...

точки...

больше ни строчки.

Еще ничего не исключено.

И уже - не ис-клю-че-но.

19 abrycta 1964

320

Требуются способные рабочие.

Рабочие,

способные управлять производством.

Bacя,

вот тормоз - жми,

есть газ - газуй.

Две пятерни, перелистывающие Пастернака.

Извилины, вибрирующие переосмыслить квантовую механику.

Два ока,

две глазных воронки, для которых масло-Матисс.

Повторяю: требуются подсобные рабочие.

5 сентября 1964 
Рассказать вам всё?

Не сказать ничего?

Были два партнёра, два монтёра,

в нашу Любку влюблены.

Стала Любка

тётей Любой,

слабой и беззубой, взрослые дочки

у матери-одиночки, космос,

климакс -

Bcë

слилось

воедино,

рассказать вам всё -

не сказать ничего.

22 oxтября 1964

333

... коричневые губы, коричневые веки, сквозь кисею блузки два Мазка сепии, из-за куска хлеба, три дня не ела, жить надоело, нет, ничего не было.

20 октября 1964

340

На носу декабрь. На дворе снежок.

под снежком ледок, как заметил Блок.

Вот и Блока нет, Пастернака нет, одиноко мне в ледяной стране. 
Это - я - и не я.

Это - он - и не он.

Не неон, не аргон, не криптон, не ксенон.

Это - эн-два-о, веселяцций газ, чёрный глаз анестезиолога в марлевой маске, всматривающегося, как сварщик, с высоты, в это - я - и не я, ты - и не ты, не он, не аргон, не криптон, не ксенон, не неон.

25 сентября 1964

\section{9}

Картина с таким сюжетом зевак не остановит.

Не всякий знаток, между прочим,

ее выражение уловит;

она не выходит - за раму -

в трагедию или драму;

но, если ты ранен в сердце,

Приди и Смирись со смертью.

1964

\section{7}

Тюмень, да тёща,

да Марьина Роща.

А не приелась ли вам солома,

та самая, что дома едома?

Не тянет ли вас поглядеть на девчонок

с косыми коленками из-под юбчонок

на стадионе

в Нанси и Лионе?

Не тянет? Хы! Так оставайтесь дома.

Дома и солома едома.

Тюмень, да тёща,

да Марьина Роща. 
Легкость в мыслях необыкновенная:

0. балда-с,

неужели это не про нас?

Неужели

не мы -

ручкой шмыг,

ножкой дрыг,

то за дочкой,

то за маменькой?

И под занавес, под занавес:

- Сульфидин-с!

Лабардан-с!

Браво бис,

о, балда-с!

3 января 1965

355

Она лежит на спинке - святая простота.

Как гладко на картинке яичко живота.

И рот слегка разомкнут, и розы лепестки - легки. и робко смотрят на публику соски.

1965

367

Я - пою́, ́⿱㇒日 - пою́, ́ - пою́, 3á-бывá-ю́ прокля́тую ста́рость свою́, про́ девчо́н-ку́, что то́лько что ми́мо прошла́,

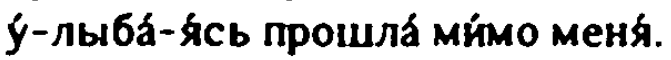

Эта уль́бкха - предназнача́лась - не для меня́, предназнача́-ла́сь для все́х, кро́ме меня́, эта уль́ббка - предназнача́лась - для всех, крб́ме меня́, кро́ме меня́, труляляля́! 
Нет никого на свете

желанней

этой дурнушки,

золушки нашей, Эльки.

Взял бы

и съел бы

изюминки-веснушки

с Элькиной шейки.

А где её дом?

А чем она пахнет?

За бродом.

Мёдом,

Элька-Конопелька.

Играйте,

жидовские дети!

На скрилке!

На флейте!

Еще не зажгли

для вас

освенцимские свечки.

1 мapra 1965

359

На колокольне завыл петух:

- гитлер - капут! гитлер - капут!

отче наш, иже еси на небесех, спишь? Не... Спи...

Были ли вы в Бухенвальде, или закопаны в ямы под Ковелем,

я вас не знаю,

я вас не помню на колокольне...

28 апреля 1965 
Отиепись от меня, отвяжись, венский жид, Зигмунд Фрейд. Бред не я. бред оно.

Решено, говоришь?

Bpëıu!

Я - не отцеубийца!

19 апреля 1965

361

Acb?

Вчерась

на реке карась

щуку хрясь.

Оборвался с дуги мужик, ажно селезня пот прошиб.

Нутка, тётка, ступай-ка по́ воду. надоть выпить по такому поводу.

26 апреля 1965

369

Побывал я в Польше

в минувшую войну;

шевелил уголь в топке;

кайловал целину;

повидал немало,

да не вы́ видал ничего.

Ну, и что?

Ну, и ничего.

18 мая 1965, Ялта 
Хожу, дышу морем, слушаю шум моря.

Он уже, должно быть, не тот, который слыншал Пушкин.

150 лет тому назад много это, или мало?

А 150 тысяч лет? А вчера?

Вечное, млечное море.

14 ман 1965, Ялта

Март меня не радует, апрелю не верю, мой месяц май месяц.

Эй, зелёные, пошевеливайтесь, колокола, тополиным звоном

заливайте города -

Новгород,

Звенигород.

Миргород,

Мирумиргород!

18 июня 1965

378

Это я, на мусорном ящике, босой, вычебучиваю чечётку.

Это я, о сухую траву отираю штык.

Это я, живу с чужой женой.

Это я, это не ты.

12 сентября 1965 
Брижитка! Бардотка!

Kapтouкa! Морковка!

Кубышка! Кадушка!

Малютка Брижит.

О, Брижит!

А, Брижит!

У, Брижит!

Э;, Брижит!

Где́ Брижит?

Bót Брижит.

Кто́ Брижит?

Я Брижит!

6 декабря 1965

398

Я - трус, трус, трус

(написать на листкс бумаги),

я - гнусный трус

(и забыть изорвать, забыть

утопить в унитазе).

23 ноября 1965

401

Второй месяц.

как мы схоронили „деда“.

И теперь я стал „дедом“.

- Дед, а, дед,

сходил бы за хлебом.

Дед? а, дед?

26 ноября 1965

403

В черно-белом городе, среди минеральных деревьев

я один - С живой природой над головой;

минеральных деревьев из несолёных солей.

25 охтября 1965 
Экспрессионизм-сионизм.

Импрессионизм-сионизм.

Но и в РЕАЛИЗМЕ, при желании.

обнаружат сговор с ИЗРАИЛЕМ.

20 декабря 1965

413

Было,

и осталось,

и забыть не могу.

как я шёл со станции

в крови и в снегу.

Шла навстречу

девочка,

ребёнок лет пяти.

Смахнула меня веничком

с своего пути.

I февраля 1966

418

Время

перетасовало

даты рождения и смерти.

Плечи, глаза, ладони и брови

время

перетасовало.

Время оставило

- на время -

карточку,

на которой - стёрты

даты-рождения и смерти. 
Из цикла "Старая живопись"

Что я вижу? Вижу - Рай.

Как обтягивает, о, Боже, мякоть яблочную-кожура.

Eва -

тоже

В змеиной коже.

Кто ты?

Куколка?

Или личинка?

Недотыкомка?

Недостижимка?

Обмани меня, полусонного,

поцелуй меня, Хромосома.

6 апреля 1966

422

Вот мы сидим на крылечке, и слушаем

с детства знакомый рассказ:

„Жили-были старик со старухой“.

Так, оказывается, это про нас.

3 апреля 1966

\section{4}

Вроде Володи.

Вроде Сережи.

Вроде похоже.

Вроде похуже.

Вроде того.

Вроде сего.

Вроде всего, и всего ничего.

24 марта 1966 
Бейте поэта, бейте, гады, бейте;

втопчите его в кал - овечий, свинячий;

калечьте, увечьте;

поддайте ему, наконец, чтоб он не встал с подстилки;

добейте его, пожалейте;

я его знаю - это Оська Мандельштам.

8 апреля 1966

442

Отгремели, как говорится, марши.

Можно взять такси и махнуть хоть за Джанкой.

А если тебе охота - пиши себе вирши.

Кипарисы

в рваных глащах

стерегут наш покой.

Наберусь ли я

смелости

изобразить этот воздух,

именуемый

Гаспрой, Ливадией, Ласточкиным гнездом

или Парусом?

Отгремели, стало быть, грозы.

Кипарнсы

в рваных плащах

стерегут наш покой.

$$
7 \text { мая 1966, Ялта }
$$

468

Город говорунов. Говор на 0.

Горьковский, нижегородский: кОро́ва; твОро́г.

Говорят: Ока́; говорят: пОка́.

Ну, а чего посущественней, не говорят пока.

26 ноября 1966, Дзержинск 
Улицы со ступеньками. вырубленные в скале.

Удивительные деревья с шипами на стволе.

А как тебе нравится, погляди-ка, вон та блондинка-невидимка Алушта, Алупка, Евридика?

$\rightarrow \quad 8$ мая 1966, Ялта

443

На цветной фотография - мирная зыбь разминированного залива.

Поразительно красива помесь

розового и бирюзы.

Разноцветные зонтики на берегу, силуэты, силуэты.

Этот снимок я в памяти сберегу. сохраню его в честь Победы.

Май 1966, Ялта

Половой вопрос, и половой ответ

играют немаловажную роль в жизни общества и отдельного

индивидуума;

видимо-невидимо

индивидуумов ингересует половой вопрос и половой ответ.

Мне уже за 50 лет.

Видимо.

мне уже не получить

на половой вопрос

половой ответ.

9 мая 1966, Ялта 
Cтакан томатного coka 10 копеeк.

Стакан виноградного сока 20 копеек.

А ну, шаляй-валяй, на копесчку газировки, давай, наливай газировочки на копейку!

Kопеечка, копеюшечка, копеёшка, а до реформы это было 10 копеек.

Поедем в Никитский сад, помянём Никиту на гривенник, на двугривенны,й, на полтинник!

12 мая 1966, Ялта

\section{5}

Лежу и думаю: вот так и сдохни.

Мне 53 года. Слиником поздно.

Но лучше поздно. Да, вот так - лежал

и думал. И не помню, как заснул.

Я умер ровно 29 лет тому назад.

Назад -

тому -

лет -

$29-$

ровно -

не е вернуть. -

Но я растоптан как плевок.

Я не плевок, Я человек.

Мне 53 года.

Нет, пятьдесят четвёртый!

Ночь на 15 марта 1966, Ялта

455

Мы незваные гости.

Здесь мы гостим.

Здесь бывал Маяковский.

Здесь был ГОСТИМ.

На Трухмальной площади, через дорогу от ресторана "Пекин“. 
Я лежу животом на гальке.

За спиной недалекое небо.

Ветер делают крыльями чайки.

Загореть бы, как негр.

И как негр, лежу.

И лежу себе, и гляжу

на ленивое море рябое.

И светлею душой,

и в рябое море

я как в землю вхожу.

5 мая 1966, Ялта

448

Этого я не пойму.

Нет, я не верю.

Горы

плывут в дыму.

Розы

растут на деревьях.

В тьмутараканскую

TьMY -

розовое дерево.

Нет, этого я не пойму,

вижу - глазам не верю!

Май 1966, Яıта

449 a

Утро,

а через двенадцать часов будет вечер.

Девочка с бантом на голове ловит мячик.

Девушка, хроменькая, как я люблю, стучит каблучками.

Старуха, лет на́ десять младше меня, зырит в окно.

20 июня 1966 
На одной струне, на чудно́й стороне, на единой-двуединой. что не врозь, то воедино, что не врозь, то брось. а тебе не все едино?

И еще, и еще. и еще пото́; может это сам Хайам что то шепчет шопотом. И теперь я Вийон, и теперь Верлен.

Поцелуй моё перо, Гийом Аполинэр!

14 сентября 1966

\section{7}

Кусочек Сочи.

Вот женщина, предел моих мечтаний:

с бесстыдными мешками под глазами. с бесстыдными глазами над мешіками.

Она в неоновом нейлоне на лоне новой гостиницы Магнолия.

Еще кусочек.

Еще по Сочи ходит старичонок, заглядывая в глаза девчонок, отворачнваясь от старух, так не похожих на его когдатошних подруг. Спи, мальчик-старчик.

6 охтября 1966, Сочн 
Дико, как „по́pгфель“ и „ква́ртал“" чайки кричали: „три Кварка!

Три кварка, три кварка!"

Фи́ннеган, Гелл-Манн, три кварка, пиковый Германн, три кварка; бред! гениально! конгениально! Три кварка! Три кварка!

$$
10 \text { октября 1966, Сочn }
$$

466

Бывают

чудесные дни:

все дети - со мной;

все дети - при мнс;

все дети - мои;

а дым - или пар - из трубы

в такие - воскресные - дни

белей

моей седины.

I ноября 1966

467

Как русский, любящий "зачем“, „куда“" и „вот", порой я сплю и слышу: йля лят!"

Пан, иля лят!

И я смеюсь, смеюсь во всю, Как той весной, когда мне в первый раз присиился этOT СОH.

24 ноября 1966

- Сколько лет (польск.) 
На сетчатке глаз - сухое дерево.

Сигналы, сигналы.

Буровят, муравят.

Окисляясь, обрапlаться в прах.

Нет, не хочу.

Лучше так: ствол, ветхий завет. снова дал зеленый свет.

Славкн бормочат

на семи языках:

свят свет с веток!

Swit! Swet! Swiat!

9 ноября 1966

478

Весна

проснулась!

Она

коснулась

слюды

и соли,

воды

и воли,

и ВСяКой Хвори -

свищей,

простуды -

весна

коснулась,

весна

проснулась,

весна!

2 мapta 1967 
О ком я поведу рассказ?

О нас, о вас, Могиз, Мосгаз,

Мосга3, магАзин, по мозгам,

Москва, Ногинск, Электросталь,

Черноголовка.

9 февраля 1967

480

На дороге,

у Оруда "

я увидел

чудо-юдо;

чудо-юдо,

ты откуда,

из-под снега,

или с неба?

Обернулось

чудо-юдо,

улыбнулось

чудо-юдо,

и сказало

чудо-юдо:

- Энзы-брэнзы,

я из Пензы.

3 мapta 1967

- В. Бурич переделал на „где запруда“.

Опублик. в детск. хнижке „У медведя на бору“.

483

Чертёжних милый,

ты, должно быть, славный малый!

С тех пор, как твон зафонарели рифмы,

мне легче жить: я не один в безумном,

безумном, - или нет, - в разумном

мире!

6 мapra 1967 


\section{Памяти Бурлюков}

Умер Додя, 84 года.

Трэба, братцы, помянут его.

Жили были

Додя,

Коля

и Володя.

А теперь не осталось

никого.

Только Генрих голосит псалмы.

Только Рабин выдаёт холсты.

Только Гробман,

и Айги.

7 мapta 1967

490

\section{Илюшке пятнадцатый день}

Илюшке сегодня пятнадцатый день.

Смотри - он уже не мордарик.

Чегойто мальчиічка у нас похудел.

Эй, бабка, скорей очки надень:

обкакался твой государик!

1967

492

\section{Назвали Ильёи}

Неправильно 'ебя, парень, назвали. Ильёй, а надо бы Мордарий:

щекастый лобастый, губастый.

даст Бог - не в деда, горластый.

Колдуют над дитём - забава! -

злая тётка, и злая баба.

Вот, если бы... ну, да ладно, . кого нет, того и не надо. 


\section{Илюшке девять дней}

Чго ты вякаешь, Илюшка?

- Ля, ля, я лягушка;

я гусёныш, ля, ля.

я вашы сын Илья.

Дед противный, никотинный не коли меня щетиной.

Да что ты, Илюшенька, меня к тебе ведь близко не подпускают!

500

\section{Илюшкины дела}

- Дед, не говори.

- Дед, не кури. -

Так я же в уборной!

- Дед, сбегай за борной кислотой, за укропиной водой.

3а доктором...

... Ясно - определённо -

у Илюшки делов-

будь здоров.

а у нас всего-то делов -

пеленай да перепелёнывай.

С добрым утром! - ля, ля.

Кто напудил? - я, я.

Кто написял? - я. я.

Хочешь сисю? - ля, ля.

503

Иля, скажи: 6абка-кацалка.

Иля, скажи: дедуля-жидуля.

Скажи: я не русский. не еврей, я Илюшка-дуралей. 


\section{Мыши и кот}

Пришёл Илюшка - а в доме мыши.

Достали бы коlıку - а в доме ИлюІІка.

Дса.

оборотись котом.

полезай в по́дпол за мышо́м.

загрызи его, мыши́, стальными

зубами вставными!

501

Обо всех пишу, про деда нет.

И о маме, о маме не пишу.

Стала дочь моя мамой. А я сам дед.

Я на внука дышу не надышусь.

Внук, а внук, сделай пукк.

Внук, а ну - барамбук.

Внук, поддай мне раза.

Внук, закрой мне глаза.

2 мая 1967

504

Кого она любит читать?

Наверно, Жюль Верна.

Умеет рулить, и стрелять,

и плавать, наверно.

На набережной, наедине.

и голос знакомый.

Прошла, и напомнила мне кого-то, не помню.

3 aвrycta 1967 
506

Запускали в космос

Джордано Бруно.

Запускали Жанну д'Арк.

Запускали католиков и космополитов.

Ицик Фефер, космонавт. привенерился на Марс.

Даниил Хармс -

на кольцо Сатурна.

5 мая 1967

507

Ржавые овцы

В районе Джанкоя,

ржавые овцы.

Плавает

солнце

в пыли над Джанкоем,

в пыли

над Джанкоем.

Вдали

потянулся табун

с водопоя,

табун с водопоя.

5 мая 1967

519

Эта видимость смысла в стихах современных поэтовсвойство синтаксиса,

свойство великого русского языка

управлять государством;

н ты

не валяй дураха:

noka

цел,

помни об этом! 
Светлой памяти Конст. Вагинова

$$
\text { и Ero Ученикон " }
$$

Мяло,

зудило,

совело,

сводило

примеры

и домыслы.

Мало-помалу

и дело без дела

отождествлялось

B автобусе

седьмая

сигнальная система.

4 июля 1967

c 509 no 538, 506

510

В Волокаламском скопе

клёпок и капель

на буферах перетряхивались

кисти и пясти,

на короеде капроновом -

cыnb

и насыпь,

в красном тазу перед съездом -

сырная пасха.

Капли

паклей морило,

ckatka

скакала за шпалы,

и оттопыренно-мылко

зубы из тины стяжали.

3 июля 1967 
511

Хаи

Хармс

и Введенский.

Пасxа.

Воскресает лес.

Ржавый пень" -

и тот воскрес.

Но эти двое -

не воскреснут.

4 июля 1967

"В антология „Белград“" (1977): Сраный хмырь - ...

513

Не троньте,

он из отставших,

он - рохля,

он не подсказчик.

Подсказчик!

Подсказчик жидовского торга, колбасник!

Попался, который кусался, ну, Вася,

и в тымь при дороге втридорога.

5 июля 1967 
Шумыко" сказал:

"местечковый базар."

- Так и сказал?

- Да, так и сказал.

- Он, можбыть сострил?

- Да, можбыть сострил.

- А больше он ничего не говорил?

- Нет, больше он ничего не говорил.

6 нюля 1967

•В книге Я.С., Хочу ли я...: „Громыко сказал:"

515

Отчего

и почему

Bcë

кончается

на $\mathrm{Y}$ ?

Всё кончается на

y:

умер Kрymm;

и $я$

nompy.

30 чюля 1967

522

Полегоньку дышу,

помаленьку пишу,

но шедевров последнее время нет.

Нет,

последнее время шедевров нет.

И откуда им взяться?

Живу, не дышу,

полегоньку пишу,

помаленьку сnешу.

$\rightarrow$

15 мюля 1967 
516

Физики,

схватившие тебя за горло,

и химики,

воззвавшие: „судью на мыло“, -

это не исключение,

это -

норма,

так оно испокон веков было.

Божий страх.

гребущий

слух и дух -

бредни

полудурошных старух.

14 нюля 1967

\section{3}

У, как сыро и хмуро;

как скудно сочетание:

ключ и свеча.

Я сижу неумытый.

Мне смутно.

Что ли, Фофанова почитать?

24 июля 1967

525

Ух ты, вот это да!

Вот это клюква!

Вот это ни фига!

Вот это клилсы. Вот это фикса!

Полундра, ах ты, тундра!

Мездрястенькая, ноздрястенькая, не девка - скатерть-самобранка, ты - русская, али невесть какая? 
Я из Беккета. Я Гого.

Разуваюсь

и жду Годо.

А когда-то я был поэтом.

В пьесе сказано и об этом.

2 aвrуста 1967

532

Клянусь.

Я сюда не вернусь.

Скорей сквозь землю провалюсь.

Растаю, как дым, растворюсь, морося, на всё и на вся.

На всё и на вся!

27 июля 1967

541

\section{Бабель}

Всё убито тишиной.

Закинувшись навзничь.

Синяя кровь лежит в его бороде.

Как кусок свинца.

Благословен Бог Израяля

избравшего нас между народами земли

под чёрной снастью неба

под дырявой крышей пропускающей звёзды.

Захинувшись навзничь.

В канаве.

Разрывая завесу бытия.

Там и свиньям человечества".

$\rightarrow \quad 6$ декабря 1967

- см. Bторое послание Петра, 2, 21-22 
Бабель

Рукописи его неопубликованных произведений исчезли.

Тщетно искала их вдова писателя, не похожего на писателя.

Благословенна тщетная свеча, благословенна Революция, избравшая нас между народами земли, -

писал Лютов, Исаак-ІІророк

Учения о Тачанке.

Благословенно пятилучие, избравшеее нас между иародами земли.

На улицы! На улицы!

Станцуемте! Споёмте! Восстанемте из мёртвых! Гит Йонтыф! Гит Йонтыф! Гит Йонтыф"!

$\rightarrow$

9 декабря 1967

- С праздником.

\section{3}

Читатель-чего он хочет?

$\mathrm{OH}$ хочет, насколько я выяснил, по-э-зии, то есть неясных мыслей

и звуков клокочущих, В ухе щекочущих.

17 aвrycta 1967 
535

С мычащими мальчишками,

с замытыми девчонками,

со смогами

покончено.

Перегорели лампочки

во всём созвездии,

мы - чачия

мальчики,

за-мытые

девочки.

7 abrycta 1967

538

Kaк тá профессорская вдова,

отдававшаяся потрясно,

вся в слезах,

как витрина овоцного магазина, -

Ták я

настранваюсь произнести слова:

- Лида! -

или

- Галя! -

Ты моя лебединая песня, -

Песня песней!

10 нюля 1967

\section{4}

Она не хотела пилить дрова.

Она вообще не хотела пилить дрова.

Она хотела колоть дрова.

А я не хотел колоть.

я хотел пилить дрова,

пилить, пока была цела пила. 
Bc. Hexpacoвy

На улице

- сфинксы -

- мосты -

- торцы -

Алиса из-за кулисы показывает язык.

Он говорит: Я-Блок.

Она: Купи́те ябло́к.

- музеи -

- дворцы -

- больницы -

двоюродные близнецы.

27 декибря 1967

575

А ну, кому там вздумалось, что Ян ещё дитя?

Он дед уже. он дед уже,

он дед уже,

хотя

красотки в парикмахерской,

которые стригут,

его ещё не дедушкой -

папашей зовут.

$\rightarrow$

5 мая 1968

576

В пропыленных бронхах Москвы, впопыхах Ямских -

зелень,

зелень,

дйлинь-динь,

дилинь-динь,

динь-дилинь,

мы не едем выи Крым.

$\rightarrow \quad 5$ maя 1968, Поезд Москва- Симферопопь 
Алёнке
Глазами - глазеть.
Глазами - в глаза.
Глазами - к себе.
Глазами - в себя.

Затамваюсь

в окне.

Затаиваюсь

В тени.

Затаиваюсь

в стене.

Затаиваюсь

в себе.

29 декабря 1967

570

А недавно в японской Америке приземлился невидимый шар. Прилетели на Землю венерики и попали как раз на пожар.

O, как сложен процесс горения с венерической точки зрения.

3 апреля 1968

592

Симанович-старик за селёдкой стоит.

Симанович-старик, за четвёркой сходи.

Обойди мою обиду, полюби мою свободу, соль и сахар, напоследок дайте асало́ду

(Симанович-старик в Вострякове зарыт). 
Благопристойный,

пахнуццй чашлыком и гивом,

В шиве дке,

с феской на голове.

пожилым арабом

вышагиваю набережную.

время от времени

извергивая дым из обеих ноздрей.

в шортах,

в шведке,

В полном блеске,

В веском мире причин и следствий.

23 мая 1968, Ялта

580

Приветствую вас, эюигончикн, чистенькие, как бибигончики, гульским Левшой подкованные. в "Юности" опубликованные.

Вот мелкая козявка - Кушнер. Среди чухонцевых он Пушкин.

Изящные, как японцы. лупоглазые и лопоухие, вот вы-то н есть ничевоки ничивоки инкомуки.

24 МЕНА 1968

598

Знаю, что люди - звери. только не знаю, все ли.

Может быть, эти - не звери?

Может быть, дети - не звери?

Знаю, не знаю. верю, не верю.

15 сентября 1968 
Я не поэт.

Не печатаюсь с одна тысяча 938 года.

Я вам не иравлюсь.

И. наверное, уже не исправлюсь.

Но я знаю: вании важные стихи -

это маловажные, нсважіыс стихи.

Их печатают, печатают, печа...

Так покладу я вам копыта иа плеча.

нет оригинала

602

В инфекционном корпусе.

жёлтом и бслом,

доктора́ и сестры

заняты делом,

пйа дэсидэриа

ха́бэас мо́ртус,

В инфекционном корпусе,

В инфекционном корпусе.

4 октября 1968

607

Надоела Земля и Воля,

честь и нечисть,

Семья и школа.

под копытами

рык и гром -

рок'нрол,

ракетодром.

Едет

Игорь Сергеевич Холин,

едет в космос, - а что такое?

2 ноября 1968 
Все, что неправда - зачеркни.

Пора

прощаться с дочерьми.

Не плачьте.

не просите остаться,

простите,

пора проццаться,

а в гробу -

куда

спокойней одному.

22 ноября 1968

636

А. может быть, мерило веры тревожные гудки

за выморочными перилами Грина?

Моторы, может быть, зерносушилок.

и розовая сигнатурка,

способная преобразн.гь...

Но в этом никто не уверен.

Никто

не уверен

ни в чём.

20 нюля 1969

637

Я отгораживаюсь от вас, раз, два, три, четыре, пять, шесть, я отгораживаюсь, дождь

тарабанит по спине, хотя,

не так ли,

нет,

теперь ни капли. 
В заключение

поучение:

заключение

В поучение

и учёным

и простым заключённым.

10 охтября 1969

640

Черноморское побережье, подороже, подешевле,

подвесные мосты -

Хос-та, Кудеп-ста -

просто прелестно!

просто прелестно!

20 октября 1969, Хоста

642

А чего сто́ит свежеиспечённый хлеб!

ты его ещё не ешь.

только ущипнул, пошупал

на витрине, в магазине.

31 октября 1969

654

Откуда эта мелкодраматическая интонация. еще простительная Генриху от Матфея. но не физкультурнику,

не дружиннику?

Откуда же, если не от двойного подбородка

Владимкра Бурича? 
За комиссиями.

за подкомиссиями,

за перекомиссиями,

за медицинскими освидетельствованиями,

За международными событиями -

3a, 3a, 3a, -

за 300 лет до Рождества Христа

выяснено:

всё на свете видимость,

всё не истинно.

Истинны только -

атомы -

и пустота.

1969

670

В Ялте - отличная флора

и отличная фауна.

Клавочка

лёгкой трепцо́й

со скамеечки

и по тротуарцу

трёп-трёп к иностранцу, трип-трап...

28 апреля 1970, Ялта

672

Смотрюсь в это зеркало

как в подстрочник.

Глазомер жизни

оживляет глаза.

Да. старик Дриз

остался ребенком.

Только замаскировался.

Только мохом оброс.

3 мая 1970, Ялта 
Каштаны фонарей... ...хафе-шантанов...

и варьете Дра́хновски... метнулись нам в воронки

25 лет назад.

когда мы с гвардии писарем

Николкой Сусленниковым

на Ва́цлавском на́мести,

нахлебавшись сли́вовицей...

7 мая 1970, Ялта

675

Ялта

Курзал.

Борьба за мир.

Камня на камне.

Только план, и тлен телевизоров.

13 мая 1970, Ялта

678

Целый день

крутит радио

домодед-пенсионер.

И чего ему, спрашивается, надо?

Хизни

нет

и на Луне.

22 мая 1970, Днепролетровск

688

Русские по-турецки, они не элюарничают: они верят, что они Роза Кулешова и может чайничком. 
686

Небо, синее, как зяблик.

белый флигель,

зеленый ropoluek

я купил бы за грошик.

если только,

не 'rak ли,

но на эго несогласна

Ta,

чья милость - объект соблазна.

20 икли 1970

687

Чсловеколиния.

птичевек.

человек-пифагоровыштаны.

И к тому же еще муженщина, -

добрый день, карикатурист Сол Стейнберг, мистер Стейнберг, сэр.

24 нюля 1970

Мне нравится Рита Паперная.

Она - могаaссански ренуарная.

12 охrября 1970

696

Cнегурочка!

Браво-бис!

Под занавес -

раз-два-три -

трухлявая,

засветись!..

9 ноября 1970 
Bcë,

что я кричу про 'гебя

для себя.

Bсё, что я шепчу - про себя -

для тебя,

а ть́ кто?

Я?

\section{Mapra 1971}

707

Удивляетесь.

что Межелайтис!..

Не удивляйтесь.

Удивительное

не удивительно.

Удивительно

неудивительное.

27 февраля 1971

711

Крой с левой.

плёвое дело,

мы среди врагов-друзей.

копыт и костей Шершеневичей, Малевичей, Зданевичей.

Мир не скрипнет

и не пикнет,

но содержание к форме

прилипнет, как писал Игорь Герасимович Терснтьев", вредитель.

4 апреля 1971

"В книге „Крученых грандиозарь“. 
Угадайте, что бывает.

После того, как бря́нще склю́нется, а гребетня́ покочерга́ет хлы́ныы ?

5 аиреля 1971

Чго я вам оставляю?

Письменный стол.

Вид из окна на мостовую.

Пять тысяч строк.

И эту портативную летучую мышь

с клавишами № - /": , ? т

2 мลด 1971

719

Ускорение сил старости.

Пятый год - нивро́ко -

греюсь

сбоку-гірилеку

своего внука.

21 июня 1971, Днепропетровск

724

Два человека,

два - читателя-не-читателя

писателя-не-писателя-

Карл

Давыдович

Арон"

и Владимир Ильич Лс-

йбсон."

$\rightarrow \quad 24$ сентября 1971

- Работник издательства.

- Критик. 
Адепт человеколюбия

a lá Tиманиук,

врач, врач, присягни,

забожись по-московски.

13 июля, Электросталь

727

Осыпаются

цветы акация...

Этот город возбуждаег меня.

как женщину сзда на колесе.

30 мая 1971. Днепропетровск

732

Воняло, вопило:

ворвань... Ванька вор...

Вдруг

вылупилась... валсрина;

Вилюй! - и вышла вон.

29 октября 1971

734

Не увижу

ни Шиву, ни Будду.

В Ромодане

и то не буду.

Ну и ладно -

шóko и ма́рме",

рахат лукум!

$\rightarrow \quad$ "1 ноября 1971

- т.е.- шоко-ладно и марме-ладно 
Шолом алейхем, Шарм аш Шейх. Шолом алейхем, Иерушалаим, здоровья желаем, здоровья желаем, здрам жлам!...

6 ноября 1971

747

Умер старый король.

И не стало короля.

А какие были сладкие-сладкие помнишь? -

Капли Датского Короля!

17 январн 1972

\section{8}

Бывают художественные сны, бывают документальныс, многосерийные, и короткометражные. Пенсионеру снится: командировочка; поселковая гостиница; кафе-столовая:

на заводе маята:

я внедряю титановую эмаль, а главный инженер, товарищ Мурахвер и я убываю.

Бывают художественные сны, бывают научно-популярные.

22 января 1972 


\section{ОДНОФАМИЛЬЦЫ}

поэма

Посвящается Юзефу П.

\section{Yactb 1}

Нечего сказать

подходяпая эноха -

пресловутая Солоха.

Tak много

в колее лежащих

сказуемых и подлежачих, что начинаешь остывать, и начинаешь забывать, что надо жить, надо сущществовать.

Скользят машины по шоссе и, выйдя со двора, Зданевич" смотрит на часы, и видит, что пора, nopa. давно пора...

Пошел ! - завел свою волынку под сурдинку как раз когда, серёдка напюловинку, сентябрь, ноябрь, декабрь, а там и февралю... ну, во-от!- о чем я и говорю.

•днофамклец

Yacro 2

- A где ты жил?

Там, на Плюшихе.

Дом видно со Смоленской площади, только окна во двор.

На этажерочке лежит улика из улик - дневник.

Нет, лучше наповал, чем лесоповал! 


\title{
Чaсть 3
}

K чёрту!

Сил болыше не было терпеть. когда ему

открылся Миф о втором дыхании.

- Куда я. собственно, бреду -

неважно; на снегу

лежи' тяжёлая луна

и, ах, какая глубина, -

когда 6 не твердь среди воды...

И был вечер, и было утро: день второй, вторник.

\author{
Синявский \\ или Солженицын. \\ но, в общем, \\ ИХ однофамилец \\ стоял на корточках у ручья; \\ плечо струилось в два ствола.
}

\section{4actb 4}

И вот - Зима.

K заиндевелому железному листу

пристил - пятак.

.. Архангельской области.

КоноІшский район,

деревня Норинская

тунсядцу Ливішицу, до востребования.

К холсту.

как палыцы, прикипают лица

безвинно убиенных.

А пятак, Оскар,

закатывается

3а Мандельитама.

за „Закат“ Бабеля,

за зону,

за барак.

написанный на заднем или на переднем плане.

На этом автор ирощается с мертвыми и живыми героями

Конец

В позме использованы фрагменты из соч. 63 и 64 г. 


\section{9}

Маленький мальчик.

играя в слова,

выстроил башню.

Вот уже́ - до поголка.

Выше - даже - чердака.

Ну, а небо - чей этаж?

Поэта же!

$\rightarrow \quad 28$ январн 1972

751

... Голод ие довод.

Надо быть сильным.

Музыка, принеси мне

могиндовид

из Иерусалима.

"I февраля 1972

752

Умер старик.

Не рак, так грипп.

11 февраля 1972

772

Эту девушку или женщину я видел в мастерской Купермана.

Она молча восседала на табурстке.

Она ни на кого не посмотрела.

Она истекала красотой.

14 ноября 1972 
Проснулся рано: третий час.

Какой сегодня день - среда, четверг? Или четверг вчера?

Не спал, крепился до утра.

21 ноября 1972

774

... из-под полы, из кофты, из запаса"

она сует мне

много жира, много мяса,

и я давлюсь,

я обжираюсь до икотки,

но это только в мыслях,

в биотоках только...

21 ноября 1972

- посыл - „н за пазухи“

777

Ел филе.

Пил „біле“.

И болел за Пеле.

2 февраля 1973

778

Радуюсь только цветам, одними цветами любуюсь;

плоды... - да ну их!

2 февраля 1973 
НЕ ВСЁ ПРОПАЛО.

А и Б сидели на трубе.

А упало, 5 пропало.

Что осталось? - СТИХИ.

Ночь на 4 февраля 197.3

780

Эта девушка

выдыхала чистый кислород

живая, полевая студенточка

с биофака.

12 февраля 1973

784

... сядет на страницу

птица первой ноты,

а у Коломбины

вдруг отклеются ресницы,

пахнущие черникой.

- Одолжи мне сумму в ! рубль, попросила Лена Рок.

- Есть один бокал,

и тот

скоро медленно умрёт,

пояснила Лена Рок.

Лена,

жить не тяжело;

тяжело, но весело;

Эдик тоже пожилой;

ты-МОЯ ровесница.

? марта н 17 апреля 1973 
Мы сидсли у Айін.

Я забыл, чго я старик.

И заныл, заколотился

у меня на языке

узелок любви.

22 апреля 1973

786

В этом городе, как ты напомнил мне. ссть Литейные, лепныс, Крутогорныс.

И лети', летит с Лигейной улицы на Проспект

Мончик Лепский в кожаной тужурке;

столько лет уже, как Соломона нет как нет.

3 мая 1973, Дненропетровск

787

Хожу по Проспекту, любуюсь женцинами.

Синтетические ткани делают их интеллигентными.

9 ман 1973, Днепропетровск

788

Красивая девочка.

Во-первых, она на меня посмотрела.

Во-вторых - как посмотрела !

(Они проходят, и не видят

тебя- огтический обман. -

хоть некоторые из них - водят

глазами и по старикам).

1 марта и Ч мая 1973 
Продолговатое тело

ходило по Пицунде,

луть освеццая

ультрафиолетовыми глазами.

Стоят попарно

на пуги к морю

ракеты киларисов.

А что там белее'

в начале аллеи?

Отилывающая. обернись на Храм.

$$
24 \text { мая 1973, Пниунда }
$$

794

\section{Памяги отиа}

Вспомним нашего деда

на осеннем серебряном асфальте

в бывием синем брезенгвом плашике.

со слезинкой

на фиолетовой цеке.

и в зеленой, не соврать, фуражке.

14 anpens 1973

795

... Раз ! - и в дамки.

два - и в ямке...

Когда мы жили в деревне Седьмая Зона,

где сквозь солому просвечивала Корова...

14 aвiуcra 1973

796

У двушкина две руки правая и левая.

Правую он подаёт начальству. а на левой экономит.

18 августа 1973, Днепропетровск 
798 a

$$
\text { Г. Айги }
$$

Постигнув

логику абсурда,

ты любишь рассужцать

премудро.

19 августа 1973, Днепроше гровск

801

Здесь расстреляли тётю Лизу. тётю Соню, тётю Лену.

Полжизни спустя меня иривели

и ткнули носом в Место казІи.

Ночь на 10 сентября 1973

Дненроाе гровск

812

K'го тебя нарисовал?

Щапов?

или Тициан?

Ножки - во! - ничего;

и щечки - во! -

yero eule?

25 октября 1973

813

Вот кролик - мирный, как Мэрилин Монро.

Перебирает лагками.

За шкирку его!

На крючок его!

На вешалку!

На воротничок!

Мир умер. 
Прихажите Кожевникову

втоптать в грязь

соль и сахар, -

бу-сделано!

16 ноября 197.3

815

Межиров

всё время стонет,

и стенанье это

всхлипами монотонного метра

надрывает мне барабанную перепонку.

Ну, ещё, конечно,

то, что Межиров назвал „Срам кромешный“.

25 ноября 1973

816

Из поэмы

... я уважаю Baшу работу,

ваши заботы об урожае хлеба и мёда;

откуда же эта уверенность

что я всё пойму, всё прощу?

нет, Саша, нет, я не спрошу,

какого Вы года рождения:

поэтов в лесу что грибов;

я тоже моложе Рембо.

27 ноября 1973

817

Прощай, год 73-ий.

Ты нас страццал

немедленной смертью всенародной.

водородной бомбой.

А чем нас встретит

74-ый.

13 декабря 1973 
А я прочёл у Бслого,

у Андрея Белого,

П10-русски, І10-апрельски, по-еврейски:

„ручей, - прочёл, - разговорись, разговорись, душа моя, развеселись, воскресни!"

2 января 1974

819

... колебания поколения...

индивидуальная коллеІ'иа/ьнос'Гь...

... Вы слыхали? - Мишин член-плен!..

II января 1974

820

А жив ли Чукалин.

Иван Иваныч, тихой, как говорится, саной

подвигавшийся к званию, степени, или же был

да весь вышыел?

29 января 1974

821
A. $\boldsymbol{\Omega}$.

Ему с фамилией легко.

его фамилия Лойко,

почти Махно, почти Шкуро;

а, все равно, нехороино.

6 февраля 1974

826

Все заминки, заминки...

Со сверхзвуковой скоростью вылетают мысли из головы.

Так что я хотел сказать?

19 февраля 1974 
Одни говорят:

в эпоху Солжсницына

анггсемитам нет числа.

Другие говорят:

в эпоху Солженицына

антисеми'там I'рош цена.

Не знаю, кто прав, кто виноват в эпоху Солженицына.

6 февраля 1974

823

Мие и хочется, и не хочегся смеха ради посорсвноваті,я с мухачами - с Олегом Чухонцевым, да со Злотниковым, с Ряпіспиевым.

Правда, я не люблю „эзоповского языка", не примсняю. Даже позднего Заболоцкого как-то не воспринимаю.

И, взметнув до небес оперенье", как петух в его стихотворении, я кивну мухача́м: - до свиданья, мол; ухожу из преданья в преданье.

12 февраля 1974

"Петухи поют".

828

Aвтопортрет.

Лыс, как Михоэлс. Сипл голос, негромкий, Вот он, записанный на пленке:

- Еауы-ь! Воды-ы! Земли-и!

Себя...

18 марта 1974 
В книжном магазине на углу Ар'гемовской и Проспекта перед войной работала Берта Лацавер, Худенькая такая, с пятнышком на щеке.

... Нет, не воскреснет...

Рас'ительный покров у края льдов. мак, камнеломка, лютик, колокольчик, а то ещце - пушица и кипрей. 110 это только месяा, два, от силы, по замыслу Создателя.

16 февраля /1974/

827

Мы пошили чехлы для машины Жигули.

Как померяли чехлы - оказались велики. Ай, чехлы!

Надо очередь занять, Жигули на МАЗ менять.

14 марта 1974

829

... Ликуй, Исайя, голоси:

„Иже Еси на небесех",

а ты, Мазепа, ты, Азеф.

ты знай своё: долбай, глуши...

21 марта 1974

830

Вот Чуковский перед нами. он дельфин, и временами так пронзительно высок стародетский голосок:

- С бородой товарищ Лапич, вы не мамич и не папич, и не бабич и не дедич, только Женич Казакевич. Этот сон похож на правду, ух, как он меня обрадовал! 
Магнитное поле сирени

открыл

Пётр Вегин.

Старуха Барто возмутилась:

- Он, часом, не шизофренин?

Корнилов

или Самойлов

ввернул, что магнитное поле...

но, в общем, надоело

выдумывать, чего не было.

Попал и я

налоследок

в магнитное поле сирени.

Ночь на 24 апреля 1974, Ялта

832

... вспомнились

полевые васильковые

Пресвятые Девы Богородицы

на Нижегородской,

у Холина...

28 апреля 1974, Ялта

8.33

... а, помнится,

вроде - школьница,

В тени, на исходе дня.

за светлой стеной дождя, -

ты, мертвый, лежишь под Ногинском,

душа же твоя, невидимка,

на облаке, босиком.

играет себе в бадминтон...

24 апреля 1974, Ялта 


\section{4}

Всё в порядке в духовом оркестре, дудки, капельмейстер - все на месте, звук отличный. стереофоничный, паучок на нитке - ключ скрипичный; и кружась, шагают пары на бульваре (всякой твари, сказано, по паре).

$$
30 \text { апреля 1974, Ялта }
$$

835

Местные жительницы и жители вышли на улицу 1-го Мая, чтобы участвовать в массовом митинге и демонстрации 1-го Мая; 1-го Мая над головами полно мишуры, ежеминутно лопаются шары.

I мая 1974, Ялra

836

Ты книжечку перелистал

Злотникова Натана, стихов, светящих вполнакала Поэзию разгадал наподобие жидкого кристалла; выходит, ты ещё не так стар; а, помнишь, У Мандельштама...

5 мая 1974, Ялта

837

Искать такси

туда или обратно - всё равно,

и так искать, и сяк такси;

и вот - итог:

стихи на похоронах Кирсанова...

5 мая 1974 
Антисемит антисемиту рознь.

Сейчас в цене

активный ангисемитизм.

Активный антисемит -

он и агитатор, и пропагандист.

17 мая 1974, Ялта

839,840

Александру Кушнеру

1.

Право, браво: какие пассажи берёт, знает: стих от прозы не бегает наоборот.

Надо оползень жизни сдержать. говорит Кушинер, жить, а разные мысли суметь выражать так, не слишком искусно.

9 нюня 1974, Днепропетровск

2.

Дюбовь бессониша аптека ночь, улица, фонарь, эпоха, касаясь мимолётно клавиш ты ставишь правильный диагно3, Саша.

Сегодня

Синьяк, шагреневая кожа моря

и музыка из „Ореанды“,

а завтра - город чугуна и стали

плывет в глаза печатными листами

своих изданий -

шлакоблочных зданий.

19 мюня 1974, Днепропетровск 
... переталдыкивают одно и то же, переталдыкивают в стихах и в ирозе, в периодической печати, по телевидению, по радио одно и то же...

10 июня 1974, Днепропетровск

842

...РЕЗАЛ ЛАЗЕР...

30 июня 1974

843

... наконец-то

В июль вкатилось лето;

мочёное, толчёное, копчёное как черт, В бурьян и паутину вкатилось колесом...

2 июля 1974

\section{4}

Покойный Володя Бугаевский. Помянул бы его, да не с кем.

Вот Икс с какой то полушведкой.

Вот Игрек, похожий на Бальзака (или наоборот); „Прощай, старик. поеду посмотрю стрипти ${ }^{\prime \prime}$.

20 июля 1974 
Вечер, похожий на Сашу Аронова (оставим эту метафору нерасшифрованной).

$$
4 \text { aвгуста [1974] }
$$

846

Взрывом Эдуарду Асадову выхлестнуло глаза.

Ивана Пулькина насмерть. А мне только перекарежело тонкие косточки взрывом 33 или 34 года тому назад.

$$
5 \text { aвrycta } 1974
$$

847

Не такая большая потеря - смерть мужа лет в $30,35$.

Покойный Яша, покойная Феня.

Старуха, кому ты нужна?

$$
8 \text { aвrycta } 1974
$$

848

Знакомое лицо... Анвар Садат...

Хусаинов уже не играет. Байдачный, Маховиков, Трошкин, Колотов. С аукциона в „Савое“. А рабочий начнёт воровать - получит срок.

$$
17 \text { aвrуста } 1974
$$

„Лето! Это! Хорошо!“

- пело - тело - и душа.

Оглянуться не успел, как, на детском самокате, смерть сама кати́т в глаза.

$$
29 \text { aвryct } 1974
$$


... теперь поллитра не говорят, теперь говорят пузырь...

Пейте, враги мои,

пейте, друзья мои, пейте,

простые советские люди, чокаюсь с вами

гранёным стаканом...

4 сентября 1974

851

- Ты, вша партийная, - бранилась Тёща с Зятем.

А зять обиделся за Партию, да КАK ДАСТ - бутылкой от Советского Шампанского - Старуха враз и окачурилась.

8 сентября 1974

852

Я услышал во сне элегию Массне,прелестна, как Алла Засухина

в упражнении с обручем, с лентой

в произвольной программе,

и, все-таки, в Cónote

высший балл - у вышибал.

10 сентября [1974]

853

Ках кто, а я не похмеляюсь.

Кто как, а я опохмеляюсь.

Зайлу по пути в „Гастроном“ за вином.

Нет, лучше зайти за вином в „Гастроном“.

Нигде кроме как в „Гастрономе“.

10 сентября 1974 
... когда пришли забирать дурака,

товарища моего,

нашли клочки черновика,

а больше ничего,

а больше ничего,

нет, больше ничего,

когда забирать причили дурака -

товарица моего.

$$
17 \text { сентября [1974] }
$$

855

Памяти друга - Шуры Компанейца

Лето кончается на песке.

Серая жилка на виске.

Ветер порывистый до сильного.

Небо Балтийское до синего.

27 сентября 1974

- yмep 22 aвrycra 1974

857

Опять понедельник.

опять воскресенье,

как быстро уходит последнее время.

4 ноября 1974

858

„Жирафы в Африке пасутся",

и это не игра в бирюльки, -

поэзия

игра в бессмертие.

Ночь на 16 ноября 1974 


\section{Надпись на хниге}

Никонов, староста, выпустил книгу. Собственно, Никонов книги не выпустил:

Главный Редактор, Директор Издательства визу поставят,

$$
- \text { - }
$$

Старосту, Никонова!

$$
\text { стало быть, выпустили }
$$

14 декабря 1974

860

19-ое декабря.

А сегодня уже 22-ое.

Ну, ничего, 22-ое тоже на "д".

Дед, о чем ты думаешіь?

22 декабря 1974

861

... не только в Абхазия,

в Коми-республике, где соболя

гибнут порой от мороза.

стелется

ВЕЧНОЗЕЛЁНАЯ ТРЕЛЬ СОЛОВЬЯ песни её народа.

Ночь на 30 января 1975

"Hз Canrupa.

862

Я уже НЕ ШКОЛЬНИК.

Я пошёл НА СЛУЖБУ.

Я ношу CTPEMЯHKУ.

молоток, И ШЛЯМБУР.

6 февраля 1975 
... оказывается,

победили не мы,

победили они,

а мы,

а мы поражены...

22 февраля 1975

864

Говорят, законно, 30 лет, а чуть что, так и года нет.

Как он трясся, как его трясло,

бейте, братцы, поминайте злом, -

чем он спасся? что его спасло?

24 февраля 1975

865

Говорил Андрей Андрею

в ЦЛЛ на рандеву:

- Ты меня не передреивай,

я вас всех передрею!

27 февраля 1975

869

\section{Из цихла "Новые барахи"}

Все есть: супруга, сервант, телевизор, магнитофон.

Есть интерес к жизни: чемпионат по хоккею с мячом.

$\rightarrow \quad 10$ марта 1975

871

... воскресенье, понедельник, ок-

тябрь, ноябрь, макабрь...

$\rightarrow \quad 29$ mapta 1975 


\section{Пара романсов}

Если жизнь - мираж, если смерть - мираж, ну, и что́ с тoro?

Сяду, полистаю в тридесятый раз

Шlкловского:

при царе, царе Горохе

жили-были скоморохи...

А Золушка после бала юшечки похлебала, покушала, стало быть, юшку, и прыг! - на свою раскладушку. Спи, дитятко, спи, Янина, не разбереди пианино...

24 февраля 1975

868

Я лежу, захрыв глаза, у румынской переправы.

Вижу лица блеющих овец. и слышу голоса их серебряных копытец.

27 февраля 1975

872

... воскресенье, понедельних, октябрь, ноябрь, мака6р... Ма́рт идет, апрель, шестьдесят два, третий.

Я опять летал в эту ночь во сне, Kak, когда, забыл. 
Какая то женщина.

похоже, не русская.

вошла с ребенком на руках,

но я-то ведь знал,

что мне померещилос $b$,

что это - оптический обман.

8 апреля 1975

874

После дождя

появились

на асфальте дождевые черви.

Я-то к ним отношусь лояльно,

а вот мою фрау-мадам

мутит

от одного их вида.

12 апреля 1975

875

Я хотел бы писать как Надежда Яковлевна.

Спорьте с ней, члены союза советских писателей о членах союза советских писателей.

22 апреля 1975

876

... с кем сегодня состыкуемся

по второй программе?

на ком сердце успокоится?

На Муслиме Магомаеве.

22 апреля 1975 
Шёл пешеход мимо Красных ворот прямо, направо и наоборот.

Милиционер паразита нагнал

и на Котовского страху нагнал.

25 anреля 1975

878

На Бобика Заходера

обиделся Керрол,

за то, что указаный Бобик

Алису озаходерил.

24 апреля 1975

879

Да, сны доказывают, что я жил среди людей.

22 мая 1975

880

Надпись на "Сестре моен - хизни“

Когда я перечитываю эти стихи - ко мне возвращается память.

$18 \operatorname{man} 1975$

881

... пусть ликует стар и млад! -

тополиный пух зову я:

перекати мостовую,

перелицуй тротуары

с нового

на старый лад!

1 нюня 1975 
Поселок Волошина, больше ничей.

А голуби, а белые голуби над „Гастрономом“

напомнили что-то...

напомнили То, что...

не помню что...

5 и 14 июня 1975, Планерское

883

... роз не коснусь:

выставлять напоказ

ревниво оберегаемые

заво́ "-

это стриптиз.

13 июня 1975, Планерское

-

884

Mногогорье,

многоплечье гор.

Горы буро-зеленые...

Фиолетовые...

Ультрафнолетовые...

И эта

прохладная стихия, входя в которую сбрасываешь вес,

по шиколотки...

чуть повыше пояса...

а там и с головой.

13 и 17 нюня 1975, Планерское 
... с утра так радостно,

что всё вокруг в цветах и в звуках,

а море рядом!..

У берега медузы,

и, руки запустив

в живой презерватив,

красота из Мосфильма

трясется, чёрт возьми!

7 и ночь на 15 июня 1975, Планерское

886

Кто это такой?

Это

потенциальный поэт;

потенциальный художник;

потенциальный разведчик;

потенциальный танкист;

потенциальный убийца

папы и мамы и бабушки с дедушкой.

6 июня 1975, Планерское

887

В общежитии переплетаются

положительные эмоции с отрицательными, отрицательные предпочтительно;

вспомню вдруг,

что Перцов - трегуб,

и опять погружаюсь в морские дебри,

и в морские сны, в морские сплетни.

$$
6 \text { м } 14 \text { июня 1975, Планерское }
$$

888

- Не стой с задумчивым видом, - шипела Медуза Горгона на мужа. А мать ее...!

20 мюня 1975, Планерское 
Илья Сельвинский, мастер миниатюры, в 27-ом году написал в Коктебеле "Пушторг“.

Я в его честь сочинил стихотворение. Вот: „Комплекс Паниковского (мементо мори!)“

- Топите его! Этот старик сцыт в море!

24 июня 1974, Планерское

890

Село Новосёловка;

- хлопцы, а ну, равняйсь! опять мне приснилось, чго я молоденький, с подсолнухом на плечах.

Ночь на 6 июля 1975, Новоселовка

891

Солодкий Иисус, явись, тебя зовут убийцы в белых мазанках, призревшие старух израильских...

4 июля 1975, Новоселовка

892

Родятся звуки в темноте, снуют и вьются, как во сне.

Но полусон сильней, чем сон, сине́е сосен чернота, и можно жить, или не жить (не важно, что сказать, и как).

5 июля 1975, Новоселовка

907

... и было так чисто и звонко, что казалось, снежинки летели не с неба, а возникали из воздуха... 
В утреннюю каламуть - всматриваюсь:

в баламуть вслушиваюсь;

о-тб, кажет, плавни як плавни;

а, может, то бредни? - поди, доберись

до правды; да и охота была мне...

7 июля 1975, Новоселовка

894

... а у нас сегодня клев как клев.

удим рыбку без крючков, без поплавков,

ступает солнце по стерне, машиной скошены колосья;

на новый хлеб, на Хорол-Днепр

пролейся, бодрственная осень!

10 и 13 июля, Новоселовка

895

Чумацкий шлях, чи не чумацкий, чи мать, чи мачеха? - кто знает, чи то ковыль по-над дорогой, чи сивый сон, чи сон лиловый?

II июля 1975, Новоселовха

896

Замечаю много нового.

Ког да-то писалось голярня, а теперь перукарня.

Понятно, перукарня

понятней, чем голярня.

А вот, почему-то, баня

как было, так и осталось:

лазня.

16 нюля 1975, Днепропетровск 
Ax, в мини-юбочке! всё напоказ, красиво.

А макси для чего?

А макси - для стриптиза.

15 июля 1975, Днепропетровск

898

Решаю ребусы Бориса Пастернака.

0 , как в них непонятное понятно, понятное непонятно.

A горечь тубероз, небес осенних горечь, а также вечеров, ночей и людных сборищ лишь доказательство свободы воли.

18 нюля 1975, Днепропетровск

899

Весь город, и Чечелевка, и Кайдаки, просоленные металлургическим шлаком, где мы гуляли в обнимку когда-то, где мы любили стихи Пастернака,прощайте, отныне навеки !Я даже не кинул копеечки в Днепр...

Ночь на 21 июля 1975 поезд Депропетровск - Москва

900

... захотелось-БЫТь!

захотелось- знать, как сыграл с Кайратом Арарат, и какие новости у вас, в Москосмосе.

(Вот чудак Шекспир!

Разве может быть вопрос:

БЫть

ИЛИ НЕ БЫТЬ?)

26 м 27 мюля, дома 
Когда я стал лысеть, это был

УДАР СУДЬБЫ... ...и девочки,

которых я уже почти что не хочу, которых я хочу. но только платонически.

15 asrycta 1975

902

... хорошо бы мерку снять...

надо всё, что сверху, снять...

Вынимает свой аршин!

- КТО ВАМ РАНЬШЕ ШИЛ?

I сентября 1975

903

... философ Анри Бергсон умер в 41-ом году, Франция уже два года воевала, а я думал - это что-то такое, что еще ДО 13-го года. Потому, что до 13-го, ДО моего рождения, ДО моей жизни - это абсолютно не то, что в 41-ом или, допустим, 21-ом году. В 21-ом у нас во дворе, в сортире повесился какой то дяденька, на Украине был голод, до сих пор помню, кахая это вкуснятина - макуха или „жмых по-русски сказать". Мы боялись заскакивать в уборную, в низком ящике у входа жрали что то свиноподобные крысы, мы хлопали и хлопали дверью, мы кричали: - пошли вон !- а они не уходили, только зырили на нас. Еще через десять лет я в Университете проходил Канта и Лавуазье, а в 41-ом осенью драпал через Херсон до Мелитополя со всем своим взводом на грузовике. 


\section{Наука умеет много гитик}

Космонавтика - наука.

Кибернетика - наука.

Сексология - наука.

Вот оно, какая шітука.

15 сентября 1975

905

Лунная ночь глубока, сказал один японец.

Нет, сказал, конечно, не так.

Наверно, не так и подумал.

29 сентября 1975

906

Опусти глаза.

Листья падают, приговаривают:

скоро зима,

с мо-ро-за-ми...

Листья падают, листья падают, просто так, Христа ради...

7 октября и 19 декабря 1975

906 a

Листья падают, листья падают, просто так, Христа ради...

19 декабря 1975 
Гаспаров перевёл Светония.

Переведите меня!

Переведите!

Пере...

... тише, с ума сошёл,

вот до чего дошёл.

14 октября 1975

909

... на ихнем знамени

звезда в лузе...

17 октября 1975

910

Такая славная пора,

с утра $6^{\circ}$ тепла,

прошёл циклон, антициклон,

а сейчас идёт футбол.

Кто играет? Киевляне.

С кем? С Давидом Кипиани.

24 октября 1975

911

Друг у друга кольца крали,

часы воровали,

тут и Валя Португалов,

нет, Варлам Шаламов...

что ты, ветер, это враки,

вралейшие враки,

это рифма, сволочь, гадит,

ты не верь ей, братик!

7 ноября [1975] 
А ну, катись, а ну, вались, йодное небо, лиловая слизь, а нет, так засыпь меня мёрзлой землёй, засыпь с головой, повозись со мной, подруга-Осень...

\section{7 ноября 1975}

913

... пока нас не выселили в Биробиджан...

15 ноября 1975

914

а, В сущности, ничего не надо, кроме, как произносить слова, например, порубка, плоскодонка.

17 ноября 1975

915

... мякоть парного снега,

без неё как без хлеба,

я хотел сказать как без Бога...

Ночь на 30 декабря 1975

917

- Детство, отрочество, война, „разговаривая с самим собой, как с посторонним“• входит старик,

жалкий, как черновик.

Так что давнее сдается давешним.

$\rightarrow$

15 января 1976

- Из переведенной прозы 
... плюс отрицательные эмоции

минус положительные...

14 января 1976

918

Весело, звонко;

вечером блямс фонари об замёрзшие стекла вдребезги.

18 января 1976

918,907

Весело, звонко;

Вечером блямс фонари об замерзиияе стекла вдребезги;

и было так чисто

и скользко,

что, казалось, снежинки летели не с неба, а возникали из воздуха.

18 января 1976 н 12 охтября 1975

919

Перепутались в голове собрания сочинений Достоевского и царь с картины, где он сына убил.

20 января 1976

920

Жизнь - трансформируется - В сон

Жизнь - трансформировалась - в сны.

21 января 1976 
...и многие, многие другие...

10 февраля 1976

\section{2}

Как его только не величали!

И „жидовская морда“,

и „враг народа",

и „беспартийный большевик“!

12 февраля 1976

923

Тухачевский?

А, может быть, Хатаевич?*

Попрощаемся с Хатаевичем.

Попрощаемся с Тухачевским, переписанным на маниинке репрессированной машинисткой, со всеми прощаемся.

5 мapra 1976

- Секр. обкома, умерший в Дн-петровской тюрьме.

924

Вот кому́ я стараюсь не показывается на глаза: товар Либст "... шурша сереющим убором..."

"... косыми поведёт глазами..."

"... скука..."*

13 мapтa 1976

- Л-т ред. работник. Цитаты из М. Кузмина 
925

Ках солнечные пятна, как ба́ю-баюикки-баю̆ "понятно“ - „непонятно“. 12 апреля 1976

926

ты, мастер спорта, многообещающая (миллионам зрителей) Т.П., сейчас я тебя выключу.

20 апреля 1976

927

\section{„А был ли Иван Ивановнч?“ \\ Назым Хикмет}

- Эй, товарищ генеральный секретарь, полезай на пьедестал!

- Не полезу...

- А я говорю, полезай!

- Ну, разве что...

24 апреля 1976

933

На Ваганьковском - Сергей Есенин, где-то там - Иосиф Мандельштам, всё равно - и тут, и там персть рассеяния, а на Краснопресненской заставе, как и на ином плацу, с песнями встречая старость, юность ржёт - и это ей $\mathrm{K}$ лицу. 
Утречком

пернатый интернационал,

начиная С "пинь-Іиянь"

и кончая "чиочиосан“, „чиочиосан“, окхупирует Электросталь и окрестности.

25 апреля 1976

929

Я хочу написать сто романсов,

о, романсы, ах, романсы, ну, не сто, не полсотни, я согласен на десять, пятнадцать, на пять романсов.

26 апреля 1976

930

Один американец" сказал:

„лучше я буду петь народные песни протеста. чем сидеть, как Шопен, на своей изысканной заднице", сказал один американец. У, жопа!

30 апреля 1976

-К. Рэкочи (пер. Б. Британишского).

931

От картофельного поля, от твердеющей ботвы чернобелые дальтоники обращают к небу лик, яко еси насытил нас земных благ...

17 мая 1976 
Говорила Марина-царица

Цветаева:

- Сильных не боюсь - борюсь

Самым, разве, поддаюсь слабым *

$$
18 \text { мая } 1976
$$

- Нет, это не цитата, и не пересказ.

934

Любить... молиться... но... бежать...

чтоб в океане...

Иннокентия Анненского

музыкальные паузы,

многоточия...

30 мая 1976, Феодосия

935

Да, поэзия синтаксис, но и порядок рифмовки

играет немалую роль:

AвAв, АвAв, и вдруг АввA!

30 мая 1976, Феодосия

936

Выдача корреспонденции до востребования.

Какой-то птичик прилетел,

и требовательно, гак требовательно -

затребовал,

что, вытребовав, наконец.

- ввысь! - и улетел.

30 мая 1976, Феодосия 
... светает, слава Богу!

Воробьи

уже заводят, завели

свое „Живешь? - Живу, - живи!“

31 мая 1976, феодосия

938

В двусветном воздухе Феодосии

как души умерших полощатся крыши;

о лебеди́во;

о озари́;

о человекочайка!

2 июня 1976, Феодосия

939

Я теперь по ночам в "Феодосии“" предаюсь, так сказать, философии.

Море рядом, может, в ста шагах, можно вниз по лестнице сбежать, а, как сказано у Маяковского, кто над морем не философствовал?

Ночь на 4 ноня 1976, Феодосия

- Гостиница

Из Анненского

Изнемочь...

невмочь...

пусть будет солнце или...

ночь

надвигалась ощущением провала,

то и дело железную цепь задевала...

4 июня 1976, Феодосия 
Главное иметь нахальство знать, что это стихи.

4 нюня 1976, Феодоскя

942

Из друізей у меня остались две-три книги, да и те

исчезают

из поля зрения.

4 июня 1976, Феодосия

943

Годовалая бледная немочь - наш внук - на „солёном пляжу“ пересыпает, пересыпает, пересыпает песочек.

Это его музыка, его Лист или там Мендельсон.

Его живопись или графика, его архитектура.

Моя поэзия!

5 июня 1976, Феодосия

944

Свивались, бились,

всю жизнь мне снились, снились

бабочка газа"

и скука, чёрная зараза".

8 июня 1976, Феодосия

'Из Анненского.

945

В пдоме Грина"? - да при чём тут

Грин? - и этот след зачеркнут!

Подожди... мы жили оба

в жёлтой комнате Ван Гога...

II июня 1976, Феодосия 
Крым, лицезрение твоих деревьев вызывает мускульное напряжение.

12 июня 1976, Феодосия

947

... латинский гений,

парй в трагедии Корнеля, прочти мне, море, александрийский стих прибоя!...

1.3 июня 1976, Феодосия

948

Прелестная утренняя Москва,

и каменные дома́,

и красный прекрасный трамвай!

Я хожу по Москве весь в пуху, как на старости лет некий Фет, и готов я продолжить свой путь, хоть и зыблюсь весь, и трепещу.

25 и 26 июня 1976, Москва

949

Снится" девушке вертолётик, снится.

Вдруг лошадка пробряцает по асфальту мостовой.

И тлеют звёзды.

Утро,

пусть сильнее грянет утро.

7 нюля 1976

- другая редакция: Снился... 
Ках это вам приходят в голову

двуединственные слова, которые...

И как это люди могут прозой писать, и возводят Храм на Храме?

А карточные домики, которых вы не достроили, которые - раз! - и распались, воздушные замки Поэзии.

10 и 11 нюля 1976

951

... теперь из ссылки,

с могильной шахты, на перетырку, на пересадку, в лице ни кровинки, Зинка Саввина прелестна, ках прелюд Рахманинова.

6 asrycra 1976

952

Похожий на Былинова, какого там Былинова?

не знаю никакого - ни короткого ни длинкого

Былинова,

и никакого Шехтера, -

кахого Мурку Шехтера? -

Марк-Шехтера, вот именно не знаю, знаю не'.

9 asrycta 1976

-(Былинов) Бейлинов, Шехтер - писатели, мои земляки. 
Вдруг в памяти мелькнуло: Зойка Длугач! за что - про что - не знаю что и думать,

а замечаю, что как раз

она в уме с Юдасиной слилась. своей подругой.

24 aвrycta 1976

$954-5$

1.

Проходя мимо памятника Дими'грову, подумай, а где Попов и Танев?

2.

Возле клуба имени Карла Маркса стоит еврей 1818 года рождения.

10 сентября 1976

Хорошо глазам в саду.

Сяду, погляжу.

Астры вымахали махровые.

а за ними хризантемы.

Ничего не скажешь - хороши:

разноцветные, как 20 лет тому назад.

13 сентября 1976

957

Вот - мотнуло на повороте

и в мозг вошла из тамбура в вагон

из ветра в траву из времени в прикосновение

щеки ее мокро блестели под фонарем

доказчицы, не разглашайте

20 сентября 1976 
Пока не меряешь давления.

ну да, пока не измеряешь. здоровье вроде как в доверия, и болен или нет - не знаешь.

Но листья жёлтые осыпались. зеленых мало остается. И Овсей, строфу дописывая, с лишней болью расстается.

23 сентября 1976

959

Фонари, светящие среди бела дня

В этот серенький денёк.

Ждущие, зовущие, не щадящие меняну, что же ты умолк? - говори;

или нет, не так.

- Фонари, светящие среди бела дня

В этот серенький денёк.

Ждущие, зовущие, не щадящие меня фонари, ну, опять умолк?

24 сентября 1976

960

Акация моя, акация!

Липа - та уже вся облетела,

а - наша - южанка -

тёмно-зелёная,

не тронута сединой.

Да, каждое дерево, каждую женцину хочется изобразить.

5 охтября 1976, Кмсловодск 
Здравствуйте, огромадные деревья,

с буйволовым стволом,

с лиловой шкурой, -

я с вами знаком понаслышке.

И вы,

ивы,

живы ли вы,

чи вы живы.

6 и 8 октября 1976, Кисловодск

Он и в рифму пишет,

и статьи кропает,

не поэт, не критик,

так себе, Куняев.

6 октября 1976, Кнсловодск

963

... птиц не слышно боле...

Так вот чего нам нехватало -

что живопись жива,

но музыки не стало,

и духовые деревья оркестра

молчат -

во всю мочь.

964

Кружу по маршрутам лечебного парка

и думаю о том,

что у муравьев не бывает инфаркта.

То сверху вниз смотрю,

то снизу вверх,

меняю точку зрения на жизнь и смерть.

14 октября 1976, Кнсловодск 
Чуть в полусне паутинку стряхну я, липы от ветра бегут врассыпную за Северный Кавказ. пляшут эринии на самшите. снег давит виноград.

17 октября 1976, Кисловодск

966

... семнадцатое, девятнадцатое, а в промежутке, между прочим, сбор - офицерские занятия...

18 ноября 1976

967

Заиндевев, стоят, как расстеклованные, молочно-белые деревья...

17 декабря 1976

968

... ультра + порно

равно ретро;

странно, что кто-то не понял этого.

17 января 1977

969

Свет неясный, леденистый пробивается в глазницы.

Дрожат мои мысли.

Давным-давненько-далеко отец возил дрова в сельпо...

21 января 1977 
... он для красного слова,

да нет, - для словца, -

вплоть до Господа Бога.

ну да, всё продаст...

24 февраля 1977

971

... что весенняя осень в стихотворении Ахматовой

под нижайшим небом,

перед тишайшим снегом...

5 мapта 1977

972

- Я иду домой, -

писала поэтесса,

и, как будто, правда, жёлтый

луч упал в траву

или медленно густела тень.

Жаль, что к Анне Андреевне я не пошёл.

не дошёл, не на той остановке сошёл.

22 марта 1977

973

Мутный день

с осадком на дне.

Весне нездоровится.

Bot тak:

рыл, бежал в атаку,

и не знал, сыра ли мать земля.

28 марта 1977 
Ушла на базу. А что есть на базе?

Картофеля в о 6 ще на базе нет.

$$
8 \text { апреля } 1977
$$

975

Господи, какая ночь!

Какая глыбь и прось!

И что за плавь, -

не приведи Господь!

9 апреля 1977

976

ХАРАКТЕРИСТИКА НА ЕВРЕЯ.

10 апреля 1977

977

Хмурый денёк, снулый,

и вдруг

солнышко показалось!

Нет, это тебе показалось...

4 мая 1977

978

Перевожу Винграновского, по-украински в е л и к ого, по-русски большого поэта; (Поэзия - это неожиданно открытая Правда).

13 мая 1977

983

Постоим на бульваре, поговорим за белого лебедя.

Чёрный лебедь чуть слышно... 
... да, видит Бог,

что надо прощать,

ког да слабо́,

когда сил нет отмщцать...

3 июня 1977

980

До́ма-не до́ма, сонные щебеты сена-соломы, как я хотел раствориться в России, не растворила...

7 июня 1977

981

Боже, как орут старики! -

Антокольский, Шкловский...

Хоть возьми и выключи телевизор".

8 нкоя 1977

- т.е. возьми и похорони нас, стариков.

982

Выйдем на улицу Осипенко, подышим воздухом, до Комиссариатского и обратно.

Слева Москва-река, справа канал, а теперь справа Москва-река, слева канал, два моих внука живут в Москворецком районе, Антон да Кирюша.

25 июня 1977

985

Ничего не болит. Только сердие болит.

А когда не болит, ждёшь, когда заболит. 
Старый голубь, похожий на воронёнка, на чугунной ограде

сидит, и видит, как тридцать девятый трамвай. тормознув, проволакивает меня мимо

в одном из охон...

19 июля 1977

986

С каждым днём всё ближе...

Что ни день, то ниже...

2 aвrycta 1977

987

... Ках прохлада в летний день.

богоданные стихи Ахматовой.

В голосе ее „струится холодок“".

Да, конечно. Бога нет.

И чёрта нет

Так откуда же берутся стихи. кто их нам диктует?

19 asrycta 1977

- Axмatoвa

988

Колокольчики звенят. Навстречу мне движется мечтательный рогатый скот.

Всё, что я любил, от „сестры моей жизни“ до „мы с тобой на кухне посидим, сладко пахнет белый керосин“" - всё уходит от меня, ещё не ушло, но всё уже на отходе.

Да, Сидоров здесь, Сидоров там... 
Милый друг, иль ты не видишь.

Что все видимое нами -

Только отблеск, только тени

От незримого очами?

В. Соловьев

Подумал, что это ничто иное, как ОПРЕДЕЛЕНИЕ ГОЛОГРАФИИ.

9 октября 1977

989

Будь готов! Bсег да готов!

И мальчишки

взяли Клюшки, хвать за клюшку - и на лёд.

Да, мальчишкам хорошо.

Вот когда и Возлесенский

перестал писать романсы.

Ноздри

осязают воздух

при температуре „минус“.

Подмосковье... Предзимье...

А душа ещё в Париже!

18 октября 1977

992

... расстрелян Николай,

сыпняк на всем на свете,

„Пролетарий, на коня"-

написано в газете,

Умом, понятно, не обнять,

И без бутылки не понять.

И это есть... и это ваш...

это наш последний...

$\rightarrow \quad 19$ ноября 1977 
Лошадь промчалась: - ра́з-два-три, ра́3-два-три, ра́3-два-три! Ритм такой, будто она не четвероногое, а трёхногое.

... и вот я примечаю, что без мыслей никакие слова в голову нейдут...

10 ноября 1977

991

Вот Ольга, Ольга Третьякова.

Она жена врага народа.

Но, Боже мой, какой мираж, -

да не мираж, - /какой склероз!

... Сплетая, тая... расплетаясь...

всей стаей, девочки, всей стаей!..

19 ноября 1977

993

Сегодняшний день,-

чего еще надо вам,

разные граждане,

в моем дневнике,

где пьющие - рядом, на брёвнышке,

а непьющие - прямо из горлышка?

Когда вы станете старенькими,

вы сами, может быть, скажете:

„Какое счастье, что существует телевизор,

что есть возможность иногда включать футбол,

и что порой нам представляется на выбор

кино „Блокада“ или Динамо - Пахтакор!“

22 ноября 1977

1006

Пусть победит слабейший... 
994

Так было, так будет - тяжелая желтая птица на взлетное поле садится,

с ножом, со свинчаткой, с преступной общедоступной взрывчаткой; В полдень, в солнечный день пробегал по Арбату так и жмется к ногам горбатая тень...

23 ноября 1977

995

Люди знакомые нам незнакомы, а незнакомые вроде знакомы.

Ольга Ивинская, я Вас не видел, Вы это, или не Вы?

Вечная память Борис-Леонидовичу, а „Живаго“ живым, Ольга Живинская...

12 декабря 1977

996

Я не член ни чего,

и ни, даже, Литфонда.

Мне ни мягко, ни твердо,

и ни холодно, ни тепло.

Ночь, как черная гусеница (почему бы нет?), или черная бабочка (главное - это цвет), Ночь, который час? Шесть, должно быть. Слава Богу, уже зажигаются окна напротив.

24 декабря 1977

997

Вспомнился Коктебель.

Вспомнился позапрошлый снег.

Павел Мовчан, хохол с сердоликовыми глазами, благосклонно вислухивает мои стихи.

1 февраля 1978, Кисловодск 
Вот идиотство!

Кой чёрт меня дернул зимой в Кисловодск.

И что бы я делал зимой в Кисловодске, когда бы не эта книжеонка,

кривлячка и пижонка?

4 февраля 1978, Кисловодск

999

Январь, февраль,

двадцать градусов тепла.

Прощай, нарзан,

уезжаю в Электросталь.

Я на солнышке гулял,

серых белок кормил.

Нарзан, прощай,

уезжаю в Электросталь.

15 февраля 1978, Кисловодск

1000

... kakoro

Takoro

Сергея Третьякова?

Оставьте,

я сам

Незнамова не знал...

II mapra 1978

1001

... Yyкоша, кокоша,

и в чем только душа -

мальчишки, девчонки -

все рвутся на пле́чи, все тянутся чуть свет

$\mathrm{K}$ поэзин...

11 мapтa 1978 
Два сна тому назад мне снился дивный сон:

спускалось солнце вниз, садилось за окном, Где, памяти любимого учителя верна. но вот и Вера Дмитриевна сдалась и умерла, а давно ли жили в однокомнатной квартире по Советской улице дробь 102 ?

\section{4 и 30 марта 1978}

1003

... жили-были...

Павел Радимов... Павел Дружинин...

издавались... как же, печатались...

назывались: братья писатели...

Только нет их... ни Павла, ни Павла...

а ведь, помнится, вроде, недавно...

7 апреля 1978

1004

В апреле прилетают жаворонки, взгляну на небо голубое, а по утрам бывают заморозки, глаза и зубы обезболю.

Может быть, я еще в лес похожу, на ежей погляжу, может быть, я еще 20, ну 30 вещиц напишу, чувствую: В жизни моей перелом наступил, хрустнуло; на меня костолом наступил.

8 апреля 1978

1007

Под ногами, спо́ря, то листва, то хвоя.

Ни о чём не помнить, вспомнить и забыть, как листва, как хвоя, быть, или не быть. 
Что я, ненормальный, что ли, сейчас на улицу идти?

Там хиляют охломоны, там зубы чешут бодрецы.

И гоцай мама да бербицуца,

по этой улице вчера

с лицом, застегнутым на все пуговицы, протурили в забой врача.

30 апреля 1978

1009

Да бы́л ли я в городе Фатеж, Курской области?

Убей меня Бог, не помню.

Было, вроде, прямым попаданием, мимо.

Да, мина...

Появилась онкологша.

Мяла - мяла.

Семипалая,

без шипов ходит,

а жжи! - косит.

\section{Перед 67 днём рохдения}

Ну и редкое выдалось утро на диво, и, как в детстве как будто,

жизнь

меня разбудила:

- Солнце всходит - заходит,

а кой тебе годик?

1 февраля 1980 
И слякоть, и скатерть в дорожку, и хвойно, и жалко того, что случится не позже, чем прежде, и, старость, не Храм Громовержцу, а, сказано", срам кромешный.

3 февраля 1980

- Межировым

Как будто я вор,

как будто я что-то украл, какой-то Указ,

какой-то разговор,

был Блок, Иннокентий Анненский, был Пастернак, внезапно очнешься: - ,қогда, когда не в начале“... теперь я хочу только спать, господа, только спать, (5 пишем, 4 вычитаем)...

6 февраля 1980

„Хіба ревуть воли, як ясла повні?"

Но мы и не „ревли“, а молча мёрли,напомнила мне снова двоюродная мова языка родного.

19 февраля 1980

... Не в среду... может быть, во вторник, в субботу, может быть... Не вспомнить... Когда-то, да... Должно быть, вправду, тог да, ког да... Давным - недавно...

20 февраля 1980 
Маска выросла на лице, пахнет сыростью на людей, Повстречаю брата Петра, вопию: - здорово, мордва, повстречаю Павла, не брата.все мы националы, однако...

25 февраля 1980

... День сегодня подмосковный, ничего не вспоминается, плесень не воспламеняется, К ночи снова подморозит, голова ли моя, головушка, до чего ты... да чего уж там!..

29 февраля 1980 (висохосного года)

Молчать не надо. Лучше -

о корме, о капусте,

о стариках, о детях, развлечь их, растормошить ошибка, вы ошиблись! поговорить о жизни.

7 мapтa 1980

Не волынь, угомонись, вели себя похоронить...

... Сердце билось-не-билось, длилось - здравствуй-прощай, а в ушах колотилась эта темно-вишневая шаль...

15 марта 1980 
Боже мой,

За что мне схватиться: - „процай“ или „здравствуй“?

Сегодня то я еще во, ничего.

а завтра?

20 марта 1980

Господи, ад и рай!

Господи, я твой раб!

Разные на земле цветы,

в марте мимоза это ты.

Господи, не погуби, смилуйся!

Господи, погоди...

25 марта 1980

... и неба желтый желатин.

Мужик запомнил, не забыл,

и как кружились зеркала́

В старинном ресторане,

и как встречали вечера,

как ночи ночевали...

14 июня 1980

Боже,

как болят глаза от этих жёлтых листьев,

как хрустит хрусталик!

... Осень, всё разрыто.

26 сентября 1980

Отвоевался, отвоевал, помер Иван, пролетарий всех стран.

27 сентября 1980 
Внуку Илье

Эник, Беник, именинник, видно мне теперь, как сместился центр мира от меня к тебе.

7 марта 1981

Годы текут между пальцами, и повторяется снова ранняя акселерация Маяковского, Третьякова, Хлебникова...

14 мapta 1981

... послушать радио, что-ли, каки́ известия с воли, какая погодка ноне В Лондон-Вядском районе... 15 мapta 1981

Рифмую то, рифмую сё, рифмую Курск и Кинешму, и, наконец, рифмую всё и лично Василь-Василича! 
Пошёл в магазин, купил маргарин.

А там говорят:

- Сам, сам виноват!

Вроде было вёдро, вроде нет.

Тёмно было, только первый снег, Первая любовь, последняя любовь всё забыл, не помнит ничего...

4 апреля 1981

... А главная болезнь -

людобоязнь...

27 мая 1981

Как бывало, войдёшь в тёмный лес, В тёмный лес, под знакомый навес, где малиновка полог сплела, где ползут муравьи по стволам, ой, Боже мой, неохота вертаться домой!

7 нюля 1981

Трави, трави, затворник, твори стихотворенье:

- сегодня понедельник, а завтра воскресенье, а послезавтра вторник...

7 сентября 1981 
Заместо Леонид Фомич бухнул: -

- „не один Фомич".

Тут ему и каюк ему.

29 охтября 1981

И многие, многие другие (и многие совсем другие...)

29 октября 1981

Умолкает ветер.

Вечереет вечер.

Вохруг седого месяца

внучата соберутся,

и присказки засветятся,

молчанки запоются.

10 января 1982

... Когда же заветной могилы

коснулись железо и медь.

- Не надо, - взмолилась Марина, -

не всё ли равно, где висеть...

10 января 1982

Эти на тех, те на этих.

Того и гляди, разнесут землю.

(Упаси, Господи,

месяц с рожками...)

12 января 1982 
... К нам, в Ду́бовку, похожий на Элюара,

каким его изобразил Макс Эрнст на

фронтисписе сборника „Умирать оттого, что не умираешь",

явился Долматовский,

и вот так, вдруг, угодил под бомбёжку.

26 января 1982

... а пошла ты...

со свонм банабаком!...

3 мapra 1982

Какие то слова блукают в воздухе.

Кто-то что-то сказал.

Кто-то сказал: - а иди ты с твонм банабаком.

иди... с твоим банабаком...

пошла ты со свонм банабаком

со свомм банабаком

со свонм банабаком

СО СВОКМ

8 мapta 1982

E. A.

Белла, Белла,

белла синьорина, мне чужую тайну выдали стихи, что она любила,

и была любима, и любя, светила голосом свечи.

15 марта 1982 
Был такой „симонист“ - Лев Ландау.

- Симфонист, пианист? - Да неправда!

Попросите Мигдала, Мигдала,

Он навряд ли откажет, навряд ли!

Вспомяну и "лорда Рёзерфорда“

(дай Бог старым и мудрым здоровья!)

17 марта 1982

Сидел в читальне.

Смотрел газету.

И вдруг припомнил:

приматор Праги“.

И та скупейшая пражанка,

что мне приснилась

однажды дважды.

18 марта 1982

Какие-то минёры,

какие-то сапёры,

какие-то понтоны,

а где они, патроны?

Была у комиссара

еврейская носяра,

и результат известен,

что Вечный Жид - не вечный.

Вариант:

что Вечный Жид бессмертен.

19 мapra 1982 
... и, видит Бог,

оказывается, мы еще не весь свой долг

вернули Родине...

20 мapra 1982

Ветер, какой сильный ветер!

Как запустит, как, следом, залепит...

... A у нас теперь

на носу апрель.

И у них апрель:

целый день капель.

23 мapta 1982

- Бабушка Мозес! - Тишина.

Бабушха Мозес из СШlА:

лучшее украшение кахдой интеллигентной квартиры бабушкины картины.

Бабушха Мозес: „Солнце зашло“"

Да, ну и что же? На ферме светло у бабушки Мозес.

•Название одной из картин.

Эx, тёк, тёк, тёк.

и с порожка - шлёп!

На ковре, на траве, на преклонном четверге пьют сивуху в ресторане наши инопланетяне.

26 мapта 1982 
... и лично товарищ Каменев ...

... и лично товарищ Бухарин ...

... и лично товарищ Рыков ...

Да, ну, как это все не личит

Не лично ...

6 апреля 1982

- Дед, а, дед...

- Чего тебе, баба?

- Да ты не спал бы, дед...

- А, чтоб тебе, баба!

А между тем смеркается

и (чем душа жива:)

в полусне слова

самозарождаются.

29 апреля 1982

Та в Aхтырке, того в Усть-Каменогорске.

Наконец и на младшего пришла бумага.

Скоро, видимо, не останется никого.

Как и этих, Савичевых, из блокадного Ленинграда.

16 апреля 1982

Да, главное слово - последнее слово.

Но первое слово главней второго.

А Бунин хотел (или, может быть, Блок)

Чтоб были стихи из неглавных слов.

2 мaя 1982 


\section{- ЛЕТОПИСЬ ВСЕЙ НАШЕЙ ХИЗНИ *}

\section{O поэзии Яна Сатуновского}

После гибели Маяковского, произошедшей на глазах всей страны, гибель, где сцена - вся страна, словно гладиатор на сиене, началось крушснис слова, гибель культуры, образовалась ситуация провала, бездны небытия. Конечно, эта ситуация была создана искусственно. В тридцатых годах почти никто не знал о „Воронежских тетрадях“ Осипа Мандельштама. В известной мере они были сопряжены с учетом достижсний футуризма при вполне возможном неприятии самого футуризма. В го же время в Петербурге взрывались и горели Даниил Хармс и Александр Введенский, но они были известны лишь узкому кругу друзей. В эти же годы работал замечательный московский поэт Георгий Оболдуев, однако его творчество также практически не было известно, а сам он, в основном, находился в лагерях.

Поэзия, кроме всего прочего, - это развитие средств собственной выразительности, развитие поэтики. Среди поколения поэтов, ушедших на финскую, а затем и отечественную войну, бывших студентов ИФЛИ, так называемых "младоконструктивистов“ уже было ощущение, что слово нужно менять, что без трансформации слова поэзия теряет свою силу. Они чувствовали, что поэтическое слово могло развиваться только при скрещении дос гижений футуризма и конструктивизма. И самым талантливым был среди них Михаил Кульчицкий, но он погиб на войне, как и болышинство поэтов его поколения.

В 60-ые годы так называемые „эстрадные“ поэты использовали, возможно, бессознательно, достижения скрешенных футуризма и конструктивизма. Но в их стихах перекрестились вторичные и третичные признаки тех значительных литературных течений. Они с успехом это демонстрировали и как бы напоминали, что когда-то суцествовало болышое искусство.

А теперь попытаемся определить место Яна Сатуновского в эволюции развития русской поэзии. Как раз именно Сатуновскому удалось наяболее органично и по существу соединить достижения двух течений, о которых говорилось выше. Причем без спекулятивно-демонстративных приемов, которые можно обнаружить у поэтов- „эстрадников“.

А ведь Яков Абрамович (Ян - это псевдоним) писал стихи еще в тридцатые годы. И уже после войны он познакомился и очень подружился с Георгием Оболдуевым. Он очень гордился этой дружбой. И гордился тем, что его ценил поэт, которого он считал очень значительным явлением в русской литературе. И не удивительно, что Оболдуев ценил Сатуновского. Видимо он чувствовал в Якове Абрамовиче продолжателя той новой поэзии, к которой принадлежал и сам.

Кстати, именно Сатуновский настроил меня на то, что я под псевдонимом А.Н. Терезин подготовил сборник стихов Оболдуева и предложил его издать профессору Вольфгангу Казаку. Этот сборник составил сам Георгий Оболдуев. Существовало три экземпляра. Один из них жена поэта Елена Благинина передала на хранение Яну Сатуновскому, тот отдал его Всеволоду Некрасову, а он, в свою очередь, - мне. Сатуновский очень мечтал о том вре- 
мени, когда Георгий Оболдуев станет известным поэтом. К сожалению. этого до сих пор не произошло.

Был еще такой эпизод. Алексей Крученых терпеть не мог современных поэтов, точнее - почти никого из них для него не существовало. Однажды Сатуновский позвонил незнавшему его Крученых, и ничего не объясняя, начал читать свои стихи. Крученых молча слушал. В какой-то монмент Яков Абрамович остановился. „Дальше, читайте дальше,“ - потребовал Крученых. Когда чтение прекратилось, Крученых сказал: „Где вы находитесь? Мой адрес знаете? Сейчас же приезжайте." Пожалуй, это был один из уникальных случаев, когда Крученых признал поэта как своего, идущего от линии Маяковского, Каменского, Хлебникова...

Исторически именно в годы второй мировой войны в реформации поэтического слова должны были произойти очень значительные сдвиги. И они происходили в ряде европейских стран. Лично для меня это хорошо прослсживается на примере польской поэзии, которую я много переводил, издал антологию польской поэзии от Яна Кохановского до наших дней. На примере замечательного польского поэта Тадеуша Ружевича видны резкие перемены фактуры поэтического слова. Произошел переход к свободному стиху, к совершенно новой системе координат. Эго уже иное мышление. Само слово у Ружевича оголяется, отметаются рифмы, метафоры. Слово само по себе приобретает огромную силу.

Казалось бы, и в русской поэзии эти кардинальные изменения должны были произойти. И к этому шли два поэта. Это Борис Слуцкий и Ян Сатуновский. Слуцкий оголяет слово, лищает его поэтизмов. Сатуновский же, на мой взгляд, гораздо многограннее. У него есть та же прямота и оголенность, что и у Слуцкого, но также он идет и с другой, „хлебниковско-крученовской“ стороны, он наслахдается природной данностью русского слова, наслаждается тем, что это слово само по себе прекрасно, что это Богом данная человеку игра.

Но, к сожалению, они не совершили окончательной реформации поэзии. Они ее подготовили, но не завершили. Конечно, очень мешала огромная инерционность, образовавшаяся в русской поэзии. А они сделали очень большое дело. Они довели реформу до критического состояния, но не смогли сделать последнего рывка.

Кстати, поэзия Яна Сатуновского - это своего рода летопись всей нашей жизни. И фиксация примет нашей жизни сделана удивительно живым, чутким словом. Летопись - очень характерная черта поэзии Якова Абрамовича. Кстати, я думаю, что его военные стихи еще послужат в качестве свидетельства того, что же было на самом деле.

И, к великому моему сожалению, Яна Сатуновского, ставшего чуть ли не единственным звеном в цепочке русской поэзии, соединившим собой тридцатые и пятидесятые годы, до сих пор очень плохо знают, как, впрочем, плохо знают и многих других замечательных русских поэтов. Будем надеятся, что настанет время, ког да всем воздастся по их заслугам.

Москва, сентябрь 1993 г.

Геннадий Айги 


\title{
Приложения
}

\section{БИБЛИОГРАФИЯ ПУБЛИКАЦИЙ САТУНОВСКОГО}

\author{
с ссылками на включение автором в рукопись 1979 г. (Ру)
}

и братом в книгу в книгу 1992 г. (X.n.c.)

\section{Автологел Аволловз $-77^{4}$ Публпкацва Мпхапла Шемякпва Парих 1977, стр. 72-73}

Жлоб Муня куккает холо (Х.п.с.) 33 Завернувши в карту мира (Х.n.c.) 86 И та же чертовня (X.n.c.) 76 Летите, голуби, летите (X.n.c.) 80 Мужественно (Pу, X.n.c.) 23

Не Шостакович (X.п.c.) 82

Нет, не смешно 150

Никак не запомню (Ру, Х.п.с.) 87

По радио - военачальники 40

Поговорим с тобой (Х.п.с.) 17

Появилась онкологша (X.п.с.) 296

Представь себе (Рy, X.n.c.) 126

Русские по-турецки (Ру, Х.п.с.) 235

С трудом (Рy, X.n.c.) 110

Смотрюсь в это зеркало (Pу, Х.n.c.) 234

Стою перед дверью (Х.п.с.) 143

Уважаемые дамы и господа 94

Уничтожаю (X.п.с.) 90

Художник Володя Яковлев (X.n.c.) 110

Целый день 235

Юность 140

\section{Aвтологва pycckol nosin日 $\mathbf{X I X}-\mathbf{X X}$ мex \\ Публпкация Алексавдра Петрова \\ Београд 1977, стр. 365-373}

Андрей Платонов (Ру, Х.л.с.) 139

Бабель (Рукописи его...) (Ру) 226

Благопристойный 230

Всё законы (Pу, Х.n.c.) 96

Захлопнулась калитка (Ру) 14

Сегодня 17-ое июня (Х.п.c.) 111

Симанович-старик (X.n.c.) 229

Ха и Bg (Py, X.n.c.) 222

\section{Хургал „Левпафав“, 1979.2 Публпкадия Мшханла Гробмава Нерусалши}

В чём 120

Воняло, вопило 239

ДЕбет - кредит - оборот 83
Жлоб Муня ку́кает коло (X.п.c.) 33

Завернувши в харту мира (X.п.c.) 86

И та же чертовия (X.п.c.) 76

Летите, голуби, летите (X.n.c.) 80

Мужественно (Ру, Х.п.с.) 23

Не Шостакович (X.n.c.) 82

Нет, Марцинковский (Ру, Х.п.с.) 113

Нет, не смешно 150

Никак не запомню (Py, X.n.c.) 87

Ну, вот и дорбга 99

По радио - военачальники 40

Поговорим с тобой (X.n.c.) 17

Появилась онкологша (X.п.c.) 296

Представь се6е (Ру, Х.п.с.) 126

Протягиваю руку (Ру, Х.п.с.) 61

Русские по-турецки (Ру, X.n.c.) 235

С трудом (Ру, Х.п.c.) 110

Смотрюсь в это зеркало (Ру, Х.п.с.) 234

Стою перед дверью (X.n.c.) 143

Уважаемые дамы и господа 94

Уничтожаю (X.n.c.) 90

Христианин (X.n.c.) 99

Художник Володя Яковлев (Х.n.c.) 110

Целый день 235

Что-то знакомое (Рy, X.n.c.) 127

Юность 140

Ялта (Х.п.с.) 235

\section{Aвтологев}

воsethet pycckol noasm

Голубов лагувч. 1.1980, стр. 325-327

Публпкадша Ковст. Кузичввского

- Грпropma Konariea

Ньютоввшлл, Масc.

В чём 120

Дебет-кредит-оборот 83

Ж лоб Муня күхает холо (Х.п.с.) 33

Завернувши в харту мнра (X.n.c.) 86

Летите, голуби, летите (X.n.c.) 80

Не Шостакович (X.п.c.) 82

Ну, вот и дорбга 99

Поговорим с тобой (X.п.с.) 17

Представь се6е (Py, X.n.c.) 126

Протягиваю руку (Рy, X.n.c.) 61

Уважаемые дамы и господа 94

Хрнстианин (X.n.c.) 99 
Художник Володя Яховлев (Х.п.с.) 110 Что-то знакомое (Ру, Х.n.c.) 127

Ялта (Х.п.с.) 235

Газета "Московские Комсомолец" 15.2.1987, стр. 4

Публикацпл С. Бучкова Mocxea

A всё-таки (X.n.c.) 109

Бессмыслица, двусмыслица 140

Бывает стих говорной 119

В магазине (Py, Х.n.c.) 131

В полночь (Ру, Х.n.c.) 111

В чём 120

Выскажу вам (Pу, Х.п.c.) 108

Олицетворённая 135

Стихи! Стихи! 123

У всех знахомых 116

Утром солнце (Ру, Х.п.c.) 141

\section{Переводи ва вемедкй пзик}

Публпкация Вольфгана Казака Цюр 1989

Бабель (Рукописи его...) (Ру) 226

Ваньке дали 8 лет! 88

Летите, голуби, летите (Х.п.c.) 80

... ну прощай покедова 64

Пусть победить слабейший (Ру) 300

\section{Хурала „10ность“ 1989.4, стр. 94-95 \\ Публпкацпи Владпмпра Глоцера Mockea}

А у вас - кока-кола 164

Бурные, долгие (X.n.c.) 98

В век (X.n.c.) 32

В захрытой лаборатории 124

В некотором царстве (Ру, Х.п.с.) 65

Верли6р (Х.п.с.) 65

Выскажу вам (Py, X.n.c.) 108

Здесь, на площади? (X.n.c.) 79

И хоть слушаешь (X.n.c.) 125

Коль скоро (Ру) 91

Огни над окнами (X.n.c.) 98

Пришёл хо мне (РУ, Х.п.с.) 95

Разучившись мыслить (Ру, Х.п.с.) 130

Слушай сказку, детка (X.n.c.) 97

У Истории 65

У меня - отличное (Х.П.с.) 152

Хочу ли я посмертной (Ру, Х.n.c.) 101

\section{Хурнал „Новнё мпр" \\ 1990.2, стр. 108-112 \\ Ппблпкация В ладимпра Глоцера Mockea}

Aх, как пахнет (Ру, Х.п.с.) 182

Весна, весна! - лопоча 13

Вчера, опаздывая (Ру, Х.п.с.) 95

Кто помнил (Рy, Х.n.c.) 131

Март меня не радует 205

Нет никого на свете (Py, X.n.c.) 203

Пустые стоят коровники (X.n.c.) 187

Человек, которого я обидел (Ру) 170

Чудной денёх! 109

Чужая, чужая, чужая (X.n.c.) 185

Эта видимость смысла (Ру, Х.п.c.) 220

Эо немыслимо (X.n.c.) 50

Я теперь работаю (Ру, Х.п.с.) 104

Я хорошо, я плохо жил (Х.n.c.) 99

\section{Хурнал „Orоввх \\ 1990.25, стр. 8 \\ Публпкация Наталпп Загальской Mocrea}

Рабин: бараки, сараи (Х.п.c.) 23

Хуравл „Октябрь“

1991.7, стр. 110-113

Публихацпл Петра Сатуновского Mocxea

Достану томик (X.n.c.) 190

За комиссиями (X.n.c.) 234

Капитан Чернов 75

Мутный день (X.п.c.) 287

Не говорите мне (X.n.c.) 77

Одни говорят (X.n.c.) 251

Остосвинел язык (РУ, Х.п.с.) 135

Oх, и пополито нашей кровушки 158

По радио - военачальники 40

Поэзия гиблое дело 28

Cашка Попов (X.n.c.) 163

Свонм потайным фонариком 186

Спросите их, спросите (X.п.с.) 176

Ты, вечно хныкающий 32

Я был из тех (X.n.c.)

Я не хочу воевать 175 
Абай Кунанбаев 44

Айги, Геннадий $61,64,90,217,246,248$

Аксаков, Иван 62

Амбарцумян, Виктор 82

Анненский, Иннокентий $127,278,279$, 280,297

Антокольский, Павел 289

Аронов, Саша 257

Арцимович, Лев 82

Асадов, Здуард 257

Ахмадулина, Белла 303

Ахматова, Анна $32,287,290$

Бабель, Исаак 97, 129, 225, 226, 242

Барто, Агния 253

Басилова, Аленка 145

Белый, Андрей 250

Берия, Лаврентий 77,124

Блок, Александр 50, 200, 228, 297, 306

Бродский, Носиф $64,119,142$

Бунин, Иван 185, 306

Бурич, Владимир 90, 216, 233

Бурлюк, Давид 217

Бурлюк, Николай 217

Бурлюк, Владимир 217

Буслаевич, Виктор 24

Бухарин, Николай 131, 184, 306

Вагинов, Константин 221

Введенский, Александр 148, 220

Вегин, Пётр 253

Вознесенский, Андрей 191

Герцен, Александр 33

Гинзбург, Александр 20, 144

Глоцер, Владимир 18

Гоголь, Николай 33,188

Гозенпуд, Абрам 46

Горбовский, Глеб 119

Грин, Aлександар 232,280

Гробман, Миханл 217

Громыко, Андрей 223

Губельман, Момсей 168

Губергрица, Марика 73

Гумилёв, Николай 93

Димитров, Георги 283

Долматовский, Евгений 303

Достоевский, Фёдор 60,274
Дри 3, Овсей $84,93,142,143,234,284$

Есенин, Сергей 187, 276

Заболоцкий, Николай 251

Зальцман, Леонид 146

Заходер, Борис 264

Зданевич, Илья 237,241

Злотников, Натан $119,251,254$

Зоргенфрей, Вильгельм 50

Зочјенко, Михаил 68, 98, 129

Ивинская, Ольга 293

Ильф, Илья 74

Исаковский, Михаил 40

Каверия, Вениамия 150

Казакевич, Зммануил 13

Каменев, Лев 131, 306

Кандинский, Василий 143

Кипиани, Давид (футболист) 272

Кирсанов, Семён 254

Кожевников, Вадим 249

Корнейчук, Александр 61

Корнилов, Владимир 253

Кочетов, Всеволод 61, 92

Кречетов, Сергей 92

Кручёных, Алексей 18

Кузмин, Михаил 275

Кулешова, Роза 235

Куняев, Станислав 285

Куперман, Исер 126, 243

Кушнер, Александр 230,255

Ландау, Лев 304

Левитан, Исаак 36

Лейбсон, Владимир 238

Лемешев, Сергей 42

Ленин, Владимир 180

Лившиц, Венедикт 242

Магомаев, Муслим 263

Малевич, Казимир 237

Мандельштам, Осип $18,67,209,242$. 254

Мариенгоф, Анатолий 24, 55

Маркиш, Давид 91

Марков, Алексей 92

Марков, Георгий 92 
Матусовский, Миханл 89

Маяковский, Владимир $42,92,94,122$, $211,279,300$

Меерович, Иосиф 15

Межиров, Александр 249,297

Мейерхольд, Всеволод 97

Мемека 64

Мехлис, Лев 112

Мигдал, Аркадий 304

Микей, Александр 76

Михоэлс, Соломон 91, 251

Мишин, Василий 250

Мовчан, Павел 293

Мошкин, Александр 89

Мошковская, Змма 51

Нарбут, Владимир 50

Некрасов, Всеволод 17, 85, 133, 228

Оболдуев, Георгий 135

Окуджава, Булат 189

Пастернак, Борис $17,29,83,122,199$, $200,269,293,297$

Передреев, Анатолий 119

Петров, Евгений 74

Пильняк, Борис 125

Платонов, Андрей 31, 129, 139

Плисецкая, Мая 152

Плучек, Валентин 152

Подолинский, Андрей 119

Полищук, Ян 61

Попов, Александр 163, 283

Поповкин, Евгений 130

Пришвин, Михакл 148

Прокофьев, Areксанда 142

Пулькин, Иван 119,257

Пушкин, Александр 33, 60, 136, 180 , 205, 230

Рабин, Оскар 23, 217

Радек, Карл 184

Радимов, Павел 295

Рахманинов, Сергеи 282

Рубина 64

Рыков, Aлexсей 131, 306

Савичева, Таня 306

Самойлов, Давид 76, 253

Сапгир, Генрих 26, 116, 142, 260

Сапожников, Евгений 146

Сахаров, Андрей 34,82

Северянин, Игорь 112

Сельвинский, Нлья 122, 267

Синявский, Андрей 242
Слуцкий, Борнс 26, 142, 185

Случевский, Константин 185

Солженицын, Аrександр $24,34,242$, 251

Соловьёв, Владимир 291

Сологуб, Фёдор 185

Софронов, Анатолий 92

Сталин, Носиф 18, 77, 180

Стравинский, Игорь 143

Сутин, Ханм 14, 91, 132, 178

Татлин, Владимир 198

Терентьев, Игорь 237

Тихонов, Николай 122

Толстой, Алексей К. 33

Толстой, Алексей Н. 33

Толстой, Лев Н. $33,55,60$

Третьяков, Сергей 294, 300

Троцкий, Лев 18

Туманский, Василий 119

Тухачевский, Миханл 275

Тютчев, Фёдор 87, 185

Фадеев, Александр 168

Фет, Афанасий $92,135,185,265,281$

Фефер, Ицик 220

Фофанов, Константин 224

Хайам, Омар 213

Хармс, Даниил 148, 220, 222

Хачатурян, Арам 82

Хвильовый, Микола 125

Хелемский, Яков 89

Хлебников, Велимир $55,190,198,300$

Холин, Игорь 34, 61, 70, 72, 85, 95, $148,231,253$

Хрущев, Никита 145, 180

Цветаева, Марина 51, 278, 302

Чехов, Антон 55

Чукалин, Иван 250

Чуковский, Корней 252

Чухонщев, Олег 251

Шаламов, Варлам 21, 272

Шевченко, Тарас 188

Шершеневич, Вадим 237

Шехтер, Марк 282

Шкловский, Виктор 150, 262, 289

Шкуро, Андрей 250

Шостакович, Дмитрий 82

Яковлев, Владимир 110

Яковлева, Надежда 262 
Apollinaire, Guillaume 213

Balzac, Honoré de 256

Bardot, Brigitte 206

Beckett, Samuel 225

Bergson, Henri 270

Braque, Georges 176, 179

Brecht, Berthold 53

Carroll, Lewis 264

Cellini, Benvenuto 21

Chopin, Frédéric 277

Corneille, Pierre 281

Eichmann, Adolf 92

Eluard, Paul 303

Emst, Max 303

Fichte, Immanuel 126

Flaubert, Gustave 34

Freud, Sigmund 51, 204

Gogh, Vincent van 280

Gomulka, Whadysław 81

Hikmet, Nazim 186, 276

Hitler, Adolf 44, 69, 165, 203

Kant, Immanuel 270

Lavoisier, Antoine 270

Léger, Marie-René-Alexis 176, 179

Liebknecht, Karl 57

Liszt, Franz von 280

Lollobrigida, Gina 76, 106

London, Jack 183

Luxemburg, Rosa 57

Marx, Karl 77, 164, 283

Matisse, Henri 199

Maurois, André 38

Mendelssohn Bartholdy, Felix 280

Monroe, Marilyn 76, 198, 248

Multatuli 53

Nasser, Gamal Abd el 118

Nehru, Jawaharlal 118

Nietzsche, Friedrich 126

Norodom Sihanuk 118

Picasso, Pablo 176

Rimbaud, Arthur 249
Sadat, Muhammad Anwar As 257

Shakespeare, William 269

Tizian 248

U Nu 118

Vasari, Giorgio 21

Verlaine, Paul 213

Verne, Jules 219

Villon, François 213

Zadkine, Ossip 110 
How

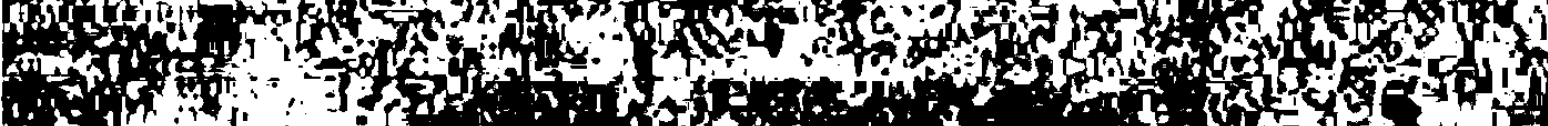

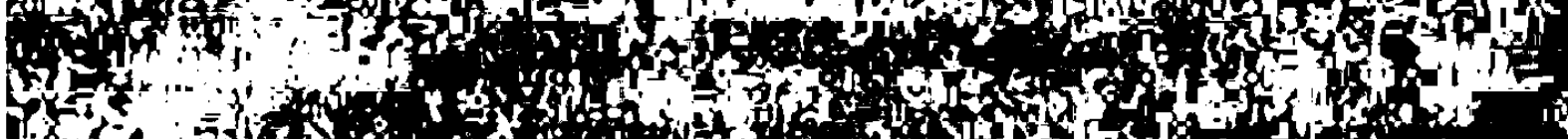

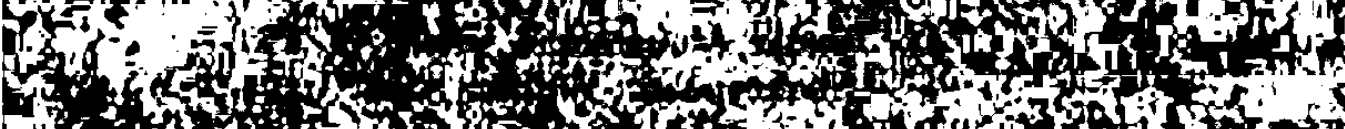

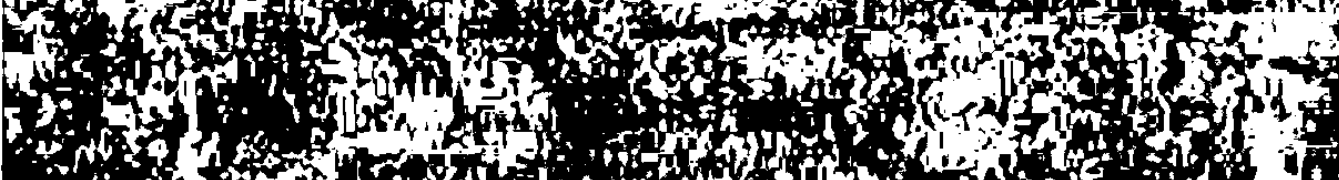

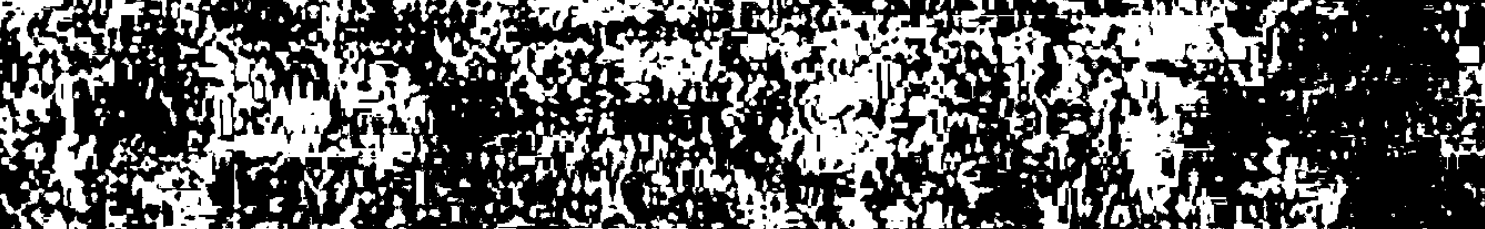

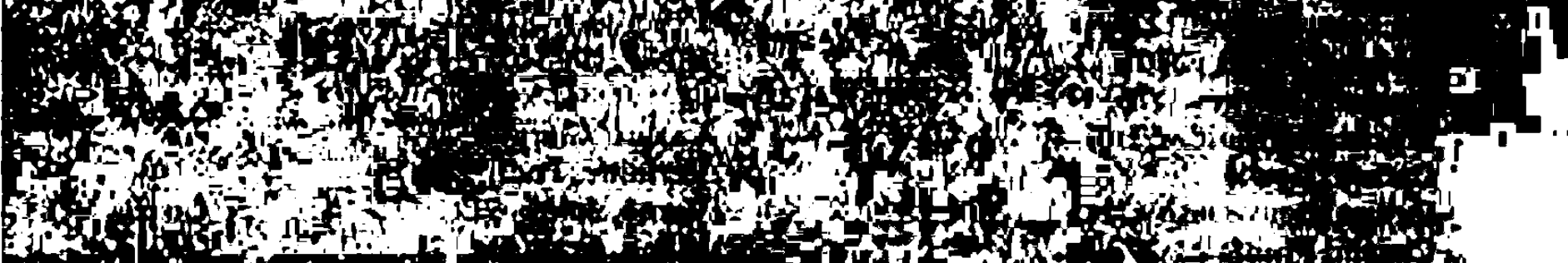

(1)

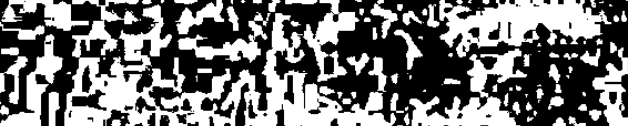

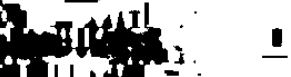
St:

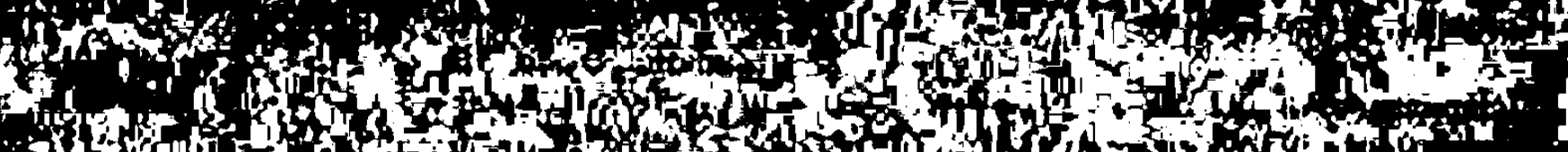

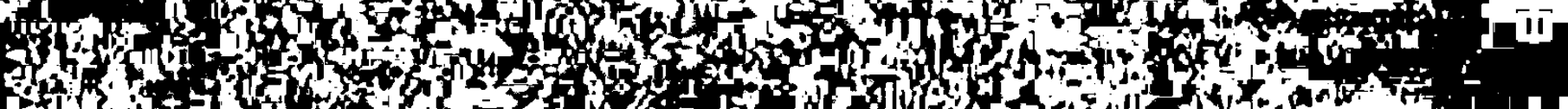

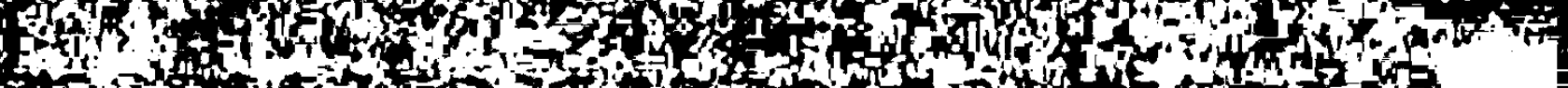

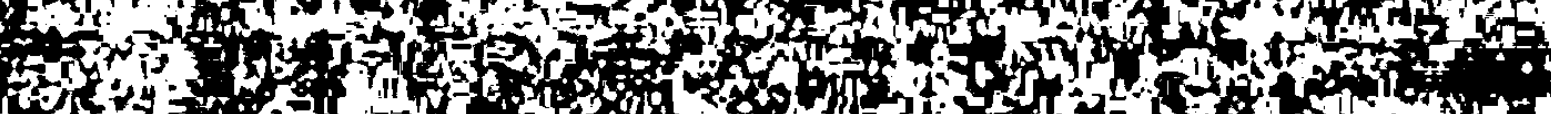

1.5y

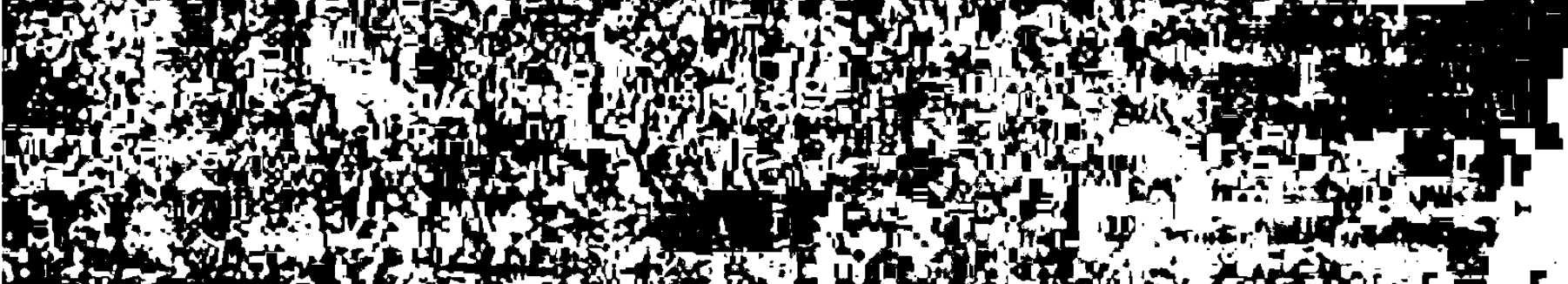
P.

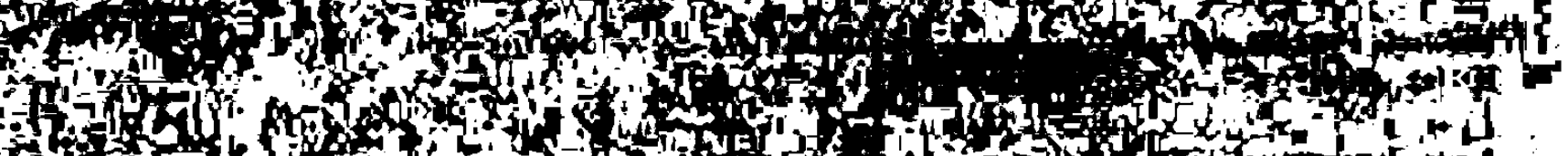

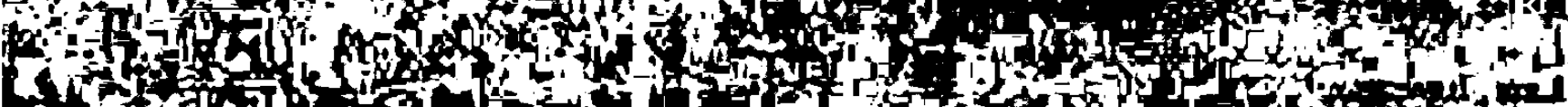

If

(f)

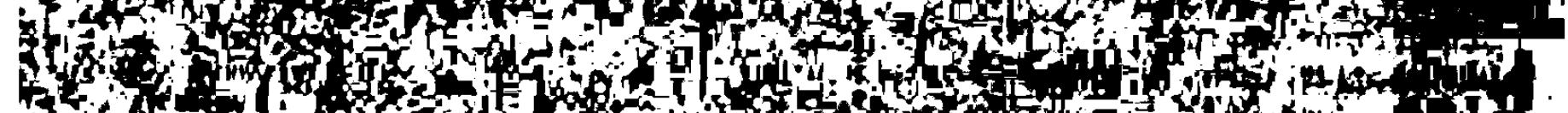

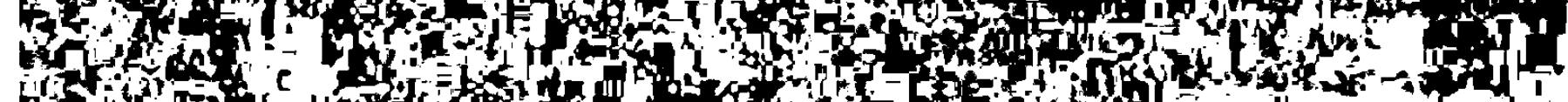

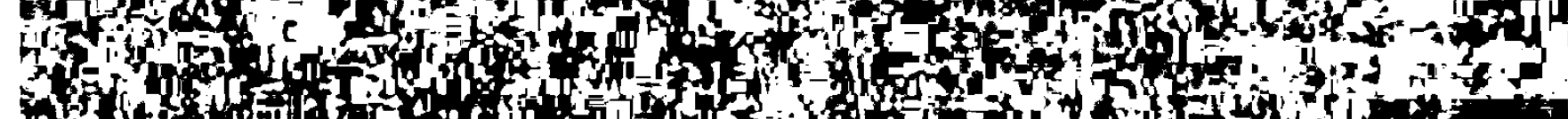

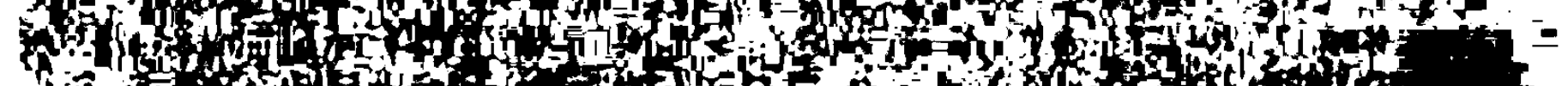

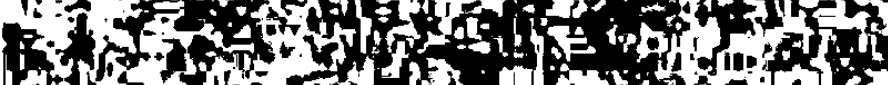
Fon

ofor

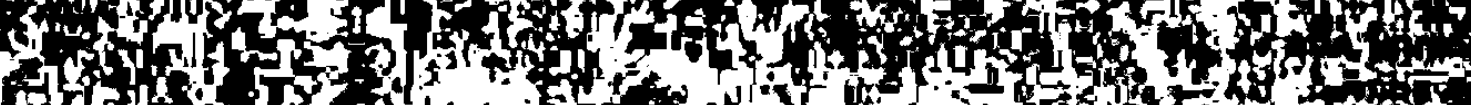

Fon

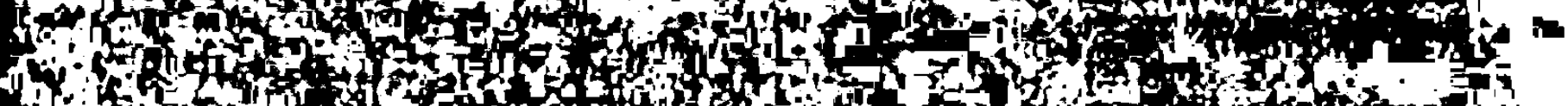

1.

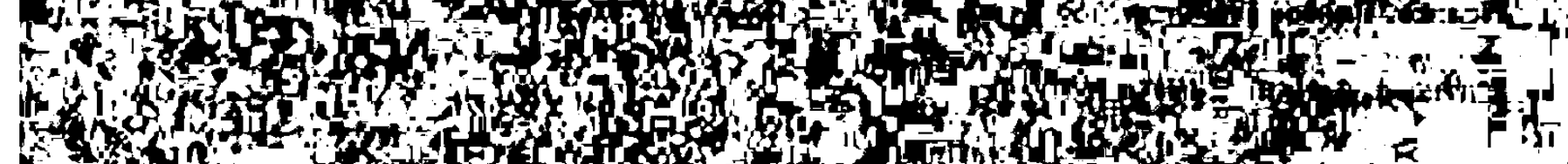

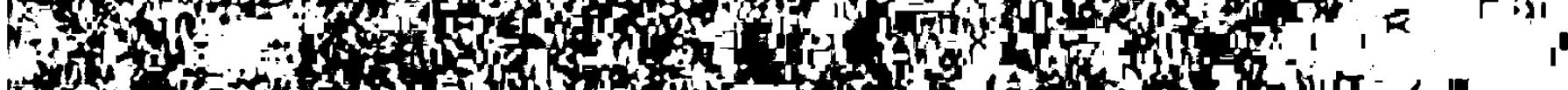

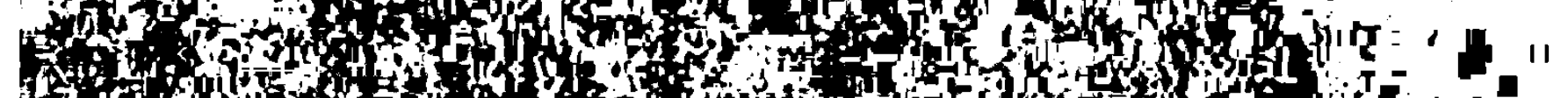

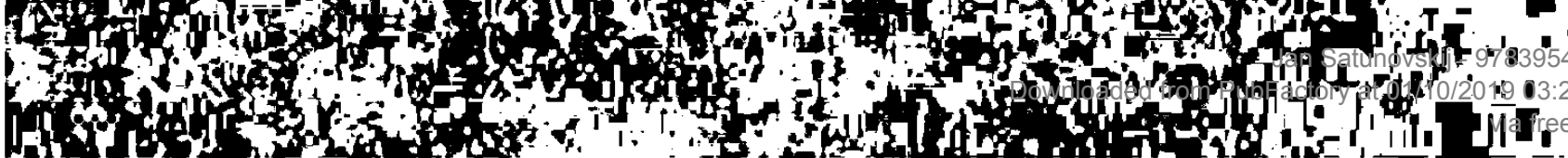




\section{PEECTP ПEPBЫX CTPOK}

O сокращениях см. предисловие на странице 8 .

Стрелка в реесте указывает на стихотворение, за хоторым в источнике следовало перемещенное издателем стихотворение.

а, в сущности, ничего не надо 273

... а впрочем (X.n.c.) 67

А всё-таки (Х.л.c.) 109

A где ты жил 241

А главная болезнь 301

А жив ли Чукалин 250

А Золушка после бала (Х.п.с.) 262

А кому - на, на (X.л.с.) 125

А, может быть, мерило (Х.л.с.) 232

А на улице весна (X.л.c.) 115

А недавно в японской Америке 229

А ну, катись, а ну, вались (Ру) 273

А ну, кому там вздумалось 228

А ну, толкни меня (Ру) 82

А покамест работа мысли (Х.п.с.) 90)

... а, помнится (РУ, Х.л.с.) 253

... а пошла ты 303

А у вас - кока-кола 164

... а у нас сетодня клев 268

... а укра́ницы 106

А чего сто́ит 233

А я прочёл у Белого (X.n.c.) 250

Автопортрет 251

Адепт человеколюбия (Х.n.c.) 239

Акация моя, акация! (Х.л.с.) 284

Андрей Платонов (РУ, Х.п.с.) 139

Анна Войцык (Х.п.с.) 141

Антисемит (X.л.с.) 255

Антисоветизм 74

Архангелы-евреи ( $\rightarrow 710$ ) (Х.л.с.) 142

Acb? 204

Ах, в мини-ю6очке! 269

Aх, как пахнет (Ру, X.n.c.) 182

Ах, какой гул и треск $(\rightarrow 410) 36$

Аэрарии, дендрарии, Ривьера 55

Бабель (Всё убито...) (Ру, Х.п.с.) 225

Бабель (Рукописи его...) (Ру) 226

Бабка подымается бодрая (Х.п.с.) 53

Бабушка Мозес! - Тишина 305

Безимянный ( $\rightarrow$ Шёл, нашёл...) 71

Бей своих, чтоб чужие боялись! 15

Бейте поэта, бейте, гады 209

Беленький (Х.л.с.) 18

Белла, Белла 303

Берегись поезда $(\rightarrow 54)$ (Ру, Х.п.с.) 15

Бессмыслица, двусмыслица 140

Битых 171
Благопристойный 230

Благословенно $(\rightarrow 562)$ (X.I1.с.) 121

Боже, / как болят глаза 299

Боже, как орут старики! 289

Боже мой 299

Борис Абрамович Слущкий (Х.п.с.) 185

Борис Пастернак (X.n.c.) 29

Братцы, что вы о6о мнс знаетс? 78

Брижитка! Бардотка! 206

Брючки - в дудочку (Рy, X.n.c.) 199

Будь готов! (Ру, Х.п.с.) 291

Бурные, долгие $(\rightarrow 663)$ (X.n.c.) 98

Бывает стих говорной 119

Бывают / чудесные дни 214

Бывают художественные сны 240

Был такой „симонист“ 304

Был и на похоронах (X.n.c.) 24

Было, / н осталось (Ру, Х.І1.с.) 207

В апреле / земля (Py, X.n.c.) 101

В апреле прилетают (Рy, Х.n.c.) 295

В век (X.n.c.) 32

В Волокаламском скопе 221

В воскресенье 107

В двусветном воздухе (Ру, Х.n.c.) 279

В день, - моего племянника 86

В „Доме Грина“? (X.п.c.) 280

В заключение (Х.л.с.) 233

В закрытой лаборагории 124

В инфекционном корпусе 231

В книжном магазине 252

В магазине $(\rightarrow 591)$ (Ру, Х.л.с.) 131

В молодости 42

В некотором царстве (Ру, Х.п.с.) 65

В общежитин переплетаются 266

В отвыкией бить жидов стране 43

В Париже $(\rightarrow 623) 110$

В подлом (Pу, X.п.c.) 161

В полночь (Ру, Х.п.с.) 111

В пропыленных бронхах 228

В Рязани 114

... В то утро 81

В утреннюю каламуть (Ру, Х.п.с.) 268

В чём 120

В черно-белом городе 206

В этом городе (Ру, Х.л.с.) 246

В Ялте - отличная флора 234

В Яской Поляне могила ТолстоІ о 55 
Ваньке дали 8 лет! 88

Ваньке дали двадцать лет! 119

Вдруг в памяти мелькнуло 283

Великий Зощенко (Py, X.n.c.) 68

Вера - в терапию 74

Верли6р (X.n.c.) 65

Верю народу (Py, X.n.c.) 27

Весело, звонко (Ру) 〈ср. 267, 274〉 274

Весело, звонко 〈ср. 267, 274〉 274

Весна, весна! - лопоча 13

Весна / проснулась! 215

Becb ropod (Py, X.n.c.) 269

Ветер, какой сильный ветер! 305

Вечер был (Ру, Х.л.c.) 93

Вечер, похожий на Сашу Аронова 257

Взрывом Эдуарду Асадову 257

Владька 121

Вместо сока из томата 93

Во всех анкетах 165

... Во имя Отца и Сына 209

Возле клуба имени Карла Маркса 283

Волны вальса 172

Воняло, вопило 239

... восхресенье, понедельник 261

... воскресенье, понедельник 262

Вот и вышла (X.n.c.) 109

Вот / и месяц прошёл $(\rightarrow 20) 111$

Вот идиотство! 294

Вот хабы да не водка бы $(\rightarrow 757) 55$

Вот как - Плучек еврей! 152

Вот кому я 275

Вот хролик - мирный 248

Вот - мотнуло (X.n.c.) 283

Вот мы сидим (X.n.c.) 208

Вот Ольга (Py, Х.n.c.) 292

Вот он, тот дом (Рy, X.n.c.) 107

Вот уже $(\rightarrow 48)$ (Py, X.n.c.) 151

Вот Чуковский перед нами 252

Время 207

Вроде бы на днях (X.n.c.) 146

Вроде Володи 208

Bсе в капроновых болоньях (Ру) 117

Всё в порядке (Рy, X.n.c.) 254

Всё выговаривается (X.n.c.) 136

Bсе думают одно и то же (X.n.c.) 104

Bce есть: супруга, сервант 261

Всё законы (Ру, Х.п.c.) 96

Все заминки, заминки 250

Все мы люди 118

Все мы смертны (X.n.c.) 75

Всё надоело (Pу, X.п.c.) 62

Всё начальники (X.n.c.) 117

Bсе пишут большие поэмы 85

Всё реже пью (X.n.c.) 76

Всё убито тишиной (Ру, Х.п.с.) 225
Всё, что было - прошло 40

Всё, что кажется так важно 99

Все, что неправда - зачеркни 232

Всё, / что я кричу про тебя 237

Всё шутки шучу ( $\rightarrow$ Я умираю) 72

Всё это 79

Bсегда сомной беда, всегда 164

Bcero ничего $(\rightarrow 760) 61$

Вспомнил, на кого (Ру, Х.п.c.) 196

... вспомнились (Ру, Х.п.с.) 253

Вспомнился Кохтебель 293

Вспомним нашего деда (X.n.c.) 247

Встретил Остапа Бендера 74

Второй месяц 206

Вчера, опаздывая $(\rightarrow 98)$ (Py, X.n.c.) 95

Вчера я оाять написал (X.n.c.) 103

Вы бродите по берегу 176

Вы ошибаетесь $(\rightarrow 428) 92$

Вы при часиках, при сумочке 148

Выдача (Ру, X.n.c.) 278

Выйдем на улицу Осипенко 289

Выскажу вам $(\rightarrow 792)$ (Py, X.n.c.) 108

Вышли трое (X.n.c.) 195

Гаспаров перевёл (X.n.c.) 272

Гена 108

... гиперболы (Ру, Х.п.с.) 108

Главное иметь (Py, X.n.c.) 280

Главное - это (Рy) 151

Главный инженер 183

Глаза 35

Глазами - глазеть 229

Говорил Андрей Андрею 261

Говорила Марина-царица (X.n.c.) 278

Говорит Москва (Ру) 98

Говорят, захонно (РУ, Х.л.с.) 261

Говорят, / и капли (Ру, Х.п.с.) 190

Годовалая бледная (Рy, Х.n.c.) 280

Годы текут между пальцами 300

Голод не довод 243

Город говорунов (X.n.c.) 215

Город играет на гитаре (X.n.c.) 176

Господи, ад и рай! 299

Господи, хахая ночь! (X.n.c.) 288

Гражданин начальник (X.n.c.) 21

Гривеник уронишь 188

Гришка Беркович 144

Гром среди ясного неба $(\rightarrow 578) 69$

Громыко сказал (X.n.c.) 223

Да 6ал ли я в городе Фатеж (Ру) 296

... да, видит Бог (X.n.c.) 289

Да, Вы пишете очень прелестно 28

Да, главное слово 306

Да, поэзия синтахсис (Pу, Х.п.с.) 278 
Да, сны доказывают (X.n.c.) 264

Давайте, братцы (Рy, X.II.c.) 127

Даже ночью светились (РУ, Х.п.с.) 1.39

Далеко от (Ру, Х.Il.c.) 192

Далёкое - 6лизкое (X.n.c.) 81

Два сна тому назад (Py, X.n.c.) 295

Два человека 238

Две / дворничихи (Ру) 16

Двуединый $(\rightarrow 608)$ (X.n.c.) 82

Дебет - кре́дит - оборот $(\rightarrow 723) 83$

Девушки (Х.п.с.) 48

19-ое декабря 260)

Девять двенадцать $(\rightarrow 156) 90$

Дед, а, дед 306

Дед, не говори (X.n.c.) 218

День рождения (X.п.с.) 115

День сегодня подмосковный 298

Деревьями ( $\rightarrow 70)$ (Ру, X.n.c.) 133

Дёрнуло - вперёд, назад 39

Детство, отрочество, война 273

Дико, как „портфель" (Ру) 214

Для меня (X.п.с.) 132

До чего мне нравятся (X.n.c.) 184

Добрый вечер (Ру, Х.п.с.) 38

Дом мод: моддбм (Ру, Х.п.с.) 95

Дома всё в порядке (Рy, Х.и.c.) 149

Д6ма-не-дбма (Ру, Х.л.с.) 289

Дорогой Матусовский! (Ру, Х.п.c.) 89

Достану томик (X.п.с.) 190

Друг у друга кольца крали (Ру) 272

Друзья мон (Ру, Х.п.с.) 83

Думаете (X.n.c.) 76

Думал ли я (Ру, Х.п.c.) 84

Думаю о6 Амеркке 198

Дык ... Тык, пык, мык (X.n.c.) 59

Eва (Py, X.n.c.) 196

Ёжки - миёжки $(\rightarrow 37)$ (Ру, Х.п.с.) 114

Ел филе (X.n.c.) 244

Ёлки-палки (X.n.c.) 143

Ему с фамилией легко 250

Если в стихотворении (X.n.c.) 189

Если думать только о себе 60

Если жизнь - мираж (X.n.c.) 262

Если нет 189

Ещё вращается Земля 30

Женщина, сытая любовью 188

Живу в подмосковной (Ру, Х.n.c.) 195

Живу по старинке (X.n.c.) 62

Жизнь - трансформируется 274

Жил в Ростове $(\rightarrow 315)$ (X.n.c.) 100 ... хили-были 295

Жили были два ауа (Ру, Х.п.c.) 38

„Жирафы в Африке пасутся" 259
Жить!- Не для стариков 163

Жлоб Муня ку́кает коло (Х.п.с.) 33

За 20 лет (X.n.c.) 96

За хомиссиями (X.n.c.) 234

Забываю, куда пошёл (Ру, Х.І1.c.) 193

Завсрнувыши в карту мира (X.n.c.) 86

Завод, завод, н6о завётся 79

Заговаривал зубы (Х.п.с.) 30

Занндевев 286

Займусь-ка я мирмекологией 41

Заместо Леонид Фомич бухнул 302

Замечако много нового 268

Запускали в космос (Py, Х.п.c.) 220

Засыпьте как 6ыло 20

Затмись, светило (X.n.c.) 191

Захлопнулась калитка (Ру) 14

... захотелось-БЫТЬ! 269

Захотелось всякой всячины 113

Зацепился (X.п.с.) 39

... зашили как футбольный мяч 146

Здесь, / бельма выкатив (Х.п.с.) 80)

Здесь были поля полосаты 192

3десь, на площади? ( $\rightarrow 53)$ (X.n.c.) 79

Здесь - / пчёлки (Ру) 149

3лесь расстреляли (Ру, X.n.c.) 248

Здравствуйте (X.n.c.) 285

Зинке Саввиной не дали 194

... знахомая фамилия ... Поляни 142

Знакомое лищо... Анвар Садат 257

Знаменитый Сказочник 108

Знаю, что люди - звери (X.n.c.) 230

Зыки да рыки $(\rightarrow 228) 81$

... и было так чисто 〈ср. 274〉 267

и варьете Драхновски... (Ру) 235

... и, видиг Бог 305

Н вот - Зима 242

И дело не в том, что с годами (Ру) 179

И как она не щерится 57

И, ках с похмелья (Ру, Х.n.c.) 17

И красный не красный (X.n.c.) 75

... и лично товарищ Каменев 306

$\ldots$-..и ложечкой $(\rightarrow 715)$ (Х.н.с.) 120

... и многие, многие аругие 275

И многие, многие другие 302

И Мозикин 89

... и неба желтый желатин 249

И ни в сказке сказать 56

И слякоть, и скатерть в дорожку 297

И счастье улыбнулось! Кто бы 136

И та же чертовня (X.n.c.) 76

И хоть слушаешь (X.n.c.) 125

И чем плотней (Py, X.n.c.) 121

Из Анненского (X.n.c.) 279 
Нз друзей у меня остались 280

Нз поэмы / Вы при часиках 148

Из поэмы / ... я уважаю (X.n.c.) 249

Из цикла „Новые бараки" 261

Из цикла „Старая..." (X.n.c.) 208

Изнемочь (X.n.c.) 279

... из-под полы, из хофты 244

Илюішке девять дней (Х.п.c.) 218

Илюшке иятнадџатый день 217

Илюшке сегодня (Ру) 217

Илюотке три дня $(\rightarrow 484) \quad 112$

Илюшкины дела (X.n.c.) 218

Илья Сельвинский, мастер 267

Иля, скажи: бабка-кацапка. 219

Им говорят, а они молчат 49

Иннокентий Анненский (X.n.c.) 127

Интеллигентный человек (X.I.c.) 147

Интенсивно (Py, X.n.c.) 102

Искать такси (X.II.c.) 254

Исследуйте меня (Ру, Х.п.с.) 85

Ишь, uцучье веко (Ру, Х.n.c.) 123

K нам, в Дубовку 303

К чёрту 242

Казённые вещи (Ру) 182

Как будто всеми (Ру, Х.п.c.) 26

Как будто я вор 297

Как бывало, войдёшь 301

Как вспугнутая стая $(\rightarrow 620) 31$

Как дали (Ру, Х.п.с.) 63

Как его только (Х.п.c.) 275

Как же это так случилось 46

Ках кто, а я (X.n.c.) 258

Как оживляешься (Х.п.c.) 115

Ках прохлада в летний день 290

Как русский, любящий 214

Как сказать: „су́дно“ 34

Ках солнечные иятна 276

Как странно (X.n.c.) 119

Kax тá nрофессорская (Py, X.n.c.) 227

Ках твоя фамилия? 150

Ках у нас в соцгороде 164

Как это вам приходят (Ру, X.п.с.) 282

Как я живу? (Х.п.с.) 162

Как я им должен быть (Ру, Х.п.с.) 43

Как я их всех люблю (Ру, Х.п.c.) 156

Ках я познахомился с Айги $(\rightarrow 156) 90$

Как / я устал! 25

Кахая мне разница (X.n.c.) 59

Какая тишина (X.n.c.) 19

Какая-то женщина (X.n.c.) 263

Какие-то минёры 304

Какие-то слова блукают 303

... какого 294

Какбе крестьянство?! (X.n.c.) 58
Какой он ветреный, март 181

Какой-то закат (Py, X.n.c.) 105

Каменные 6абы 110

Капитан Чернов 75

Картина с таким скжетом (Ру) 201

Каштганы фонарей (Ру) 235

Клянусь 225

Когда же заветной могилы 302

... хогда ирншли забирать 259

Когда я перечнтываю эти стихи 264

Когла я стал лысеть 270

Кого она любит чнтать? (Х.п.с.) 219

...колебания (Py, X.п.c.) 250

Колокольчики звенят (X.n.c.) 290

Коль скоро (Ру) 91

... комендант наук (X.n.c.) 106

Кончается наша $(\rightarrow 608)$ (X.n.c.) 91

Кончнлись морозы (X.п.c.) 133

Копейкин - хапитан 52

... коричневые губы (X.n.c.) 200

Коробка скоростей $(\rightarrow 566)$ (Ру) 87

Коррупция, корпорация 38

Космонавтика - наука 271

Который год (X.n.c.) 89

Красивая девочка 246

Красок нет 193

Кричи не хричи $(\rightarrow 658) 70$

Кровью блевал, кровь проливал 147

Крой с левой (Х.п.с.) 237

Кружу по маршиутам 285

Крым, лицезрение твоих (Ру) 281

Крячная, мрачная мымра 116

Кто во что, а я поэт $(\rightarrow 314)$ (X.n.c.) 26

Кто вы? (Х.п.с.) 36

Кто за Фишера? 118

Кто помнил (Ру, Х.n.c.) 131

Кто скажет, где, когда 169

Кто там? Ах, это ты 155

Кто тебя нарисовал? 248

Кто это такой? (X.n.c.) 266

Кусочек Сочи (Py) 213

... латинский гений 281

Лёгкие на помине (X.n.c.) 97

Лёгкость в мыслях (Ру, Х.п.c.) 202

Лежу и думаю (Рy, Х.n.c.) 211

Ленин был великий 180

Лесенка $(\rightarrow 588) 19$

Летите, голуби, летите (X.n.c.) 80

Лето кончается на песке 259

„Лето! Это! Хорошо!" (Py, X.n.c.) 257

Ликуй, Исайя, голоси (X.п.c.) 252

Листья падают (X.n.c.) 271

Лошадь промчалась (X.n.c.) 292

Луна сегодня подрумяненная 112 
Лунная ночь глубока (X.п.с.) 271

Любить... молиться 278

Люблю стихи (Х.п.с.) 142

Люблю толпиться $(\rightarrow 517)$ (Ру, Х.п.c.) 86

Любовь... / Предаю по буквам 148

Любовь, бессоница, аптека 255

Люди знахомые нам (X.п.с.) 293

Люди приготовились х зиме 172

Людка-Милка 13

Магнитное поле сирени 253

... маленькая голова 64

Маленький мальчик 243

Мальчики (Х.п.c.) 179

Мальчишкой я подхалтуривал 184

Мама, мама, / когда (Py, X.п.c.) 150

Мама / улыбнулась на ребёнка 117

Март меня не радует 205

Мартовские недоделки ( $\rightarrow 14$ ) (Ру) 148

Маска выросла на лице 298

Межиров 249

Меньше всего я хочу загадывать 143

Местные жительницы и жители 254

Метисы от евреев очень хороши 59

Мирной жизни радуюсь вдвойне 141

Миру мир ( $\rightarrow 213)$ (Х.п.с.) 41

Мне говорят ( $\rightarrow$ Дык...) (X.n.c.) 58

Мне и хочется, и не хочется 251

Мне надо забыть (Ру) 132

Мне нравится Рита Паперная 236

Мне нравится эта (Ру, Х.п.c.) 36

Мне снилось: я еду на грузовике 26

Mногогорье 265

Моё - не моё $(\rightarrow 25)$ (Pу, X.п.с.) 47

Моё тихоюбилейное (Х.п.с.) 35

Может быть (X.п.с.) 191

Мой язык славянский (X.п.c.) 60

Молодые дамы 40

Молчать не надо 298

Море - и небо (Ру) 194

Моя последняя $(\rightarrow 726)$ (X.n.c.) 86

Мужественно (Ру, Х.п.с.) 23

Мутный день (X.п.c.) 287

Муха влетела в окно (Х.п.с.) 109

Мхи и пальмы 175

Мы были здесь осенью (X.п.с.) 51

Мы незваные гости (X.n.c.) 211

Мы пошили чехлы 252

Мы сидели у Айги./Вы (Рy, Х.n.c.) 64

Мы сидели у Айги./Я (Ру, Х.п.с.) 246

Мы уже были за Саном 112

Мыши и кот (Х.п.c.) 219

... мякоть парного (Pу, X.п.c.) 273

Мяло 221
На Бобика Заходера 264

На Ваганьковском 276

На войне как на войне (Рy) 178

На всё удивляются 146

Ha дороге 216

... на ихнем знамени 272

На холокольне завыл петух (Ру) 203

На носу дека6рь (X.n.c.) 200

На одной струне 213

На помидорах (Ру, Х.п.c.) 68

На пыльных улицах 173

На сетчатке глаз 215

На старости лет 173

На улице 228

На цветной фотографии 210

Наверное, оттого (Ру) 161

Надоела Земля и Воля 231

Надпись на книге 260

Надпись на „Сестре моей..." 264

Надпись на спичечной коробке 55

Назвали Ильёй 217

... нахонец-то (X.n.c.) 256

Налево от меня - сам Гныч (Ру) 162

... наука - сука (X.n.c.) 81

Наука умеет много гитик 271

Начало я проспал (Ру, Х.п.c.) 160

Háw xадp, - aлxaw 57

Hawa 6epër! 138

Нашей улицей ветер овладел 182

Не в среду... может быть 297

Не волынь, угомонись 298

НЕ ВСЁ ПРОПАЛО (Х.n.c.) 245

Не говорите мне (X.n.c.) 77

Не замазывайте мне (Py, X.п.c.) 122

Не оттого ли нынче день хорош 167

Не слышно ржущих голосов 129

Не спит, до поздней ночи 177

Не стой с задумчивым видом 266

Не тахая большая потеря 257

... не только в Абхазии 260

Не троньте 222

Не увижу 239

Не умею по-тарабарски 177

Не шапируйте их 97

Не Шостакович (X.n.c.) 82

Не6о, синее как зяблик 236

Недавно тили-лили (Х.п.c.) 103

Незаменимых нет (X.п.c.) 129

Нехрасов, а, Нехрасов! 85

Неохота мне больше ишачить 134

Неправда, она не меняется (Ру) 180

Неправильно тебя, парень (Ру) 217

Нет, Марцинковский (Рy, Х.n.c.) 113

Нет, не смешно $(\rightarrow 51) 150$

Нет, не то, (Py, X.n.c.) 50 
Нет никого на свете (Ру, Х.п.с.) 203 Нечего сказать 241

Ни кустов 178

Ни малейшего (X.n.c.) 98

Ни на русого (Ру, Х.п.c.) 188

„Ник. Котенко“" - ник-то (Ру) 130

Никак не запомню (Py, X.n.c.) 87

Никонов, староста 260

Ничего не 6олит (Х.п.с.) 289

Но разве мыслили мы 47

Ночной фиалкой тянет с луга 166

Ну, вот и дорбга 99

Ну и редкое выдалось 296

Ну, ладно, семь бед (X.n.c.) 93

... ну процай покедова 64

\section{O Бpexte 53 \\ O как ты (Рy, X.n.c.) 25 \\ O ком я поведу рассказ? (X.n.c.) 216 \\ O, море, море 58 \\ O, трепет юности (Py, X.п.c.) 63 \\ О чём мы думали? (X.п.c.) 49 \\ Обижайтесь не обижайтесь 53 \\ Обложившись подушками 168 \\ О6о всех пишу, про деда нет 219 \\ Огни над окнами (X.n.c.) 98 \\ Одеяло (X.n.c.) 140 \\ Один американец 277}

Один идейный товарищ (X.п.c.) 123

Один известный поэт (РУ, Х.п.c.) 103

Один ревизионист 145

Один схазал (X.n.c.) 155

Одна 6а6а сказала: А - Б $(\rightarrow 804) \quad 145$

Одна поэтесса сказала (X.n.c.) 100

Однажды хо мне (X.n.c.) 166

Одни говорят (X.n.c.) 251

Однофамильщы (поэма) 241-242

Оказывается, наша (Ру, Х.п.с.) 146

... оказывается, / победили 261

Олицетворённая 135

... он для красного слова 287

Он и в рифму пишет 285

Она была почти что шёлковая 51

Она лежит на спинке (Ру) 202

Она не хотела пилить (X.n.c.) 227

Oпусти глаза (Py, X.n.c.) 271

Опять понедельник (X.п.с.) 259

Опять чего-то гомонят (X.n.c.) 34

Орган слуха $(\rightarrow 113) 130$

Орудия человеколюбия $(\rightarrow 123) 64$

Осень-то (Py, X.n.c.) 178

Осторожно (Py, X.n.c.) 22

Остосвинел язых (Py, Х.n.c.) 135

Осыпаются 239

От Ерунаии до Мерехлюндии 37
Oт картофельного поля (Х.и.с.) 277

Отвоевался, отвоевал 299

Отвяжись, не вой, на 156

Отгремели, как говорится 209

Отдам азим коду (Ру, Х.п.c.) 99

Отит $(\rightarrow 600) 33$

Откуда эта мелкодраматическая 233

Отстал (Х.п.c.) 180

Oтхаркнув, нсследую мокрбту 31

Отцепись от меня (X.n.c.) 204

Отчего 223

Ох и наломило 67

Ох, и пополито нашей хровушки 158

Ох и славно до чего 13

Oх, какой мужик прездоровый 171

Память войны-ыыы $(\rightarrow 23) 29$

Пара романсов (X.n.c.) 262

Парень, тюха-матюха (Ру, Х.п.с.) 120

Перевожу Винграновского 288

Перед глазами стена (Ру) 184

Перед 67 днём рождения 296

Перепутались в голове (X.п.c.) 274

Пересвонлась (Ру, Х.п.c.) 88

... переталдыкивают 256

Перечитываю снова (X.n.c.) 24

Писем нету 158

ГІисьма до востребования 18

Пинуу стихи 32

Платоновское / Kaх $(\rightarrow 620) 31$

Платоновское / Не слышно 129

... плюс отрицательные эмоции 274

По радио - военачальники 40

Побывал я в Польше 204

Поговорим с тобой $(\rightarrow 610)$ (Х.п.с.) 17

Под ногами, спбря (Ру) 295

Подумал, что это ничто иное 291

Позвонил соседу (Ру) 23

... пока нас не выселили 273

Поха не меряешь давления 284

Покойный Володя Бугаевский 256

Полегоньку дышу 223

Полетели письма, тю-тю $(\rightarrow 484) 112$

Половой вопрос (Х.п.с.) 210

Полюби меня, русская 6а6а $(\rightarrow 613) 52$

Полюбил я последнее время (Ру) 134

Помню ЛЩК $(\rightarrow 417)$ (Ру, Х.п.с.) 122

Пора, пора писать (Ру, Х.п.с.) 197

Поселок Волошина (Ру, Х.п.c.) 265

Посещение А.E.Кручёных (X.n.c.) 18

После дождя 263

После побелки (Ру, Х.п.с.) 63

... послушать радио, что-ли 300

Посолонйда (X.n.c.) 54

Постигнув 248 
Постоим на бульваре 288

Потерявши невинность (Ру) 119

Потянуло апрелем 167

Похожа на Лёльку Шувалову 152

Похожий на Былинова 282

По-чешски „жизнь“ $(\rightarrow 324) 139$

Пошёл в магазин 301

Поэзия / Я вам говорю (X.п.c.) 129

Поэзия гиблое дело $(\rightarrow 83) 28$

Поэзия - не (Рy, X.n.c.) 89

Поэзия - это то 21

Появилась онкологша (X.п.c.) 296

Право, браво 255

Представь себе $(\rightarrow 250)$ (Ру, Х.п.с.) 126

Предыстория III $(\rightarrow 20)$ III

Прелестная утренняя (Ру, Х.П.с.) 281

Преступление (X.п.c.) 60

Приветствую вас, элигончики 230

Приезжаем в Харьков 159

Признак, известный (Ру) 196

Прикажите Кожевникову (X.n.c.) 249

Приснилась мне (X.n.c.) 187

Приснились (Ру, Х.п.с.) 57

Пришвинское $(\rightarrow 14) 148$

Пришёл Илюшка (Ру, Х.п.с.) 219

Пришёл ко мне (Py, Х.п.c.) 95

Пришёл рыбак (PY, X.n.c.) 77

Продолговатое тело 247

Просматриваю девушек (X.п.c.) 52

Проснулся рано (X.n.c.) 244

Прости Господи 177

Простота стиха 84

Просыпаешься среди ночи (Х.П.с.) 100

Противна мне твоя Америха 174

Протягиваю руку (Ру, Х.п.с.) 61

Проходя мимо памятника 283

Прощай, год 73-ий 249

... птиц не сльшно боле 285

Пустые стоят коровники (Х.п.c.) 187

... пусть ликует стар и млад! 264

Пусть победить слабейший (Ру) 292

Пусть стал я как мощи (X.n.c.) 45

Пью 56

Рабин: бараки, сараи (X.п.c.) 23

Радуюсь только цветам (Х.п.c.) 244

Раз ! - и в дамки 247

Разучившись мыслить (Ру, Х.п.c.) 130

Рано пошабашили (X.n.c.) 80

Paccka3 (X.n.c.) 141

Рассказать вам всё? (Py, X.n.c.) 200

Рассказать вам про случай (Ру) 187

... расстрелян Николай (X.п.с.) 291

Растрёпанный неряха 17

Реальное яблочко изобразить 136
Ребёнок рисунка (РУ, Х.П.с.) 66

... РE3AЛ ЛА3EP 256

Рецензия на поэмы (X.n.c.) 34

Рецензия на стихи $(\rightarrow 652) 51$

Решаю ребусы Бориса Пастернака 269

Ржавые овцы 220

Рифмую то, рифмую сё 300

Родияся на чужбине 147

Родятся звуки (Ру, Х.п.c.) 267

... роз не коснусь (РУ, Х.п.c.) 265

Розовый $\rightarrow 588) 19$

Романс / Русская женщина 33

Романс / Ещё вращается 30

Рукописи его (Pу, Х.п.c.) 226

Румяная, рослая, русая 170

Русская женщина только 33

Русские по-турецки (Ру, Х.п.с.) 235

Рыбы дышат жабрами (X.n.c.) 104

С каждым днём (X.п.с.) 290

... с кем сегодня состыкуемся 263

С мычащими мальчишками 227

С трудом (Ру, Х.n.c.) 110

... с утра так радостно (Ру, X.п.c.) 266

Савва, помню (Pу, X.п.c.) 106

Cаwка Попов (X.n.c.) 163

Свет неясный (X.п.c.) 286

... светает, слава Богу! 279

Светлые 35

Свивались, бились 280

"Свободу" надо (Х.л.с.) 35

Своим потайным фонариком 186

Сегодня 17-ое июня (Рy, Х.n.c.) 111

Сегодняшний день 292

Сейчас, не очень $(\rightarrow 200)$ (Ру, Х.п.с.) 45

Секс-бобма Мэри (Ру, Х.п.с.) 172

Село Новосёловка (Ру, Х.п.с.) 267

... семнадцатое, девятнадцатое 286

Серо-зелёное зло (Ру) 69

Сидел в читальне 304

Сиена жжёная, цвет ожога 78

Симанович-старик (Ру, Х.п.с.) 229

Сколько погибло цветов! 147

Сколько ушло (Х.п.с.) 103

Скуда взято $(\rightarrow 643) 102$

Слова (Ру, Х.п.с.) 29

Слова-то какие: кортеж (Х.п.с.) 50

Случнлось непонятное 181

Слушай сказку, детка (X.п.c.) 97

Смотрюсь в это (Ру, Х.п.с.) 234

Снабженцу 88

Снег идёт (Ру) 22

Снег с утра 179

Снегурочка! (Pу, X.n.c.) 236

Снится девушке (РУ, Х.п.с.) 281 
Солнце - открылось $(\rightarrow 10.4 .68) 62$

Солодкий Иисус, явись (Ру) 267

Cпаси6о пане Павлу (Х.п.с.) 37

Спросите их, спросите (X.п.с.) 176

Стакан томатного сока (X.п.c.) 211

Старый голубь, похожий (Х.п.с.) 29)

Старый город (Ру) 183

Стихи! Стихи! 123

Стихотворение называется 148

Стою перед дверью (Х.n.c.) 143

Стукачи (X.n.c.) 61

Судом Истории (Ру) 29

Сутин я, или Сутин $(\rightarrow 606) 132$

Схлестнулись с лириками 105

... сядет на страницу 245

Сялу, радио ( $\rightarrow$ 45) (X.n.c.) 125

Та в Aхтырке 306

Так 6ыло, так будет (Ру) 293

Tax 6ыстро (X.n.c.) 105

Tак вот чего нам (Py, X.n.c.) 285

Tак, ничего (Py, X.n.c.) 41

Tak что же - стать (X.n.c.) 92

Тахая славная пора (Py, X.n.c.) 272

Таких, как ты, на свете много 170

теперь из ссылки 282

... теперь поллитра не говорят 258

Тихий голос, слышный всякому 39

То есть, до чего (X.n.c.) 110

Товарищ, а, товарищ 66

Толкнула меня грудью 168

Трави, трави, затворник 301

Требуются способные (X.n.c.) 199

Тухачевский? 275

Ты, вечно хныкающий 32

Ты, вша партийная (X.n.c.) 258

Ты говорншь 30

Ты книжечку перелистал 254

ты, мастер спорта 276

Ты стал сатира и умора (X.n.c.) 1.38

Тюмень, да тёща (X.n.c.) 201

Тютчев 87

У всех энакомых 116

У двушкина две руки (X.n.c.) 247

У Истории $(\rightarrow 430) 65$

У, ках сыро и хмуро (Ру) 224

У меня - отличное (X.n.c.) 152

У нас был примус (Py, X.n.c.) 155

У сердечников дурная память (Ру) 157

У тебя в груди передвигали шкаф 31

У часового я спросил (РУ, Х.n.c.) 54

У Зммы Зфраимовны $(\rightarrow 652) 51$

Уважаемые дамы и господа 94

Увидел ча́чек, обрадовался 63
Увояли 60 6ягули карчуна́ 71

Угадайте, что бывает (X.n.c.) 238

Удивляетесь (Ру, Х.п.с.) 237

Уж не я ли 24

Уже час, по нашему два $(\rightarrow 10)$ (Ру) 48

Улитка, улитка (X.л.с.) 147

Улицы со ступеньками (Ру, Х.п.с.) 210

... ультра + порно 286

Умер Додя, 84 года (Ру, X.n.c.) 217

Умер старнк (Ру) 243

Умер старый король 240

Умолкает ветер 302

Уничтожаю (X.n.c.) 90

Ускорение сил старости 238

Утречком 277

Утро 212

Утром солнце (Pу, Х.n.c.) 141

Ух ты, вот это да! (Рy) 224

Уила на базу (Ру) 288

Фальшь - гугумани зм (Ру) 28

Физики 224

.. философ Анри Бергсон умер 270

Фонари, светящие (X.n.c.) 284

Ха и Вэ (Ру, Х.n.c.) 222

Ха, ты еще не умер $(\rightarrow 193)$ (Х.п.с.) 124

Характеристика на еврея (X.n.c.) 288

Хіба ревуть воли 297

Хмурый денёк (Pу, Х.n.c.) 288

Ходит слесарь по ремонту 159

Хожу, дышу морем 205

Хожу по Проспекту, любуюсь 246

Холин искал себя на Марсе 34

Хорошая 6аба: высокая (Ру) 195

Хорошенькая официанточка 169

... хорошо 6ы мерку (Рy, Х.п.c.) 270

Хорошо в Москве 84

Хорошо глазам в саду (X.n.c.) 283

Хочется написать (Ру) 70

Хочу в город 158

Хочу ли я посмертной (Ру, Х.п.c.) 101

Христианин (Х.п.с.) 99

Художник Володя Яковлев (Х.п.c.) 110

Целый день 235

Часто ли я нзменяю жене 174

Человек, которого я обидел (Ру) 170

Человеколиния (Ру, Х.п.с.) 236

Человек-человеку-внук 116

Чем больше ты меня шпыняешь 137

Чем дальше х старости (X.n.c.) 122

Черноморское побережье 233

Чёрт побери 47 
Чертёжник мильй (X.n.c.) 216

Четыре года земля качалась 160

14 апреля (Х.л.с.) 94

Читатель - чего он хочет? 226

Читаю назидания Абая 44

... что весенняя осень 287

Чго ж нам делать (Х.II.c.) 35

... что не в Стравинских (X.n.c.) 14.3

Что-то знакомое (Ру, Х.n.c.) 127

Чго ты вякаешь (Рy, X.n.c.) 218

Что это значит? ( $\rightarrow 682)$ (Py, X.n.c.) 96

Что я вам оставляю? (X.n.c.) 238

Что я вижу? (Ру, Х.n.c.) 208

Что я, ненормальный, что ли 296

Чулаки! - зачем вам дразнить их 85

Чудной денёк! 109

Чужая, чужая, чужая (X.n.c.) 185

Чужие слюни, слёзы, сопли 46

Чукоша, кокоша 294

Чумацкий шлях (Ру) 268

Чуть в полусне паутинку 286

Чьё-то дыханье 128

Шаламовское (X.n.c.) 21

Шесть дней вкалывай 14

Шёл, нашёл золотник $(\rightarrow 631) 71$

Шёл пешеход (X.n.c.) 264

Шолом алейхем, Шарм аш Шейх 240

Шумыко сказал (Ру) 223

Щит 186

\section{3ท̀ 276}

Зкспрессионизм-сионизм (X.n.c.) 207

Зник, Беник, именинник 300

ॐитафия 145

Эта видимость смысла (Py, X.п.c.) 220

Эra девушка 245

Эии на тех, те на этих 302

Это немыслимо (X.n.c.) 50

Это уже не кошки-мышки $(\rightarrow 604) 16$

Эоо-я-и не я (Ру) 201

Это я, на мусорном ящике 205

Этого я не пойму 212

Эу девушку или женщину 243

3x, Мандельштам (X.n.c.) 67

$3 x$, tëk, tëk, tëk 305
Юность 140

Я был из тех (X.n.c.) 92

Я вам I оворю (X.n.c.) 129

Я верю только в труд 56

Я, / всё-таки 145

Я живу на старом месте 175

Я завёл себе забаву - от скуки 126

Я завидую Вам 189

Я иду домой 287

Я из Беккета. Я Гого 225

Я их не не ненавилел $(\rightarrow 75) 44$

Я как лурак в леревне (X.n.c.) 42

Я лсжу животом на гальке 212

Я лежу, закрыв глаза 262

Я любил одну (X.n.c.) 127

Я людей не перевариваю 66

Я Мойша $(\rightarrow 657)$ (Рy, Х.n.c.) 144

Я не люблю всезнающих 128

Я не поэт (X.n.c.) 231

Я не против реализма (Х.I.c.) 194

Я не хочу воевать 175

Я не хочу всё знать 27

Я не член ни чето (Ру, Х.ा.с.) 293

Я отторажнваюсь от вас 2.32

Я- noю, 自 - nofo (Py) 202

Я рифмую дождь и плащ 113

Я рядом с Ялтой, в Кастро́nоле 18.3

Я сетодня - только вышел 118

Я теперь по ночам в „Феолосии“ 279

Я теперь работаю (Рy, Х.n.c.) 104

Я теперь стал регулярно $(\rightarrow 4) 137$

Я гоже думал 1.35

Я - трус, трус, трус (X.n.c.) 206

Я, ты, он (Py, X.n.c.) 198

... я уважаю Вашу работу (X.n.c.) 249

Я уеду, как приехал (X.n.c.) 157

Я уже не школьник 260

Я умираю 72-74

Я услышал во сне элегию Массне 258

Я хорошо, я плохо жил (Х.n.c.) 99

Я хотел бы писать (Х.n.c.) 263

Я хочу написать (X.n.c.) 277

Я чужой тебе (X.n.c.) 94

Ялта (X.п.c.) 235

Январь, февраль (Ру, Х.п.с.) 294 


\section{ПРИМЕЧАНИЯ ИЗДАТЕЛЯ}

1. Вопросительные знаки после указания года или даты взяты из оригинала. Если они поставлены в квадратиые скобки, то они добавлены издателем.

2. В некоторых стихотворениях Сатуновский нолзовался ранее нанисанными текстами. Если он для этого сослинил два прежних стихотворсиия (ср. его примечание на стр. 274), то в реестре ссылается на все гри нарианта. Как правило Сатуновский сохранил только последний, соединенный віриант. 
A R B E ITEN U N D TEXTE Z UR SLA VIS T IK HERAUSGEGEBEN VON WOLFGANG KASACK

1 Sabine Appel: Jurij Olesa "Zavist" * und "Zagovor cuvstv « Ein Vergleich des Romans mit seiner dramatisierten Fassung. 1973. 234 S. DM 24.-

2 Renate Menge-Verbeeck: Nullsuffix und Nullsuffigierung im Russischen. Zur Theorie der Wortbildung. 1973. IV, 178 S. DM 18.-

3 Jozef Mistrik: Exakte Typologie von Texten. 1973. 157 S. vergriffen

4 Andrea Hermann: Zum Deutschlandbild der nichtmarxistischen Sozialisten. Analyse der Zeitschrift "Russkoe Bogatstvo * von 1880 bis 1904. 1974. 198 S. DM 20.-

5 Aleksandr Vvedenskij: Izbrannoe. Herausgegeben und eingeleitet von Wolfgang Kasack. 1974. 116 S. vergriffen

6 Volker Levin: Das Groteske in Michail Bulgakovs Prosa mit einem Exkurs zu A.Sinjavskij. 1975. $158 \mathrm{~S}$. vergriffen

7 Геннадий Айги: Стихи 1954-1971. Редакция и вступительная статья В.Казака. 1975. $214 \mathrm{~S}$. vergriffen

8 Владимир Казаков: Ошибка живых. Роман. 1976. 201 S. vergriffen

9 Hans-Joachim Dreyer: Pëtr Veršigora "Ljudi s cistoj sovest' ju « Veränderungen eines Partisanenromans unter dem Einfluß der Politik. 1976. 101 S. DM 15.-

10 Николай Эрдман: Мандат. Пьеса в трех действиях. Редакция и вступительная статья В. Казака. 1976. 109 S. DM 15.-

11 Karl-Dieter van Ackern: Bulat Okudžava und die kritische Literatur über den Krieg. 1976. 196 S. DM 20.-

12 Михаил Булгаков: Ранняя неизданная проза. Составление и предисловие $\Phi$. Левина. 1976. 215 S. DM 24.-

13 Eva-Maria Fiedler-Stolz: Ol'ga Berggol'c. Aspekte ihres lyrischen Werkes. 1977. 207 S. DM 20.-

14 Christine Scholle: Das Duell in der russischen Literatur. Wandlungen und Verfall eines Ritus. 1977. 194 S. DM 20.-

15 Aleksandr Vvedenskij: Minin i Požarskij. Herausgegeben von Felix Philipp Ingold. Vorwort von Bertram Müller. 1978. 49 S. vergriffen

16 Irmgard Lorenz: Russische Jagdterminologie. Analyse des Sprachgebrauchs der Jäger. 1978. 558 S. DM 60.-

17 Владимир Казаков: Случайный воин. Стихотворения 1961-1976. Поэмы. Драмы. Очерк „Зудесникж. 1978. 214 S. vergriffen

18 Angela Martini: Erzähltechniken Leonid Nikolae vix Andree vs. 1978. 322 S. DM 30.-

19 Bertram Müller: Absurde Literatur in Rußland. Entstehung und Entwicklung. 1978. 210 S. DM 24.-

20 Михаил Булгаков: Ранняя несобранная проза. Составление Ф. Левина и Л.В. Светина. Предисловие Ф. Левина. 1978. 250 S. DM 30.- 
A R B E IT TE N U N D TEXTE Z UR SLA VIST IK HERAUSGEGEBEN VON WOLFGANG KASACK

21 Die Russische Orthodoxe Kirche in der Gegenwart. Beiträge zu einem Symposium der Deutschen Gesellschaft für Osteuropakunde. Herausgegeben von Wolfgang Kasack. 1979. $86 \mathrm{~S}$. vergriffen

22 Георгий Оболдуев: Устойчивое неравновесье. Стихи 1923-1949. Составление и подготовка текста А.Н.Терезина [Г.Айги]. Предисловие А.Н. Терезина [Г.Айги]. Послесловие В. Казака. 1979. 176 S. DM 20.-

23 Wolfgang Kasack: Die russische Literatur 1945-1976. 1980. 72 S. vergriffen (siehe ATS 28 und ATS 46)

24 Михаил Булгаков: Ранняя неизвестная проза. Составление и предисловие Ф.Левина. 1981. 254 S. DM 32.-

25 Поэт-переводчик Константин Богатырев. Друг немецкой литературы. Редактор-составитель Вольфганг Казак с участием Льва Копелева и Ефима Эткинда. 1982. 316 S. DM 34.-

26 Константин Вагинов: Собрание стихотворений. Составление, послесловие и примечания Л. Черткова. Предисловие В.Казака. 1982. $240 \mathrm{~S}$. vergriffen

27 Михаил Булгаков: Белая гвардия. Пьеса в четырех действиях. Вторая редакция пьесы "Дни Турбиных«. Подготовка текста, предисловие и примечания Лесли Милн. 1983. 152 S. DM 18.-

28 Wolfgang Kasack: Die russische Literatur 1945-1982. Mit einem Verzeichnis der Übersetzungen ins Deutsche. 1983. 120 S. DM 15.-

29 Михаил Булгаков: Забытое. Ранняя проза. Составление и предисловие $\Phi$. Левина. 1983. 140 S. DM 18.-

30 Лев Лунц: Завещание Царя. Неопубликованный киносценарий. Рассказы. Статьи. Рецензии. Письма. Некрологи. Составление и иредисловие Вольфганга Шрика. 1983. 214 S. DM 24.-

31 Lev Loseff: On the Beneficence of Censorship. Aesopian Language in Modern Russian Literature. 1984. 278 S. DM 38.-

32 Gernot Seide: Die Klöster der Russischen Orthodoxen Kirche im Ausland in Vergangenheit und Gegen wart. 1984. $196 \mathrm{~S}$. vergriffen

33 Андрей Платонов: Старик и старуха. Потерянная проза. Составление и предисловие Фолькера Левина. 1984. 216 S. DM 26.-

34 Luise Wangler: Vasilij Belov. Menschliche und gesellschaftliche Probleme in seiner Prosa. 1985. 70 S. DM 12.-

35 Wolfgang Kasack: Russische Literatur des 20. Jahrhunderts in deutscher Sprache. I. Band. 350 Kurzrezensionen von Ủbersetzungen 1976-1983. 1985. 160 S. DM 22.(siehe ATS 50) 
A R B E I T E N U N D T EX TE Z UR SLA VIST IK HERAUSGEGEBEN VON WOLFGANG KASACK

36 Владимир Линденберг (Челищев): Три дома. Автобиография 1912-1918 rг., написанная в 1920 году. Подготовка текста и послесловие Вольфганга Ка3ака. 1985. 92 S., 16 Abb. DM 16.-

37 Renate Schäper: Die Prosa V. G. Rasputins. Erzählverfahren und ethisch- religiöse Problematik. 1985. 294 S. DM 38.-

38 Wolfgang Kasack: Lexikon der russischen Literatur ab 1917. Ergänzungsband. 1986. $228 \mathrm{~S}$. vergriffen (siehe ATS 52)

39 Wolfgang Schriek: Ivan Šmelëv. Die religiöse Weltsicht und ihre dichterische Umsetzung. 1987. $321 \mathrm{~S}$., $10 \mathrm{Abb}$. DM 38.-

40 Wolfgang Kasack: Bücher - Aufsätze - Rezensionen. Vollständige Bibliographie 1952-1987, anläßlich des sechzigsten Geburtstages zusammengestellt von Irmgard Lorenz. 1987. 102 S. DM 15.-

41 Barbara Göbler. A. Adamov und A. und G. Vajner. Aspekte des sowjetischen Kriminalromans. 1987. 104 S. DM 15.-

42 Fritz Wanner: Leserlenkung, Ästhetik und Sinn in Dostoevskijs Roman Die Brüder Karamazov « 1988. 274 S. DM 38.-

43 Frank Göbler: Vladislav F. Chodasevix. Dualität und Distanz als Grundzüge seiner Lyrik. 1988. 304 S. DM 38.-

44 Tausend Jahre Russische Orthodoxe Kirche. Beiträge von Geistlichen der Russischen Orthodoxen Kirche im Ausland und Wissenschaftlern verschiedener Disziplinen. Herausgegeben von Wolfgang Kasack. 1988. 200 S. DM 28.-

45 Die geistlichen Grundlagen der Ikone. Herausgegeben von Wolfgang Kasack. 1989. 204 S., 23 Abb. DM 28.-

46 Wolfgang Kasack: Russian literature 1945-1988. Translated by Carol Sandison. 1989. 160 S., 35 Abb. DM 24.-

47 Иван Ахметьев: Миниатюры. 1990.76 S. DM 20.-

48 Christopher Hüllen: Der Tod im Werk Vladimir Nabokovs. Terra Incognita. 1990. 252 S. DM 38.-

49 Michaela Böhmig: Das russische Theater in Berlin 1919-1931. 1990. 328 S. DM 52.-

50 Wolfgang Kasack: Russische Literatur des 20. Jahrhunderts in deutscher Sprache. 2. Band: 450 Kurzrezensionen von Übersetzungen 1984-1990. 1991. 286 S. DM 45.-

51 Birgit Fuchs: Mensch, Gesellschaft und Religion im Werk Timur Pulatovs. 1992. 100 S. DM 18.-

52 Wolfgang Kasack: Lexikon der russischen Literatur des 20. Jahrhunderts. Vom Beginn des Jahrhunderts bis zum Ende der Sowjetära. 2., neu bearbeitete und wesentlich erweiterte Auflage. 1992. XVIII S., 1508 Sp. DM 98.-

53 Frank Göbler: Das Werk Aleksej Konstantinovič Tolstojs. 1992. 461 S. DM 88.- 
ARB B I T E N U N D TEX TE Z UR SLA VIST IK HERAUSGEGEBEN VON WOLFGANG KASACK

54 Сергей М.Сухопаров: Алексей Кручёных. Судьба будетлянина. Редакция и предисловие Вольфганга Казака. 1992. 166 S, 30 Abb. DM 25.-

55 Jan Paul Hinrichs: Verbannte Muse. Zehn Essays über russische Lyriker der Emigration A.Nesmelov, G.Ivanov, V.Lebedev, D.Knut, V.Lourié ,B.Poplavskij, A. Štejger, V.Perelešn, N.Moršen, I.Elagin. Ủbersetzt von Th. Hauth. 1992. 144 S. DM 24.-

56 Eberhard Reißner: Das russische Drama der achtziger Jahre. 1992. 342 S. DM 52.-

57 Daniela von Heyl: Die Prosa Konstantin Vaginovs. 1993. 111 S. DM 20.-

58 Ян Сатуновский: Рубленая проза. Собрание стихотворений. Составление, подготовка текста и предисловие Вольфганга Казака. Послесловие Геннадия Айги. 1994. 328 S., 5 Abb. DM 50.- 